\title{
BEACH AND BORROW SITE SEDIMENT INVESTIGATION FOR A BEACH NOURISHMENT AT OCEAN CITY, MARYLAND
}

by

Fred J. Anders, Mark Hansen

Coastal Engineering Research Center

DEPARTMENT OF THE ARMY

Waterways Experiment Station, Corps of Engineers

3909 Halls Ferry Road, Vicksburg, Mississippi 39180-6199

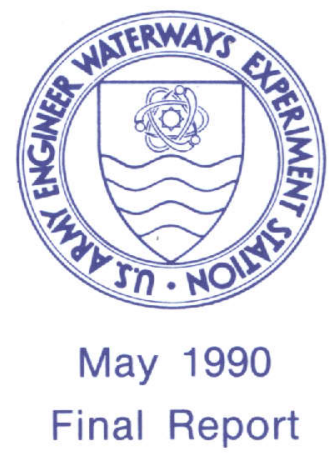

Approved For Public Release; Distribution Unlimited 
Destroy this report when no longer needed. Do not return it to the originator.

The findings in this report are not to be construed as an official Department of the Army position unless so designated by other authorized documents.

The contents of this report are not to be used for advertising, publication, or promotional purposes. Citation of trade names does not constitute an official endorsement or approval of the use of such commercial products. 
Unclassified

SECURITY CLASSIFICATION OF THIS PAGE

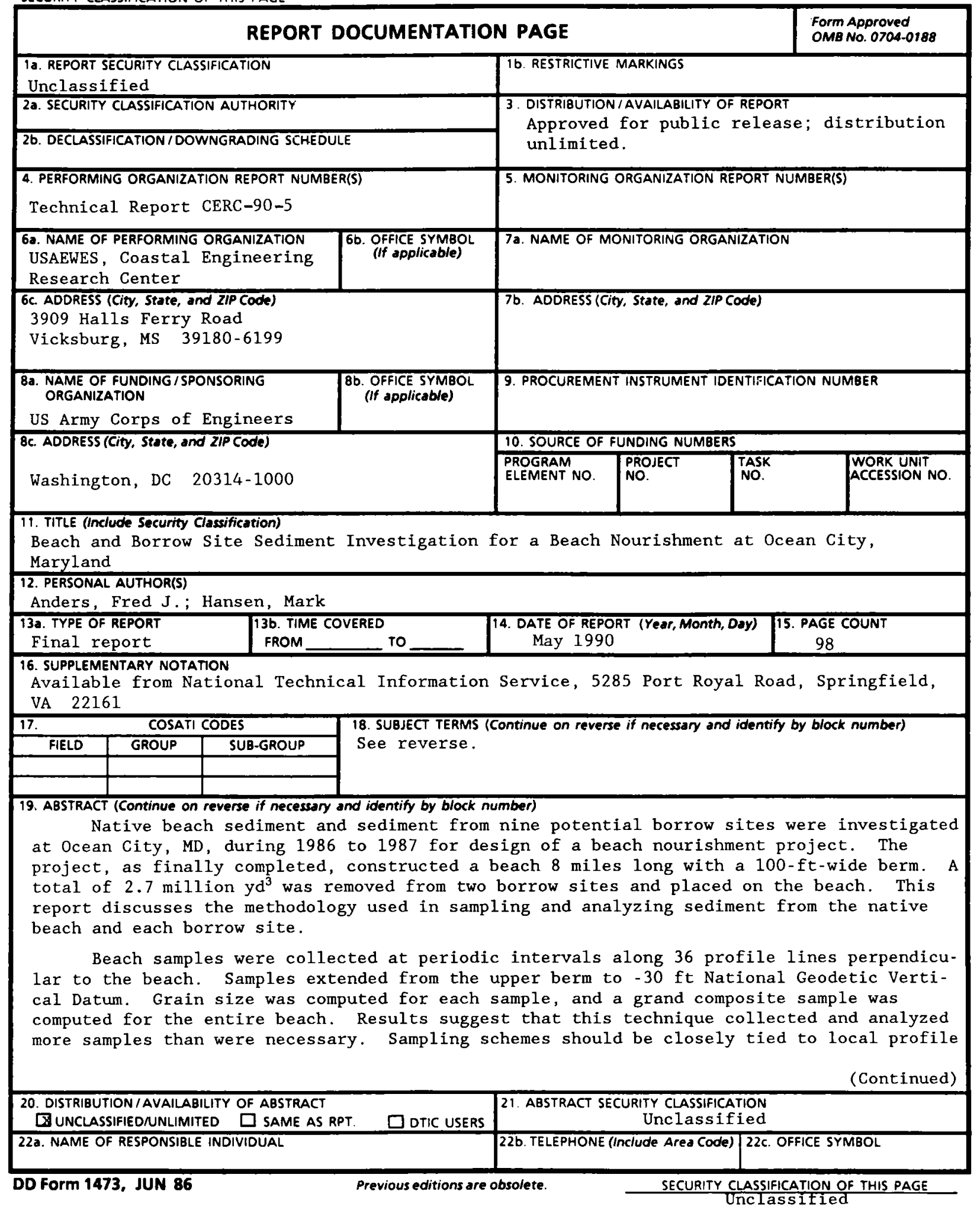


Unclassified

ITEURITY CLASEIFICATION OF THIS FAOE

18. SUBJECT TERMS (Continued).

Beach-fill design

Beach nourishment

Borrow sites

Closure

Delmarva

Linear shoals

Ocean City, MD

Overfill ratio

Sampling

Sand

Vibracores

19. ABSTRACT (Continued).

closure depth and take advantage of natural alongshore consistency in grain size. A streamlined sampling plan could also benefit the final calculated composite and improve the chance of nourishment success. Temporal changes in sediment were examined through a one-time beach coring program that sampled the entire active envelope of sediment.

Borrow sites were investigated through a combination of geophysical surveys and vibracores. Subbottom profile data were useful in locating potential coring sites. Channel samples were removed from each core, and grain size analyses were performed. Composite samples were calculated for each borrow site and compared with the native beach composite to develop overfill ratios. Data from the cores, along with environmental and political considerations, reduced the number of potential borrow sites from nine to three. The volume of acceptable material available in each borrow site was calculated and compared with the required volumes from each site. Several improvements in planning data collection and analysis are suggested to facilitate borrow site evaluation. 


\section{PREFACE}

During 1986 and early 1987, work was completed for the State of Maryland, Department of Natural Resources (DNR), on native beach sediment characteristics at Ocean City, MD, and several potential borrow sites on the adjacent continental shelf. The purpose of this investigation was to obtain information for a proposed beach nourishment project at Ocean City. Few specific guidelines exist for direction in such engineering studies. The purpose of this report is to demonstrate procedures used in the investigation so that future projects may benefit from what was learned during the course of study. As is often the case, in hindsight it is evident where field techniques and data analysis could be improved. Where possible, improvements have been suggested in this discussion. While it is the authors' intent to provide guidelines for future beach nourishment investigations, the user must keep in mind that field conditions and project requirements vary and must dictate direction of each individual study.

Field data collection and analysis were performed by the Coastal Engineering Research Center (CERC) of the US Army Engineer Waterways Experiment Station (WES). Funding for data collection and analysis and for reporting of results was provided by DNR. Funding for this report was provided by the Barrier Island Sedimentation Studies work unit of the Coastal Morphology Unit at CERC, sponsored through Headquarters, US Army Corps of Engineers (HQUSACE). Technical Monitors were Dr. C. Linwood Vincent (CERC) and Messrs. John H. Lockhart, John G. Housley, James E. Crews, and Charles W. Hummer, HQUSACE.

This report was prepared by Messrs. Fred J. Anders and Mark E. Hansen, CERC. The work was carried out originally under the general supervision of Dr. Suzette Kimball and later Dr. Donald D. Stauble, Chief, Coastal Morphology Unit, CERC; Dr. Stephen A. Hughes, Chief, Coastal Processes Branch, CERC; Ms. Joan Pope, Chief, Coastal Structures and Evaluation Branch, CERC; Mr. H. Lee Butler, Chief, Coastal Research Division, CERC; Mr. Thomas W. Richardson, Chief, Engineering Development Division, CERC; and Dr. James R. Houston, Chief, CERC.

Commander and Director of WES during publication of this report was COL Larry B. Fulton, EN. Technical Director was Dr. Robert W. Whalin. 


\section{CONTENTS}

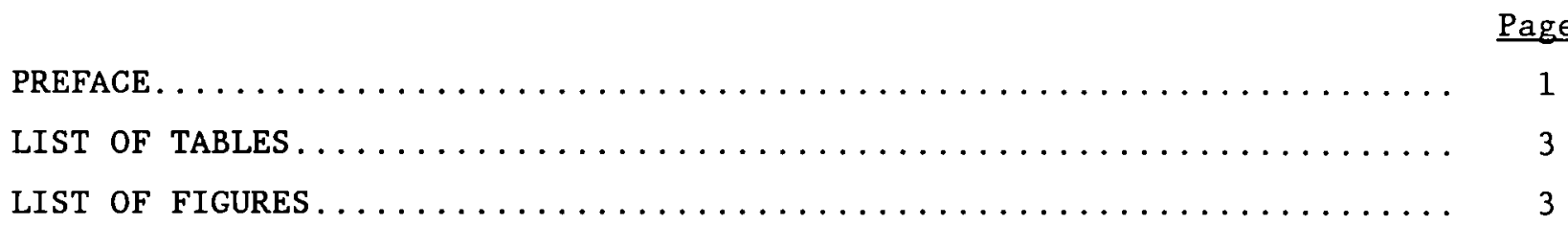

CONVERSION FACTORS, NON-SI TO SI (METRIC)

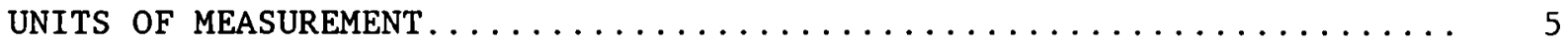

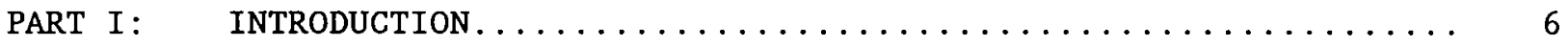

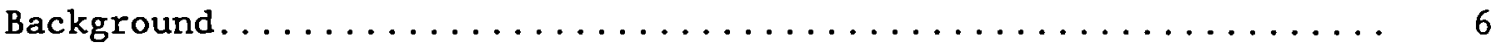

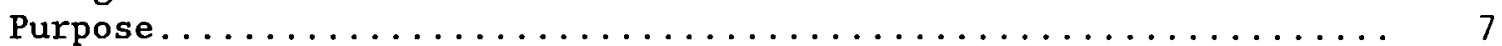

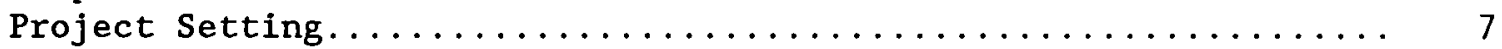

Beach Nourishment Guidelines......................... 13

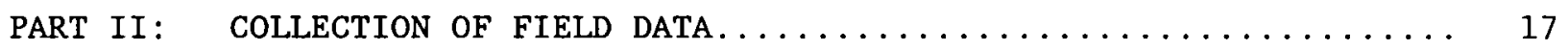

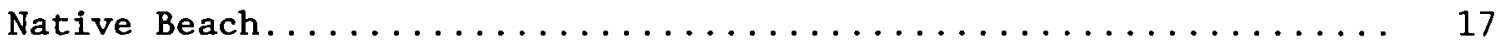

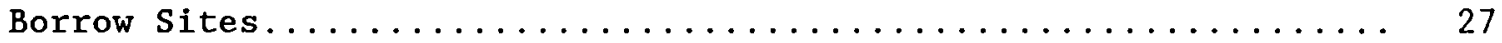

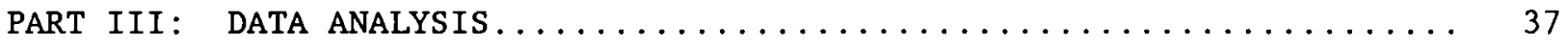

Laboratory Analysis. . . . . . . . . . . . . . . . . . . . . . 37

Analysis of Laboratory Data......................... 41

PART IV: FILL VOLUMES AND BORROW SITE SELECTION.............. 60

Determination of Required Fill Volume.................. 60

Calculation of overfill Factors..................... 66

Volume of Usable Material.......................... 71

Borrow Site Selection........................... 73

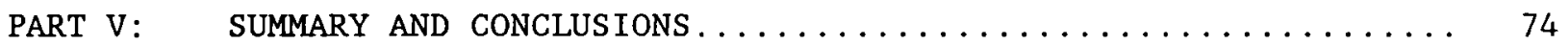

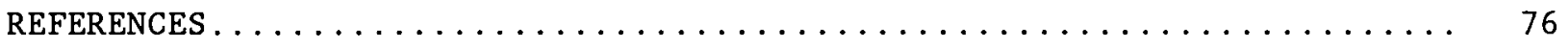

APPENDIX A: SUMMARY OF NATIVE BEACH SEDIMENT ANALYSIS..................

APPENDIX B: SUMMARY OF BORROW SITE SEDIMENT ANALYSIS .................. B1

APPENDIX C: HYDROGRAPHIC SURVEY EXAMPLES OF BORROW SITE 2 WITH 5-FT CONTOURS AND DREDGING LIMITS................. Cl 
1 Number of Samples Required to Determine Mean Grain Size of Beach to Within 0.25 phi Accuracy at Given Levels of Confidence......

Core and Borrow Site Data........................ 35

Summary of Vibracore Analysis for Borrow Site $1 \ldots \ldots \ldots \ldots \ldots \ldots .44$

Summary of Vibracore Analysis for Borrow Site $2 \ldots \ldots \ldots \ldots \ldots \ldots \ldots 47$

Summary of Vibracore Analysis for Borrow Site $3 \ldots \ldots \ldots \ldots \ldots \ldots 48$

Summary of Vibracore Analysis for Borrow site $4 \ldots \ldots \ldots \ldots \ldots \ldots \ldots$

Comparison of Mean Grain Sizes for the Entire Sand Unit and an

Upper Layer of Sand in the Cores................... 51

Summary of Vibracore Analysis for Borrow Site $6 \ldots \ldots \ldots \ldots \ldots \ldots \ldots 2$

Summary of Vibracore Analysis for Borrow Site $7 \ldots \ldots \ldots \ldots \ldots \ldots \ldots$

Summary of Vibracore Analysis for Borrow Site $8 \ldots \ldots \ldots \ldots \ldots \ldots \ldots$

Summary of Vibracore Analysis for Borrow Site $9 \ldots \ldots \ldots \ldots \ldots \ldots .54$

Percent Weight of Sediment Retained on Each Sieve for Five

Hypothetical Cores Through a Shoal Slice.............. 56

Composite Samples Calculated from Core Data................ 58

Volume Required Per Profile and Cell Volume, Scenario 3......... 64

Examination of Borrow Site Sediments by Slice............... 68

Data Summary for Selected Borrow Sites................. 72

\section{LIST OF FIGURES}

1 Location of the Ocean City field site along the Fenwick Island,

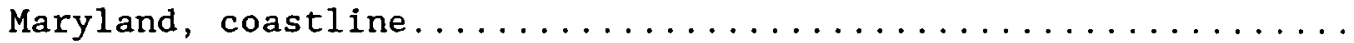
Wave Information Study (WIS) 20-year hindcast wave rose for

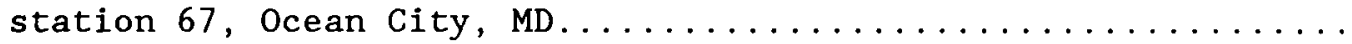
Hindcast monthly significant wave heights at Ocean City, MD, from

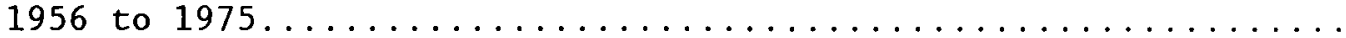
Location of shoals/potential borrow sites at Ocean City, MD......

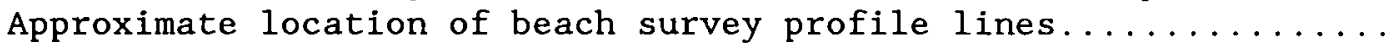
Location of sediment samples along the profile............. Comparison of mean grain size along beach transects obtained from surface and core samples.......................

Example of seasonal envelope developed from profile change data

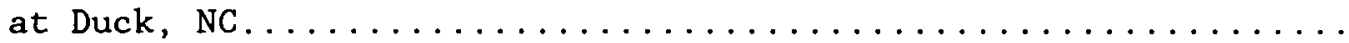

Yearly variation of calculated closure depth at Ocean City.......

Approximate location of geophysical track lines................

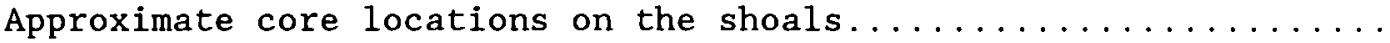
Hypothetical shoal cross section showing core locations for

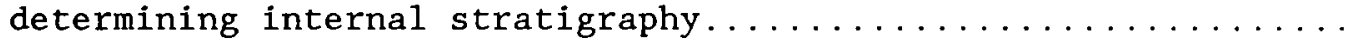

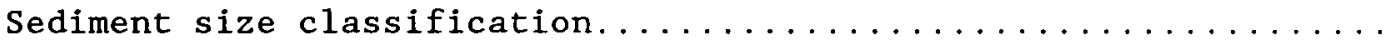

Subbottom profile record from the potential borrow sites........

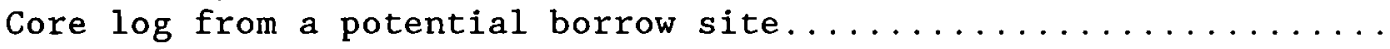
Isopach map of sand thickness in shoal/borrow site $1 \ldots \ldots \ldots \ldots$. Hypothetical shoal map with irregular core locations............. Hypothetical shoal map with evenly spaced core locations......... 


\section{LIST OF FIGURES (Continued)}

No.

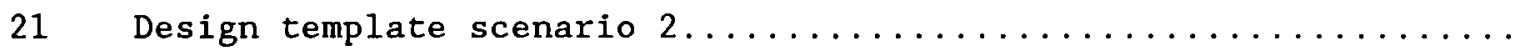

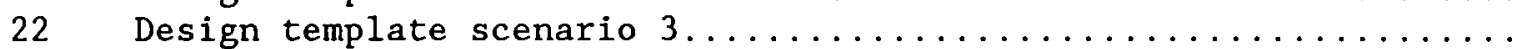

23 Translation of equilibrium profile seaward to calculate fill

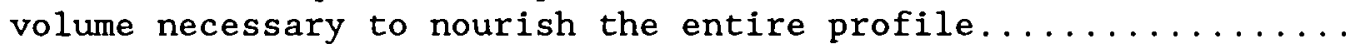


Non-SI units of measurement used in this report can be converted to SI (metric) units as follows:

Multiply

cubic feet

cubic yards

degrees (angle)

feet

inches

miles (US nautical)

miles (US statute)

ounces (US fluid)

pounds (force) per square inch

square feet

square inches

$\frac{1}{\text { By }}$
0.02831685
0.7645549
0.01745329
0.3048
25.4
1.852
1.609347
0.02957353
6.894757
0.09290304
6.4516

To Obtain

cubic metres

cubic metres

radians

metres

millimetres

kilometres

kilometres

cubic decimetres

kilopascals

square metres

square centimetres 
BEACH AND BORROW SITE SEDIMENT INVESTIGATION FOR A BEACH

NOURISHMENT AT OCEAN CITY, MARYLAND

\section{PART I: INTRODUCTION}

\section{Background}

1. Severe erosion along the Maryland Atlantic Coast prompted the US Army Engineer District, Baltimore (NAB), to investigate several methods of beach protection for this shoreline during the 1960's. Erosion at Ocean City, MD, an area of intense development, led to examination of beach nourishment as a protection measure. The State of Maryland, Department of Natural Resources (DNR), in anticipation of a Federal shoreline protection project, began scientific investigations in 1986 for construction of a recreational beach extending approximately 8 miles* along the Ocean City shoreline. The US Army Corps of Engineers (CE) proposed Atlantic Coast Beach Protection Project would add 100-year storm protection to this beach at a later date.

2. In a Memorandum of Agreement (MOA) between the State of Maryland, DNR, and the Coastal Engineering Research Center (CERC), US Army Engineer Waterways Experiment Station (WES), it was agreed CERC would examine the beach and potential borrow sites at Ocean City, MD, for the planned recreational beach nourishment project. Specifically, CERC would collect and evaluate native beach sediment to determine grain sizes and collect sediment cores and geophysical information on potential borrow sites for determination of sediment size, thickness, and lateral extent. The CERC would identify suitable borrow sources, calculate their overfill ratios, make borrow site recommendations, and after consultation with DNR, develop cross-section design templates for the actual beach fill. Field sampling and profiling of the native beach began in April of 1986. Collection of cores from potential borrow sites took place in August and November. Sediment analysis was completed, and a final report was submitted to DNR in June 1987, approximately 1 year from signing of the MOA.

* A table of factors for converting non-SI units of measurement to SI (metric) units is presented on page 5. 


\section{Purpose}

3. This report includes procedures CERC used in planning field work, data collection, data analysis, and developing site recommendations. Alternative procedures are also discussed along with recommendations for improving similar studies in the future. Results presented for Ocean City serve as one example of the kind of information necessary for effective planning of a beach nourishment project.

\section{Project Setting}

4. Ocean City, MD, is centrally located along the Delaware-MarylandVirginia (Delmarva) peninsula coast, on Fenwick Island, a naturally occurring barrier spit backed by Isle of Wight and Assawoman Bays (Figure 1). Ocean City Inlet forms the southern boundary of Fenwick Island. It was created naturally during a hurricane in 1933 (Truitt 1968). During the late 1920's, artificial inlet construction had been planned for an area approximately 3 miles south of this location to support local commercial fishing. When the new inlet opened, these plans were dropped, and jetty construction to stabilize the new inlet began almost immediately. Construction of two jetties was completed in 1935 (Knowles and Byrnes, in preparation). Inlet creation and jetty construction profoundly affected the predominantly southerly littoral drift. Updrift accretion widened the southern tip of Fenwick Island, requiring lengthening of the north jetty. A large ebb-tidal delta developed in the nearshore zone. This delta increased in size from 1933 to the present by trapping littoral sediment. The result downdrift has been rapid landward migration of northern Assateague Island (Leatherman 1979).

Erosion

5. Delmarva's coastline has undergone steady landward transgression during recent geological history as a result of sea-level rise and dwindling sediment supply (Kraft 1971; Belknap and Kraft 1977; Rice, Niedoroda, and Pratt 1976; Dolan, Hayden, and Jones 1979; Leatherman, Rice, and Goldsmith 1982; Knowles and Byrnes, in preparation). Delmarva barriers have been preserved by migrating landward under these conditions through a natural process of barrier rollover. As the shoreline erodes due to sediment loss and 


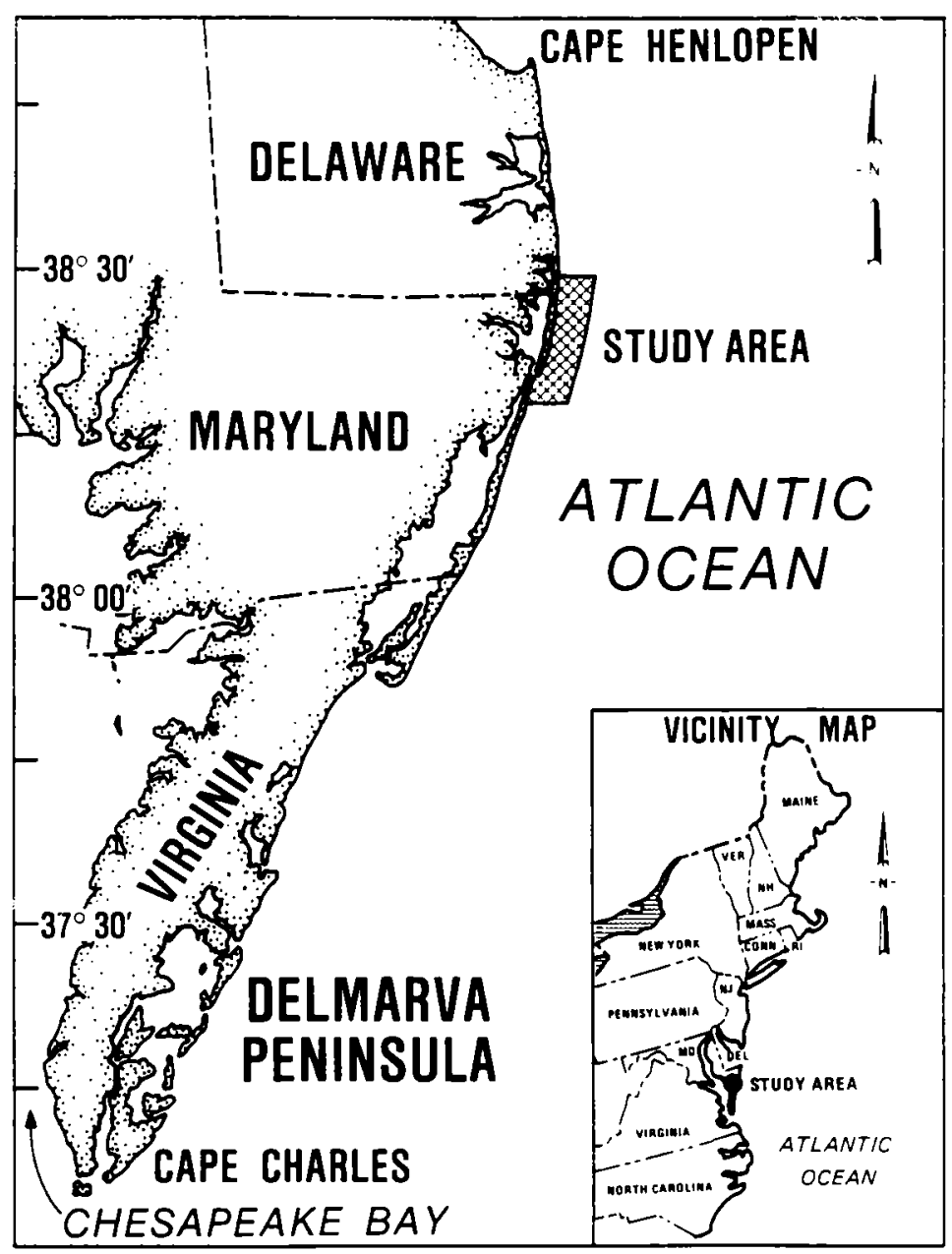

Figure 1. Location of the Ocean City field site along the Fenwick Island, Maryland, coastline

sea-level rise, sediment is carried into bays by inlets and overwash to form a foundation for development of a new barrier landward of the old barrier.

Historical data indicate several former inlets through Fenwick Island, which have since closed through natural processes (Truitt 1968). Physical evidence for barrier migration can be seen at Ocean City, where peat outcrops on the beach have been observed by the authors. Peat is formed in marshes on bay shorelines of barriers, and as a barrier rolls over itself, peat is eventually exposed on the ocean side. On developed barriers, rollover is incompatible with man's activities, requiring either alteration of natural processes or man's adaptation to nature.

6. Analysis of shoreline erosion rates by Knowles and Byrnes (in preparation) using historical maps and air photographs indicates a spatial and temporal variability in rate of erosion along Fenwick Island since at least 
1849. Average erosion rate for 133 years of historical shorelines measured was in excess of $3 \mathrm{ft} /$ year. The exception to this is just north of Ocean City Inlet, where accretion has occurred since jetty construction. Continued narrowing of the beach by long-term erosion has degraded the physical condition of the beach, increasing potential for damage during storms.

7. Beach erosion and property damage resulting during storms depend on a beach's physical condition and storm magnitude and duration. In the recent past, the most damaging storm at Ocean City has been the March 1962 Northeaster, which had a 6 -ft storm surge on top of spring high tides. Damage estimates for the Delmarva coast exceed $\$ 50$ million (Truitt 1968). Estimates by NAB* suggest that the 1962 storm exceeded the 100-year return interval. Since 1962, development has increased, and beach erosion has continued, resulting in potential for considerable damage should a storm of similar magnitude and duration occur and an increased likelihood of damage from less severe coastal storms. Numerous recent storms at Ocean City have caused severe beach erosion, but property damage has generally been light. Hurricane Gloria in 1985 destroyed the boardwalk and damaged some buildings, but its quick passage at low tide prevented large-scale property damage.

Environmental conditions

8. Information for Ocean City, as recorded in the "Atlantic Coast Hindcast, Shallow-Water, Significant Wave Information Report" (Jensen 1983), is presented in Figure 2. For the 20-year period 1956 to 1975, average significant wave height in $30 \mathrm{ft}$ of water was $1.94 \mathrm{ft}$, with maximum significant wave height recorded at $16.4 \mathrm{ft}$. The predominant wave period was between 7 and $8 \mathrm{sec}$. Approximately 32 percent of all waves along this segment of coast approach from the southeast quadrant, and 95 percent of this time these waves are less than $6.6 \mathrm{ft}$ high. Predominant southerly littoral drift is a result of waves from the east and northeast, which occur 25 and 23 percent of the time, respectively. Waves in excess of $6.6 \mathrm{ft}$ occur from the east and northeast 5 percent or more of the time. Wave Information Study (WIS) tables of hindcast significant wave height and largest significant wave height averaged for each month of the 1956 to 1975 period were used to calculate Figure 3. Monthly average values were averaged to determine mean significant

* Personal Communication, 1988, Edward Fulford, Andrews and Miller, Inc., Salisbury, MD. 


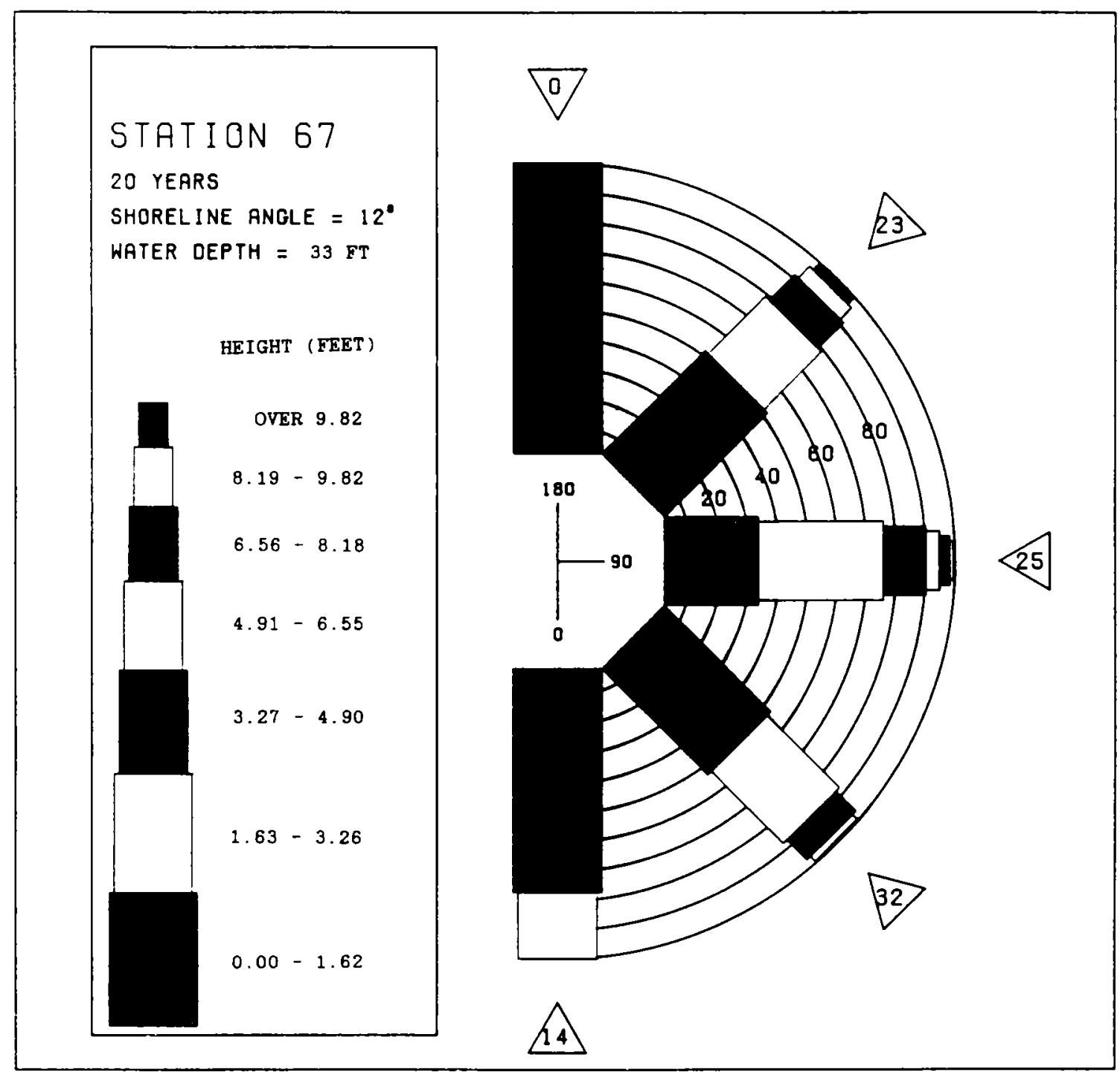

Figure 2. Wave Information Study (WIS) 20-year hindcast wave rose for station 67, Ocean City, MD

wave height and mean maximum significant wave height for each month of the year (e.g., average wave height for the month of July 1956 was averaged with the average wave height for July 1957, and July 1958, etc.). These curves are plotted in Figure 3 along with values for the largest average significant wave height per month between 1956 and 1975. Mean tidal range at Ocean City is $3.5 \mathrm{ft}$, with a spring tide range of $4.2 \mathrm{ft}$ and a mean tide level of $1.7 \mathrm{ft}$ above mean-low-water (MLW) datum.

9. The natural morphology of Fenwick Island spit is similar to other barrier spits; however, much of it has been altered by intense development. Bay shorelines have been extensively reshaped and filled for construction. Natural marshes have been severely displaced. Small craft canals have been 


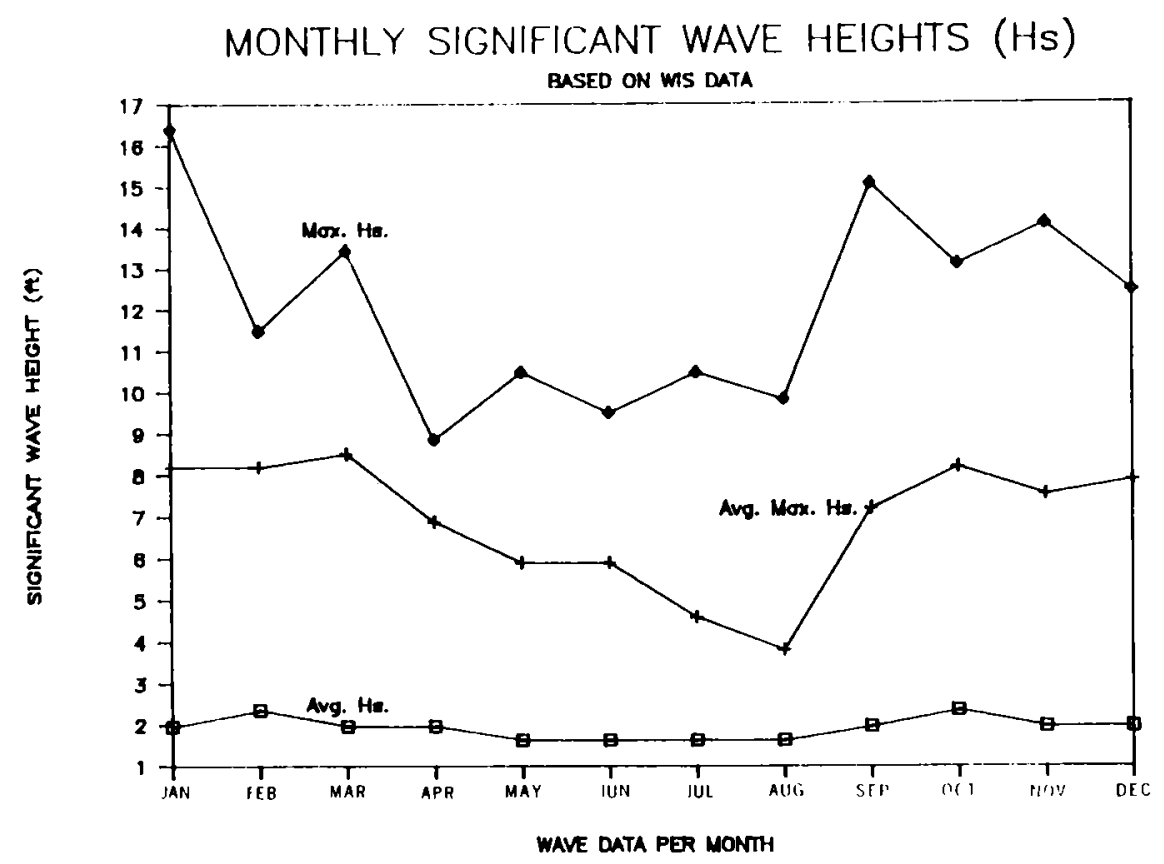

Figure 3. Hindcast monthly significant wave heights at Ocean City, MD, from 1956 to 1975

trenched into the barrier's bay side resulting in the narrowest point between ocean and bay being only about 1,000 ft wide; maximum spit width is approximately 6,000 ft. Elevation along most of the barrier is less than $10 \mathrm{ft}$ above MLW. Frontal dunes are generally absent, having been removed duringconstruction operations. Sediments composing the barrier spit, nearshore surface, and linear shoals are Holocene in age, overlying Pleistocene fluvial and shallow marine deposits (Field 1979).

10. Foreshore slope along Ocean City averages about 1:10 down to $-2 \mathrm{ft}$ below the 1929 National Geodetic Vertical Datum (NGVD), and from here to $-10 \mathrm{ft}$ (NGVD), slope becomes gentler, averaging 1:40. The $-30 \mathrm{ft}$ depth contour occurs within $3,000 \mathrm{ft}$ along most of the shoreline. Within 3 nautical miles (n.m.) of shore, depths range up to $-60 \mathrm{ft}$, although numerous shoals make nearshore bathymetry quite variable.

\section{Linear shoals}

11. Potential borrow sources considered for this project were shoals located offshore of Ocean City. Offshore shoals are present in numerous east coast locations. Scientific investigation of shoals has distinguished three major types: cape associated, such as Diamond Shoals located off Cape Hatteras; large estuary associated, such as those near the mouth of Delaware 
Bay; and linear, the variety found near Ocean City. Investigation of linear shoals as potential borrow sites was first conducted by the $\mathrm{CE}$ during the Inner Continental Shelf Sediment and Structure (ICONS) Program. Linear shoals along central Delmarva were examined under the ICONS Program by Field (1979) using maps, charts, vibracores, and geophysical data. Field discussed the value of these shoals as a sediment source for beach fill, but indicated additional work needed to be done before any particular shoal was selected for borrow.

12. Numerous investigations of shoals along coastal Delmarva have been reported in the scientific literature. Linear shoals are generally elongate features, with the long axis oriented in a north-northeast to south-southwest direction. They are typically 4.5 to $7.5 \mathrm{n} . \mathrm{m}$. long, 0.75 to $1.25 \mathrm{n} . \mathrm{m}$. wide, with side slopes of 0.75 to 2.0 deg. Relief above local terrain is 20 to $50 \mathrm{ft}$. Sedimentological investigations have shown shoals are composed of Holocene age, medium to very fine sands underlain by silts and clays. Linear shoal origin has not been specifically determined. Several authors support the idea that linear shoals are submerged barrier islands and coastal plain landforms. Others support wave-induced currents during storms as a mechanism for origin. A more plausible explanation is advanced by Swift, Duane, McKinney (1974) and Field (1979); i.e., once an irregularity develops in the nearshore zone, southerly littoral drift and barrier migration westward result in north-northeast to south-southwest elongation of the feature. Eventually a shoal detaches from the shoreface and becomes isolated on the shelf as the barrier migrates away. Preliminary investigation of the present ebb delta and several linear shoals indicates their initial origin as a shoreline irregularity may be related to inlet ebb-tidal delta deposition. This implies that each shoal corresponds to the dynamic position of a former inlet as the barrier migrated landward.

13. A total of nine shoals were investigated as potential borrow sources for this project (Figure 4). Inland sites were not considered feasible. Shoals 1, 2, and 3 were originally designated as primary borrow sites based on data reported by Field (1979). After initial field investigations, shoals 4 and 5 were added to the list of primary borrow sites. All shoals investigated were between 0.5 and $3 \mathrm{n} . \mathrm{m}$. offshore, within Maryland territorial waters. 


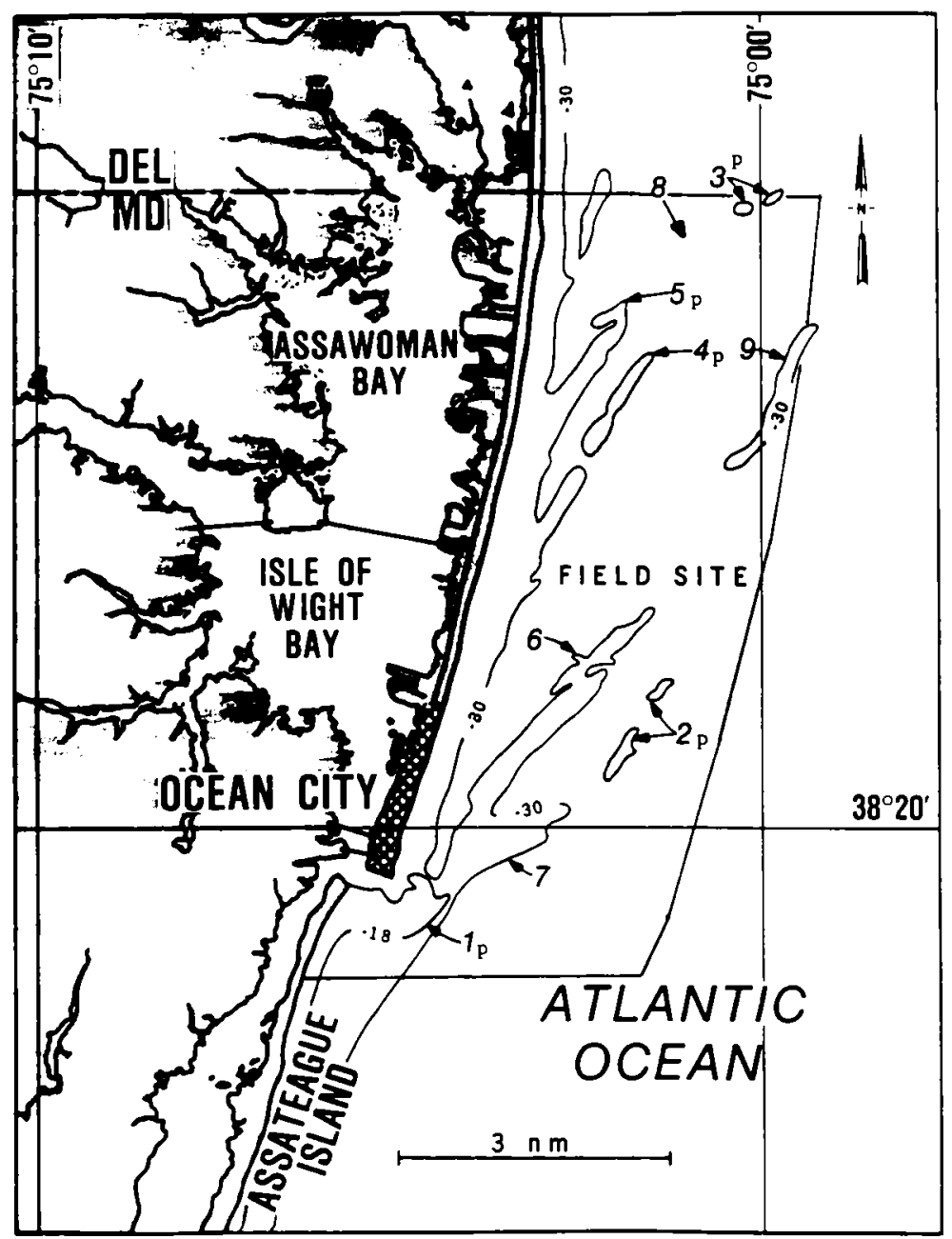

Figure 4. Location of shoals/potential borrow sites at Ocean City, MD; $p=$ those designated later as primary sites

\section{Beach Nourishment Guidelines}

14. Beach nourishment is one of many shore erosion control methods used to provide recreational beaches and storm protection. The main advantages over other engineering methods is that it provides a wide beach which is aesthetically pleasing and not hazardous to users, wave energy is dissipated naturally across the beach, there are generally few related problems downdrift (an exception can be inlet filling), and cost can be low compared with alternative erosion control measures. Disadvantages are that construction guidelines are not well developed and periodic maintenance is generally required to provide project design specifications. Problems that arise with beach 
nourishment are often due to lack of technical information, particularly sediment characteristics, for the project. Walton (1977) noted this problem in investigating recent nourishment projects in Florida. It was also noted by Walton and by Stauble (1985) that few projects contained any postfill evaluation of performance or impact that could be used to modify construction guidelines.

15. The objective in beach nourishment is to obtain sediment from some borrow source that, once placed on the beach, will compensate for recent erosion trends. Coarser sediment placed on the beach will better withstand erosion. However, coarse sediment such as gravel is not as aesthetically pleasing as sand and is usually not preferred for recreational beaches. Coarse sand and gravel are not as common as fine sands and silts and therefore are difficult to locate and often more expensive to use. Fine sand is generally not resistant to erosive processes. Therefore, the goal is to find a borrow source which is as coarse or slightly coarser than the native beach, or a source which has a wide variety of grain sizes such that after sorting by waves the resultant beach is similar or slightly coarser than the original beach.

16. Field data collection guidelines for a beach nourishment project are presented in the Shore Protection Manual (SPM) (1984). Information required for a beach nourishment project includes longshore transport directions, which can be determined from natural coastal morphology, impoundments of sediments at artificial littoral barriers, or directional wave information. Grain size characteristics of the native beach in the zone of active littoral transport are required. Similarly, borrow site samples are required for calculation of sediment overfill ratios. Detailed borrow site evaluation guidelines are not available. Enough samples are required to develop a composite sample that is an accurate representation of the entire borrow site. A twophase sampling plan is recommended, the first phase to locate potential sources and a second phase to detail sediment characteristics in those sites. Accurate profiles of the beach out to closure depth are necessary to determine the shape of the native beach and calculate volumes necessary to develop the design beach. Design beach criteria (such as berm elevation and width, slope of fill material, how transition to adjacent beaches will be handled, and location of feeder beaches if planned) are also necessary for effective planning. 
17. Typical procedure for specification of material for use in beach nourishment projects is based upon grain size characteristics of native beach and borrow materials. It is assumed grain size found on a project beach reflects waves and currents that operate within the 1ittoral zone (Hobson 1977). To characterize a native beach, numerous sediment samples are col: lected across the beach along several profiles from dune base to closure depth. Field collection of samples should take place two different times of the year (preferably summer and winter) for a minimum of 1 year. Textural properties of all samples are combined into one sample to obtain a "composite" native beach sample. Composite grain size is determined by mathematically averaging individual size fractions of many samples to form one composite sample. Statistical analysis is performed on the composite sample to determine overall mean and standard deviation of the beach.

18. Coring is generally the method used to identify textural properties of offshore borrow site sediment. Cores are located to provide the best representation of borrow areas. Sediment samples from individual cores are mathematically combined with samples from other cores into one "composite" sample to determine the composite borrow site grain size.

19. Several models are available to determine amounts of stable beach material required for a project (Krumbein and James 1965, Dean 1974, James 1975). The most commonly used model, Adjusted Shore Protection Model (James 1975), estimates how much borrow material is initially required to produce fill material with characteristics similar to the native beach sediment. It assumes resorting of fill as fine material will be winnowed out. As a result, the ratio of native sediment required to complete the project to borrow sediment needed for completion will be greater than one in order to replace fines lost in sorting. The SPM (1984) notes James' overfill ratio is not fully tested in the field and should therefore be used only as a general indication of beach-fill behavior. Furthermore, this calculation assumes a log-normal distribution of sediment texture, which is often not the case in borrow sites where the possibility of bimodal, layered, sediments are high. A second commonly used model, renourishment model (James 1975), estimates long-term behavior of a particular borrow source based upon native beach retreat rates. This calculation gives a rough indication of residence time of fill sediment on the beach and thus is a measure of how often renourishment will be required if a particular borrow site is used. Fill material removed from the subaerial 
beach is moved offshore to fill the profile out to closure. Some of this sediment will be lost to greater depths and to longshore currents. Hobson (1977) suggested addition of a safety factor to the Adjusted Shore Protection Model to account for the proportion of unstable borrow material below 4 phi. Stauble, Hansen, and Blake (1984) found that of the several models available, the Adjusted Shore Protection Model gave the best calculation of actual fill behavior provided a safety factor was used to account for proportions of unstable material finer than 3 phi. 


\section{Native Beach}

\section{Sampling plan}

20. The MOA between DNR and CERC specified collection of grab sediment samples along each of 36 profile lines (Figure 5) at the following locations: midberm, mean-high-water (MHW); midforeshore, MLW, $-2,-6,-12,-18,-24,-30$, and $-36 \mathrm{ft}$ (Figure 6). A total of $396 \mathrm{grab}$ samples were to be obtained over the entire beach and nearshore area. Sampling of the native subaerial and subaqueous beach was conducted coincident with profile surveys. Profiles were obtained using a seasled with a $40-\mathrm{ft}$ mast, which was towed over the nearshore along each profile. A shore-based Zeiss Total Station recorded sled position

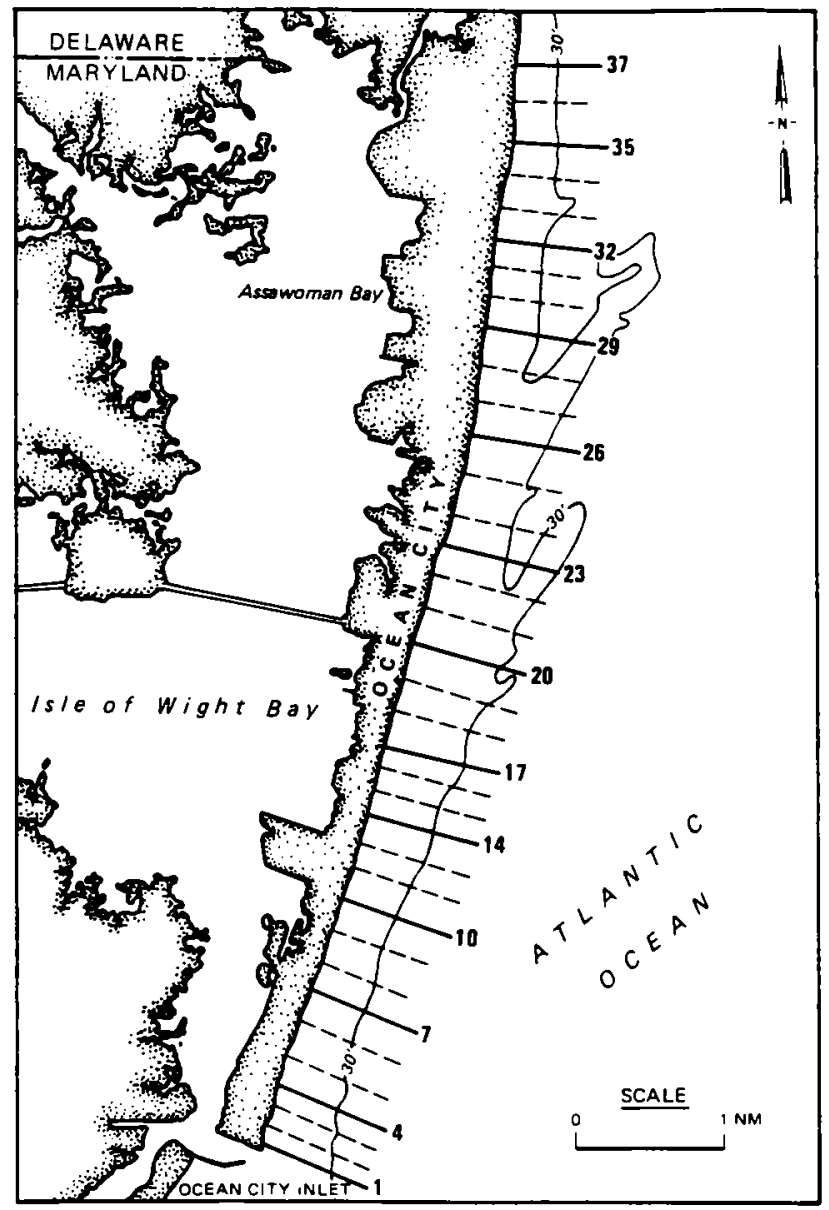

Figure 5. Approximate location of beach survey profile lines 


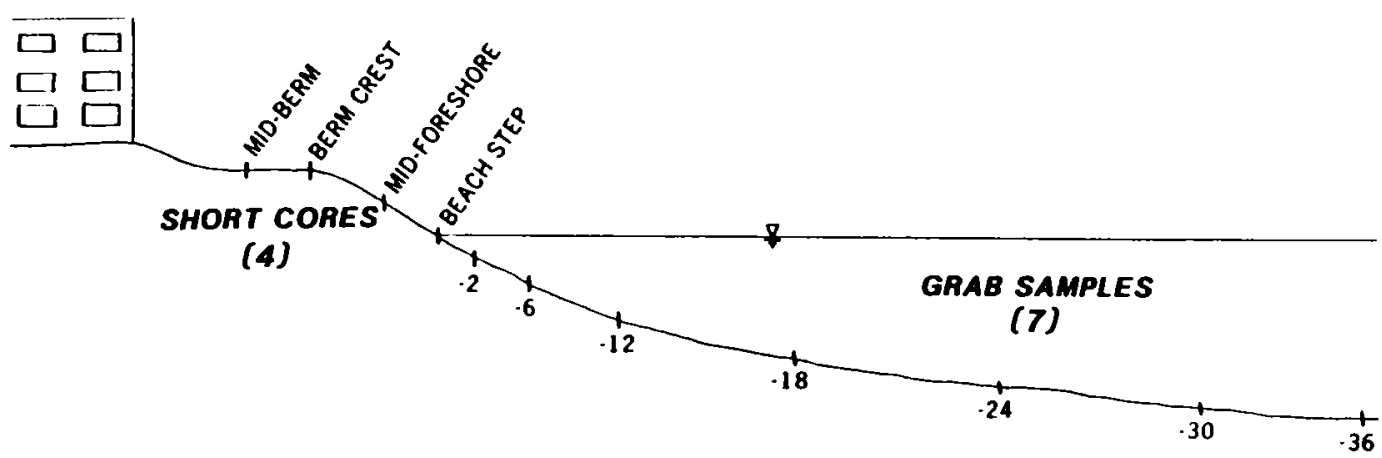

Figure 6. Location of sediment samples along the profile

and elevation at selected points along each profile by shooting optical prisms mounted on top of the sled mast.

21. Several modifications to the original sampling plan were required based on field conditions and proposed time schedules for the study. Positions of MHW and MLW are located in the field through use of precise surveying techniques based on a history of tidal information and beach profiles from a known datum. Since no benchmark datum was established at Ocean City for reference at the time of survey, beach samples were collected at berm crest and beach-step positions instead of MHW and MLW, respectively. The berm crest, generally recognizable in the field, defines inland limits of recent maximum wave swash, which is a rough approximation of MHW, although displaced slightly landward. Berm-crest position at Ocean City is approximately midway between midberm and midforeshore sampling points. Likewise, the beach step was selected instead of MLW because of easy field recognition and suitable position from the midforeshore sample. The step, formed at the point of breaking waves, is seaward of MLW and usually represents the zone of maximum grain size. Samples collected at this location provide coarse fraction definition.

22. Remaining samples were collected as close to specified depths as possible. However, no datum was available at the time of sampling to determine exact survey instrument height on each line, nor exact tide stage. Therefore, at the time of sampling only approximate sample depth was known. In addition, on many lines depth never exceeded - $30 \mathrm{ft}$ before limits of the shore-based survey instrument (approximately 7,000 ft) were exceeded. As a 
result, samples farther from shore were often collected after a reasonable distance between samples was exceeded, even if requisite depth was not reached. In all cases, relative location of samples was recorded, and exact y and $z$ positions for each sample on the survey line ( $x$ ) were calculated later once a datum was established.

23. Samples were collected coincident with beach profile surveys, starting at the southernmost profile 1 and working progressively north to profile 37 (there is no profile 12). Subaqueous grab samples were collected using an Eckman clamshell sampler from the deck of a LARC V amphibious vehicle. At the correct position, the vessel would back up alongside the survey sled and collect a sample. Relative sample location on each profile line was noted during the survey.

Short cores

24. The SPM (1984) recommends surface grab samples be collected in winter and summer to obtain maximum range of grain sizes on the native beach for nourishment projects. Knowledge of winter beach characteristics is particularly useful since coarse grains, which are most stable during storm events, are usually present then on the beach surface as lag deposits. However, time factors involved in the overall project prevented collection of beach samples at several intervals. Instead, the four subaerial samples on each survey line were collected as short cores ( 1 to $6 \mathrm{ft}$ ) as an alternative plan for collecting temporal data. Profile information collected prior to field work indicated the subaerial envelope of sediment change between winter and summer beach at Ocean City was approximately $3 \mathrm{ft} . *$ Short cores were used to penetrate through the active beach to obtain samples from each distinct sediment horizon. Each horizon represents erosion (lag deposits) or deposition under different environmental conditions. By penetrating the typical active beach thickness, samples can theoretically be obtained from a large variety of depositional events that occurred throughout the year. Each core represents sediment within the active layer. In contrast, surficial sampling can only collect data representative of recent depositional events, and hence temporal surficial sampling is needed to obtain enough samples to be representative of the beach in all its conditions.

* Personal Communication, 1986, Edward Fulford, Andrews and Miller, Inc., Salisbury, MD. 
25. Figure 7 compares mean grain sizes of samples collected from cores versus mean grain sizes of only surface sediment in each core. It is evident from the data distribution that a composite mean derived from surface sediments would have a much finer grain size than a composite mean from samples collected throughout cores. Surficial sampling several times throughout a year would presumably produce a distribution of mean grain sizes similar to that obtained by coring. An advantage to coring then is that samples representative of the entire active beach envelope can be obtained in one field operation. Field time involved in collecting short cores is greater than collecting one set of surface samples, but less than seasonal surface sampling. This technique was not feasible in the nearshore; however, evidence suggests (SPM 1984) temporal grain size changes within this zone are generally not as large as on the beach face; therefore, it was assumed one surficial sampling was adequate to represent temporal grain size distribution.

MEAN GRAIN SIZE VS DISTANCE FROM INLET

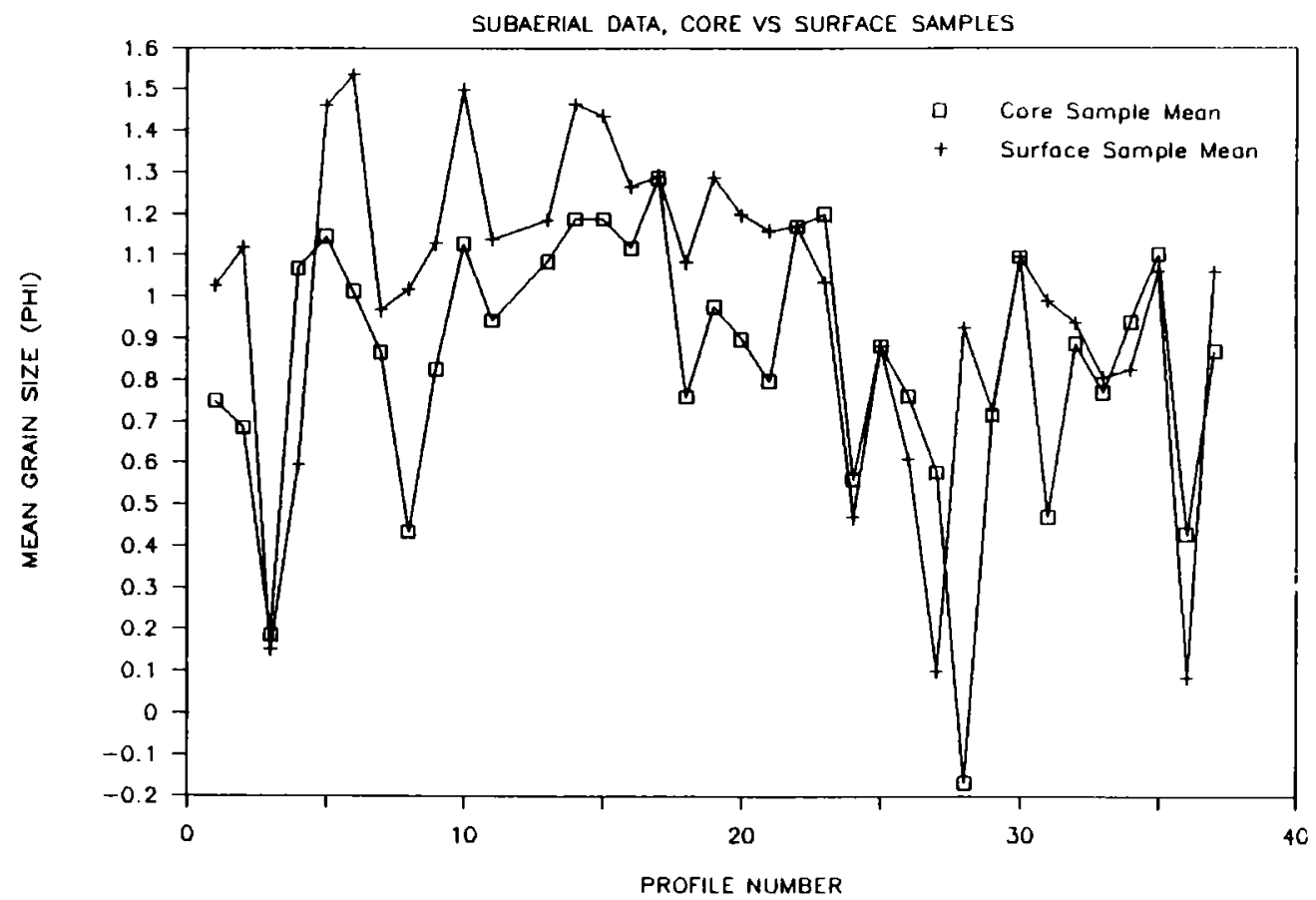

Figure 7. Comparison of mean grain size along beach transects obtained from surface and core samples

26. Four beach cores along each profile were collected by manually driving 3-1/2-in.-diam polyvinyl chloride pipe into the beach at proper locations. Cores were then sealed and extracted manually. Each pipe was capped, labeled, and returned to the laboratory where each core was split 
longitudinally and visually examined. Sediment samples were extracted from each visually distinct horizon. Vertical variation in sediment texture was generally identified based on alternating coarse sediment lag layers with uniform medium sand.

27. Several questions remain unanswered in using short cores for collection of sedimentological data. One question is what depth to penetrate to. Since penetrating the active beach is ideal, how should active beach be defined? In a normal year, the active beach may change $3 \mathrm{ft}$ vertically between erosional and depositional events. However, during a stormy year, this range may be dramatically increased since erosion and deposition related to a severe storm may be great. If a beach fill is designed to withstand a 10- or 20-year storm, then sediment samples representing the active layer for a year containing a 10 - or 20-year storm should be collected. Ideally, cores should be collected during summer months when the active layer is at its maximum thickness and wave conditions are at a minimum.

Active sediment layer determination

28. Determination of the thickness of the active layer can be accomplished accurately through repetitive profiling over a period of years or approximated by calculation. DeWall and Christenson (1984) examined profile changes from a variety of US locations and found the following empirical relationship:

$$
\mathrm{y}_{\max }=1.15 \mathrm{H}_{e}-4.1
$$

where $y_{\max }$ is the maximum scour of the profile and $H_{\theta}$ is the extreme wave height as discussed by Hallermeier (1981). For typical use:

$$
\mathrm{H}_{\mathrm{e}}=\mathrm{H}_{\mathrm{s}}+5.6 \mathrm{O}_{\mathrm{Hs}}
$$

where $H_{s}$ is average significant wave height for a year and $o_{H s}$ is standard deviation of average significant wave height.

29. Using the WIS (Jensen 1983) 20-year hindcast data for Ocean City in Equation 2,

$$
H_{\theta}=1.94+5.6(1.64)=11.12 \mathrm{ft}
$$


Substituting this into Equation 1,

$$
y_{\max }=1.15(11.12)-4.1=8.69 \mathrm{ft}
$$

This is the average maximum scour at Ocean City for a 20-year (1956-1975) period. A similar calculation to determine maximum scour, by substituting data from the most extreme hindcast year during the 20-year interval, yields $y_{\max }=9.39 \mathrm{ft}$. This implies that for cores to penetrate the average active layer, they need to be at least $8.7 \mathrm{ft}$ long, and if fill design is for 20 years, they should be at least $9.4 \mathrm{ft}$ long.

30. The active layer thicknesses calculated above represent the maximum scour along the profile. DeWall and Christenson (1984) point out that maximum profile variability generally occurs in the zone between foreshore and outer bar. Howd and Birkemeier (1987) show the envelope of change along one profile line in Duck, NC, for a 4-year period (Figure 8). Maximum vertical change

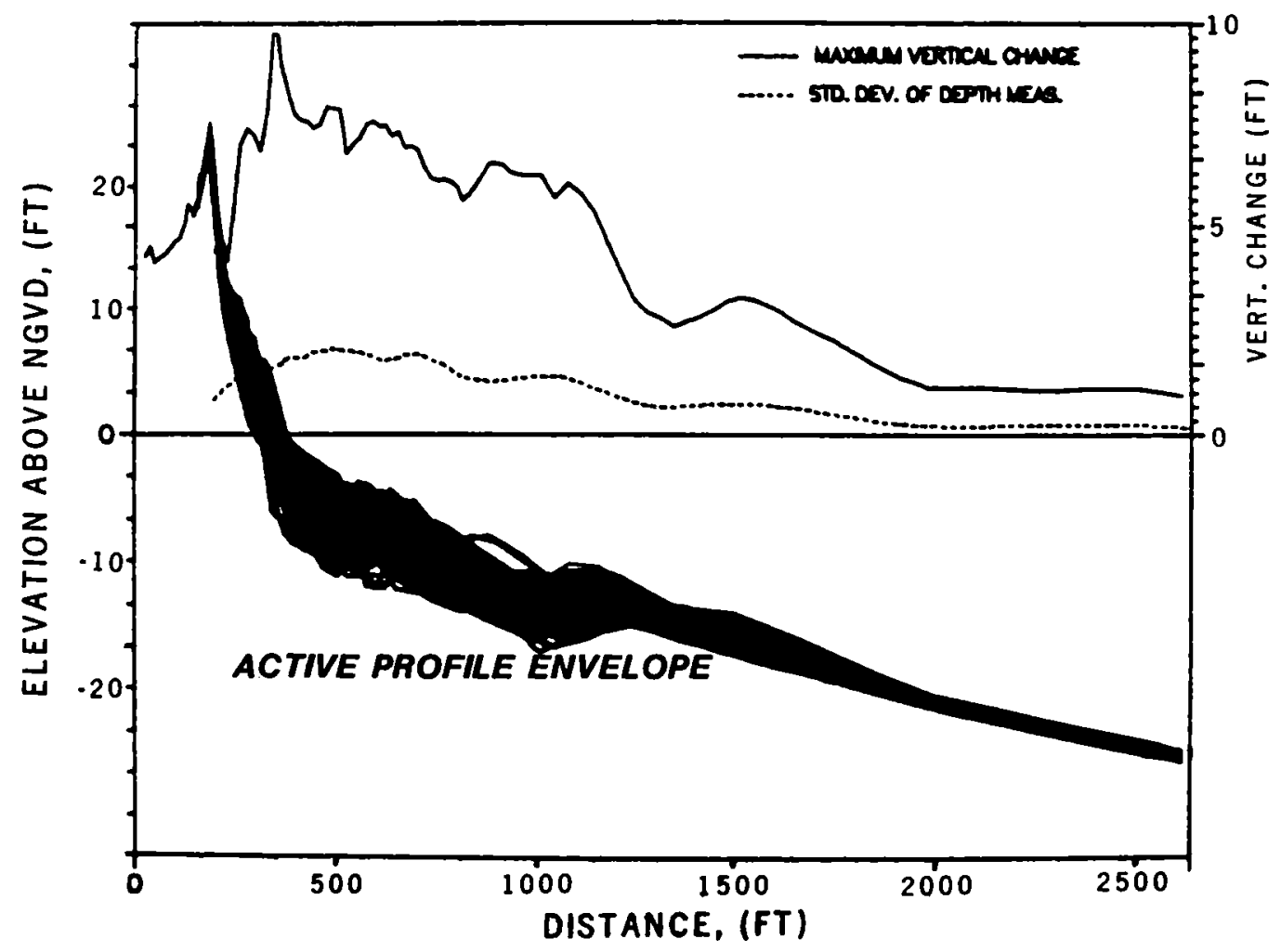

PROFIE LINE 188, 127 SURVEYS FROM JAN TO DEC 84

Figure 8. Example of seasonal envelope developed from profile change data at Duck, NC (Howd and Birkemeier 1987) 
occurs in the vicinity of the step and decreases rapidly landward. Seaward, vertical change decreases slowly past the outer bar to closure. Unfortunately, coring between the step and outer bar is quite difficult because of breaking waves and longshore currents. At the present, scientific literature indicates temporal sediment variability in this zone is smal1 (SPM 1984), which if correct is fortunate because it would mean cores are not required. Grab samples were used seaward of the step at Ocean City. However, temporal sediment variability in this zone needs to be further investigated to substantiate these ideas.

31. A second question is how to sample sediment within cores. The easiest and perhaps best solution is to take a continuous channel sample along the core, which would represent all core sediment in its proper proportion and be an average of the active envelope at a location. Each channel sample would be used to develop the composite beach sample. An alternative, which was used in this study, is to individually sample each distinct layer in a core and treat each as though it were a separate surficial sample collected at a different time. The result was that 273 samples were removed from the subaerial beach cores. For comparison, one surficial sampling of the same grid would have collected 119 sediment samples; 238 would have been collected if two surficial samplings had been done at different times.

\section{Efficient sample design}

32. A sampling question that arose with data from Ocean City is how far to sample offshore. The MOA specified sampling out to $-36 \mathrm{ft}$ NGVD. However, Hallermeier (1981), SPM (1984), Birkemeier (1985), and Howd and Birkemeier (1987) demonstrate little sediment motion occurs beyond closure depth, the point of wave shoaling. Samples seaward of closure are not useful for fill design on the active portion of the beach and, in fact, may be harmful by influencing the composite mean to the fine direction. Sampling only to closure depth at Ocean City would have reduced nearshore collection efforts by 72 samples.

33. Calculating closure depth. A problem exists, however, in defining closure depth. Figure 9 shows the calculated annual closure depth at Ocean City using techniques outlined in the SPM (1984) and by Birkemeier (1985) and 20 years of hindcast wave data from the Atlantic Coast Wave Information Study (Jensen 1983). Figure 9 shows no matter which technique is used to calculate closure depth, its annual position is quite variable. In fact, closure depth 


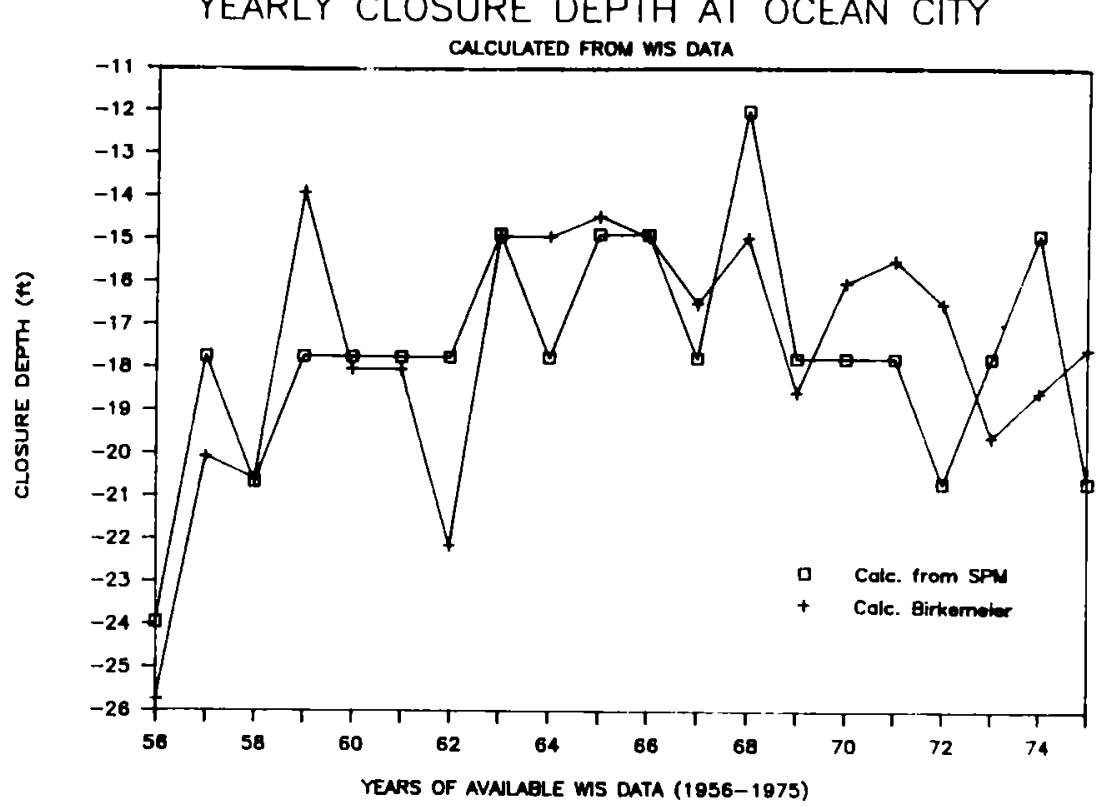

Figure 9. Yearly variation of calculated closure depth at Ocean City

varies daily. On days of calm conditions, closure depth is significantly inshore of positions on Figure 9. During storms, it would be significantly offshore. To sedimentologically characterize the active native beach, the seaward limit of sediment collection should extend to a sampling closure depth which is justifiable in light of intended project performance. Closure depth is quite variable, and the common practice of selecting it based on a short time interval of data could be misleading for both sampling and design purposes. At a minimum, sampling closure depth should be consistent with wave conditions anticipated during the span of a typical renourishment interval, keeping in mind that during a given renourishment period, the project may be visited by events with return periods significantly greater than the renourishment interval.

34. Determining number of samples. Subsequent to completion of field sampling, the sampling plan for grain size data was evaluated for sampling efficiency (Anders, Underwood, Kimball 1987). Original plans called for 11 samples per profile line (Figure 6) times 36 lines for a one time total of 396 samples. Comparison of sediment data from all samples suggests reorganization of sampling strategy would have allowed an equally valid composite sample to be calculated with collection of only 102 samples. The difference resulted from small spatial variability of sediment grain size along the subaerial beach and within the nearshore zone. Using data from 396 samples as 
test samples, mean grain size and standard deviation were calculated for various beach subenvironments. This information was used in the following relationship:

$$
\mathrm{n}=\left[\frac{\mathrm{s}(\mathrm{t})}{\mathrm{d}}\right]^{2}
$$

This equation, presented by Krumbein and Greybill (1965), predicts the required number of samples ( $n$ ) to obtain a mean that is within $d$ units of the true population mean, given standard deviation of test samples (s) and student's $t$ value, which is taken from a table for $t$ test of significance between two sample means. The value of $t$ depends on degrees of freedom ( $\mathrm{df}=$ number of samples -1 ) and $a / 2$ (which is related to the probability of having $t$ this large or larger in size by chance).

35. The number of samples required to accurately characterize the beach at Ocean City to within 0.25 phi of the true mean grain size 95, 97.5, and 99 percent of the time are presented in Table 1.

Table 1

Number of Samples Required to Determine Mean Grain Size of Beach to Within 0.25 phi Accuracy at Given Levels of Confidence

\begin{tabular}{|c|c|c|c|c|}
\hline \multirow{2}{*}{$\begin{array}{l}\text { Subenvironments } \\
\text { of the Beach }\end{array}$} & \multicolumn{3}{|c|}{$\begin{array}{l}\text { Number of Samples Required } \\
\text { at Various Confidence Levels, } 8\end{array}$} & \multirow{2}{*}{$\begin{array}{l}\text { Number } \\
\text { Collected }\end{array}$} \\
\hline & $\underline{95}$ & $\underline{97.5}$ & $\underline{99}$ & \\
\hline Midberm & 2 & 3 & 4 & 36 \\
\hline Berm crest & 2 & 3 & 4 & 36 \\
\hline Midforeshore & 5 & 8 & 11 & 36 \\
\hline Beach step & 43 & 62 & 89 & 36 \\
\hline$-2 \mathrm{ft}$ & 24 & 35 & 51 & 36 \\
\hline$-6 \mathrm{ft}$ & 8 & 12 & 17 & 36 \\
\hline-8 to $-36 \mathrm{ft}$ & 18 & 26 & 37 & 180 \\
\hline
\end{tabular}

36. Redesigning sampling schemes to take advantage of small alongshore variability of sediment landward of the offshore bar would greatly reduce the required number of samples while keeping a high level of accuracy and confidence in results. Using a smaller number of samples to calculate composites 
would require a change in calculation procedures. Two basic routes are possible. One way would be to assume each subenvironment (e.g., berm, foreshore, bar, etc.) was equally important and calculate a composite for each subenvironment. Composites for each subenvironment would be used to calculate an overall composite for the entire beach. An alternative is to use composites for each subenvironment in a scheme that weights its relative importance to beach fill. For example, subenvironments, where fill would be placed and where it is intended to remain, may be weighed more heavily. Most sediment movement on the beach occurs between the berm and offshore bar (Figure 8). It is logical to weigh equally spaced composite samples for each subenvironment equally through this zone, and outside the zone both landward and seaward have a lower weighing. Defining more subenvironments in the active zone would be one way to accomplish this. An improved method, currently being developed in the Beach Nourishment work unit at CERC, is to weight the samples based on the portion of the design volume within each subenvironment.

37. To illustrate an efficient sampling plan, let us assume we are planning to sample a beach for beach nourishment. We conclude samples must be collected between the dune base and closure depth. From profile data, we determine the very active beach zone, which begins about $20 \mathrm{ft}$ seaward of the dune out to $-6 \mathrm{ft}$ in elevation at the outer bar seaward slope. This highly active zone should be emphasized in sampling since it is here where beach fill is more apt to be redistributed and therefore sediment needs to be most stable. Within this zone, we decide that we will define an alongshore position (subenvironment) every $10 \mathrm{ft}$ from the landward boundary. Within each of these subenvironments, we collect samples based on alongshore variation of grain size. Using Table 1, those subenvirons near the berm might require only 2 samples each over 8 miles of beach to derive a composite whose mean is within 0.25 phi of the true mean 95 percent of the time. Those subenvirons on the foreshore would require 5 samples (spaced along the beach), the step region would require 43 samples, etc. Data indicate coarser beaches will require more samples than finer beaches. A test sampling could be taken on any beach and analyzed to determine exact numbers of samples that must be collected in each subenviron. A composite sample would be calculated for each subenvironment. Outside the very active zone, between the dune and berm and the outer bar and closure depth, subenvironments are defined every $20 \mathrm{ft}$, and appropriate numbers of alongshore samples are collected. Composites for each 
subenvironment are calculated. Composite samples for all subenvironments are used equally to calculate the entire beach composite, but since there were more subenvironments defined in the highly active portion of beach, it influenced overall composite mean and deviation more than areas outside of it.

\section{Borrow Sites}

38. Complete evaluation of borrow sites required extensive field data collection. The DNR and NAB contracted for detailed hydrographic surveys over each primary borrow site. Environmental assessments were completed over each site and surrounding areas to identify potential dredging impacts to flora and fauna. Archeological surveys were conducted to ensure dredging would not damage any historically valuable objects. Numerical wave refraction studies were conducted to examine potential erosional effects of borrow site mining on adjacent shorelines. The CERC was contracted to collect geophysical records and sediment cores for evaluation of sediment compatibility with native beach material. The hydrographic surveys, environmental assessments, and archeological surveys were completed prior to sedimentological investigations. However, numerical wave refraction studies were completed concurrently with CERC's work (Grosskopf and Resio 1987). In retrospect, there could have been a cost savings if modeling work had been completed first. Shoal/borrow site 1, the ebb-tidal delta of Ocean City Inlet, was found by numerical modeling to be unsuitable for mining. Removal of even a small amount of sand from this shoal would result in potential for serious shoreline erosion. Consequently, this shoal was removed from the list of potential borrow sites. Had this been known prior to starting sedimentological field work, it would have saved collection of nine cores, 15 miles of geophysical data, and numerous hours of laboratory analysis.

\section{Geophysical data collection}

39. Geophysical data were collected on potential borrow sites during three cruises in 1986. Instruments used were a stern-towed Klien side-scan sonar fish operating at $100 \mathrm{kHz}$ at a range of $325 \mathrm{ft}$ and an ORE subbottom profiler mounted on a pole over the side of the vessel and operated at $3.5 \mathrm{kHz}$. All geophysical information was recorded on dry paper records and displayed in real time. 
40. The primary purpose behind collecting geophysical data was to examine thickness and lateral continuity of sedimentary units found in borrow sites. High quality records can be used to distinguish sediment texture, but CERC's records were generally not detailed enough. In addition, geophysical data can show any unsuspected features in the borrow source. A buried relict channel with good likelihood of usable sand was found beneath borrow site 4 . To help clarify the nature of borrow sediments required geophysical records that were of high resolution, but deep penetration was not critical. Two instruments were initially selected for use, the Geopulse Uniboom and the ORE subbottom profiler, because they emit relatively short wavelength acoustic energy that has limited penetration but high resolution. Both instruments were designed for operation in the relatively shallow-water conditions encountered. After the first cruise, the Geopulse instrument did not return high quality records in this area, and it was eliminated. This instrument has proven useful for obtaining shallow penetration, high resolution records in other areas. The subbottom profiler had marginal success, which improved on subsequent cruises. A 15 -cfm water gun was also tested, but its long wavelength did not provide the required resolution. The very short acoustic wavelength of side-scan sonar was intended to provide surficial information on borrow sites.

41. Both subbottom profiler and side-scan instruments operate by generating an acoustic wave front (a sonic pulse) and then recording wave reflection. The ORE subbottom profiler sends a low frequency acoustic wave front out in short bursts downward. This signal penetrates below the seabed, and reflections are returned from deeper horizons. Reflected signals received by the instrument and displayed on paper record show both sea bottom and several deeper reflectors (sediment horizons). These deeper reflectors are produced when sediment changes in some profound manner, such as where a sand layer meets a clay layer. Reflection at this interface is due to a difference in rates at which sound is propagated through both mediums. It is important to remember that geophysical records cannot be read directly in depth below sea level. Recorded data represent wave travel time: the time it takes the acoustic wave to travel from instrument to reflective horizon and return. Sonic velocities through each horizon must be used to convert travel times to distances. These velocities are never precisely known over an area as they 
typically change both vertically and laterally through sediment. Some minor imprecision is thus inherent in all related measurements.

42. Extremely short wavelengths used by side-scan sonar result in acoustic energy not penetrating the seabed but instead being reflected. Sidescan sonar emits a sonic pulse at an angle to the left and right of the vessel. A record of bottom features in a swath on both sides of the vessel results, based on changes in reflectance characteristics of bottom sediments and changes in bottom relief. Typical of side-scan records over Ocean City borrow sites was evidence of sand waves on shoal flanks, indicating sediment transport, and patches of coarse-grained materials, perhaps shell hash at the base of shoals. In this survey, a swath $325 \mathrm{ft}$ wide on each side of the boat was covered. The side-scan instrument was provided at no cost to this study. Limited use of side-scan data for sedimentological evaluation of borrow sites would preclude use of this instrument if a cost were attached. Side-scan and magnetometer surveys can prove useful for locating potential hazards to dredging.

43. Operating geophysical instruments were towed in a grid pattern over the area to be surveyed. Grid geometry over primary borrow sites was established so that grid lines, lying at right angles to the shoal axis, were spaced at $575-\mathrm{ft}$ intervals (Figure 10). Tie lines were spaced at larger and more irregular intervals, approximately parallel to the shoal axis. Spacing of lines at 575-ft intervals allowed for overlap of side-scan sonar data. Additional lines were used to investigate borrow sites of secondary interest. Geophysical data collected over each shoal are presented in Table 2.

44. Navigational control for each cruise was established by using MiniRanger and Loran $C$ systems alone or in combination. Navigational information was fixed at 2 -min intervals on the geophysical records. In retrospect, some confusion would have been avoided using only one locational system. The MiniRanger system is more precise, but requires setup in the field. The Loran $C$ system is easier to use and is commonly found on vessels. Its accuracy is probably adequate for geophysical surveys of this type where horizontal sediment changes are broadly spaced.

45. No guidance exists in the SPM (1984) on use of geophysical instruments for exploring or characterizing borrow sites. Geophysical records are an excellent supplement to core data, providing information on thickness, 


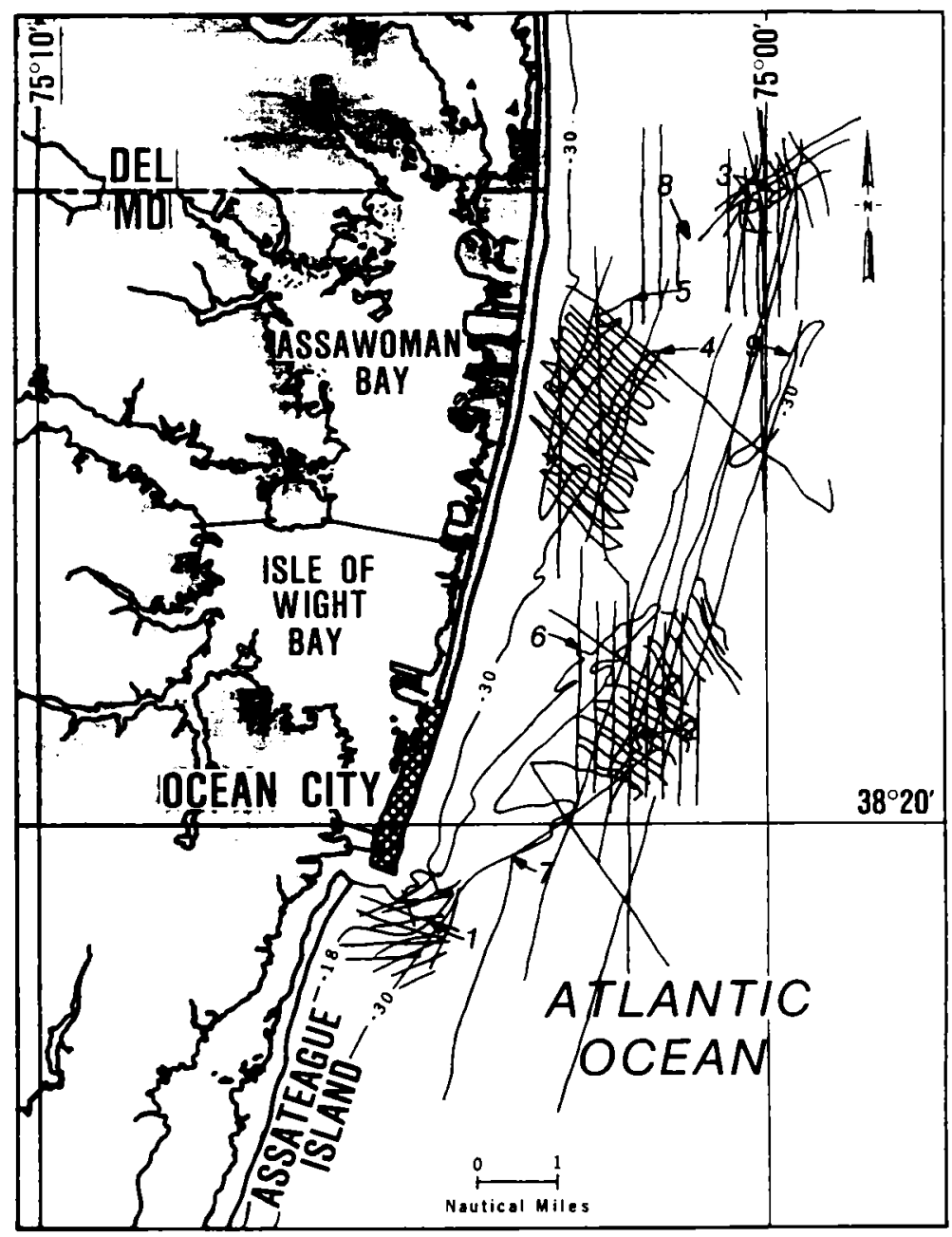

Figure 10. Approximate location of geophysical track lines

lateral continuity, cross-sectional shape, and angle of inclination of sedimentary units. Experience from this project suggests a single high resolution unit is sufficient. The number of track miles to collect is dependent on whether the survey area is a defined borrow site versus an exploratory site and on the size of the area to be surveyed. The quality of obtainable records can also influence how many to collect. Ideally, track lines for geophysical surveys should be coincident with grid layout for core collection.

Sediment data collection

46. A total of 57 cores, each $20 \mathrm{ft}$ long, were collected over nine potential borrow sites (Figure 11). The SPM (1984) suggests a two-phase coring program, taking exploratory cores first, followed by detailed 
Table 2

Borrow Site Geophysical Data Collected at Ocean City

\begin{tabular}{ccc}
\hline $\begin{array}{c}\text { Shoal/Borrow } \\
\text { Site Number }\end{array}$ & $\begin{array}{c}\text { Miles of } \\
\text { Subbottom Profiles }\end{array}$ & $\begin{array}{c}\text { Miles of } \\
\text { Side-Scan Sonar Records }\end{array}$ \\
\cline { 2 - 3 } 1 & 14.7 & 1.6 \\
3 & 49.9 & 32.5 \\
$4 / 5$ & 35.5 & 25.2 \\
6 & 42.8 & 41.1 \\
7 & 9.6 & 7.7 \\
8 & 7.8 & 7.8 \\
9 & 6.3 & 0.0 \\
Connecting lines & 7.6 & 7.6 \\
Totals & 25.1 & 25.1 \\
& 199.5 & 148.4 \\
\hline
\end{tabular}

coring on specific sites. This procedure is an excellent idea; however, both cost and time factors prevented this at Ocean City. Fortunately, Field (1979) had sampled a few shoals to indicate sand was present. Of nine shoals investigated, three were designated as primary borrow sites for coring based on data from Field. A fourth primary site was added based on geophysical information. These four sites received the majority of cores. The remaining five shoals, which were not examined by Field, received only a few cores each to explore for potential sand resources.

47. Specific core locations were selected based on several factors. First, the candidates for primary borrow sites were to receive the largest number of cores each. After that, size and offshore distance, plus preliminary results of geophysical data, determined the number of cores for remaining borrow sites. Exact positioning of cores on each shoal was based on bathymetry and geophysical data. This required recent, detailed, bathymetric surveys of borrow sites with local geographical coordinates superimposed. The objective was to locate cores in positions that would provide maximum sediment information to adequately represent an entire borrow site. Additionally, cores were used to determine lateral extent of shoal sands and to investigate unusual features noted in subbottom profile records. 


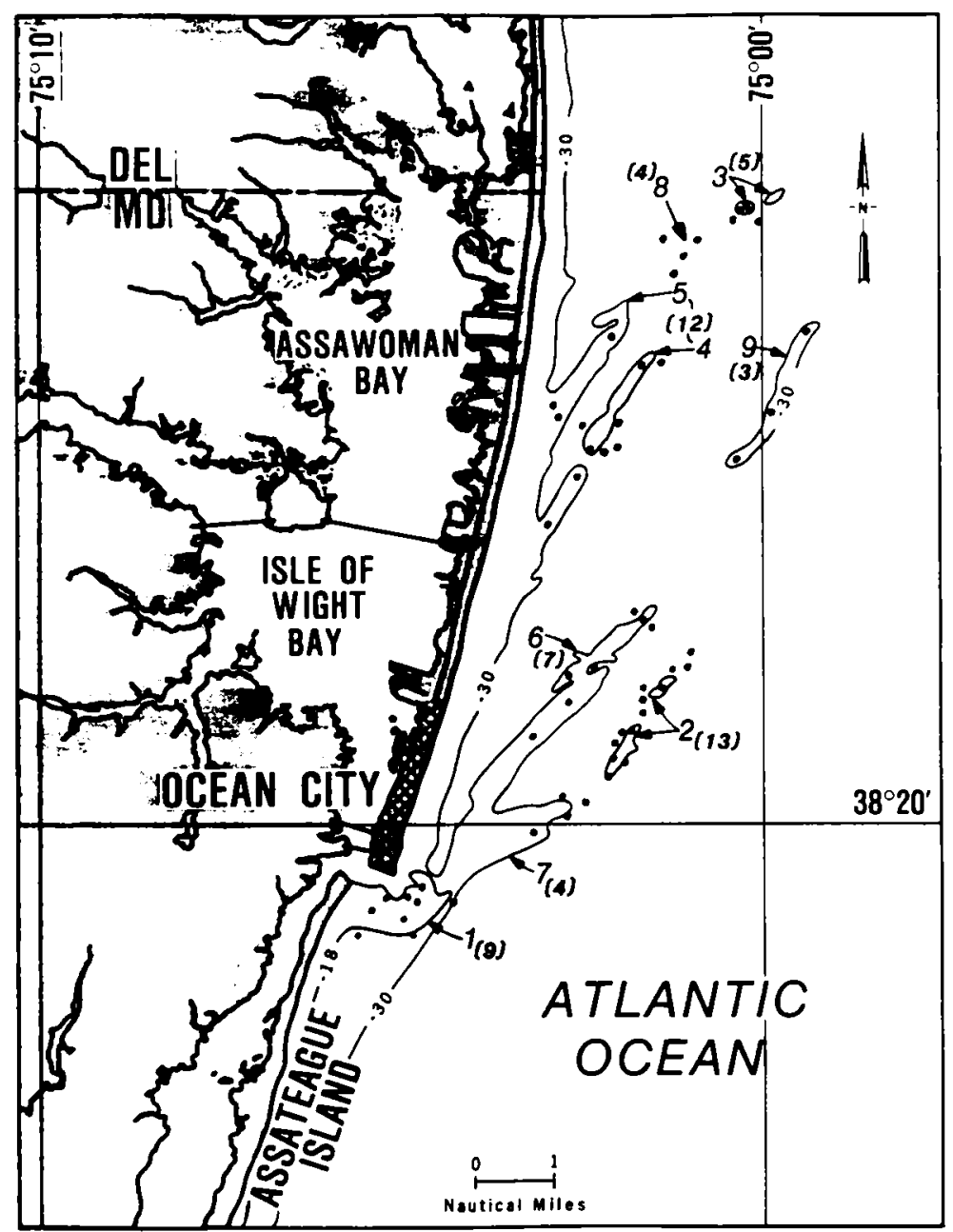

Figure 11. Approximate core locations on the shoals; $0=$ core location

48. Few guidelines are offered as to how many cores should be collected and how long they should be to characterize a borrow site. Initial plans at Ocean City were to collect 60 cores, each $40 \mathrm{ft}$ long, over nine shoals. However, costs for obtaining cores of that length resulted in a change to a combination of 30 - and 20 -ft-long cores. In retrospect, given approximately $20 \mathrm{ft}$ of water depth, $30 \mathrm{ft}$ is probably the maximum core length necessary since usual dredging technology generally does not allow cost-effective dredging below approximately $50 \mathrm{ft}$ of water depth. In the field, collection of 30-ft cores was impractical given rough sea conditions of the open Atlantic. Cores longer than $20 \mathrm{ft}$ are possible but would require a window of calm conditions, which did not occur during CERC's field operations. Experience showed that as wave height approached about $5 \mathrm{ft}$, safe, effective coring had to be 
terminated. For 30 - or $40-\mathrm{ft}$ cores, a safe wave height would have to be approximately $3 \mathrm{ft}$ or less.

49. Core length influenced location of cores on borrow sites. Since many sites had a local relief greater than $20 \mathrm{ft}$, a core on the crest could not be expected to penetrate the entire shoal thickness. Therefore, cores had to be collected on shoal flanks and in adjacent troughs. Together with geophysical data, this allowed projection of sedimentary units across the borrow site (Figure 12). Long after coring was completed, a decision was made to dredge down only to the level of surrounding topography. Had this decision been made prior to field work, it would have eliminated need to take cores on the lower shoal flanks and in troughs adjacent to shoals. These cores could have been relocated to give more information about actual dredge sites.

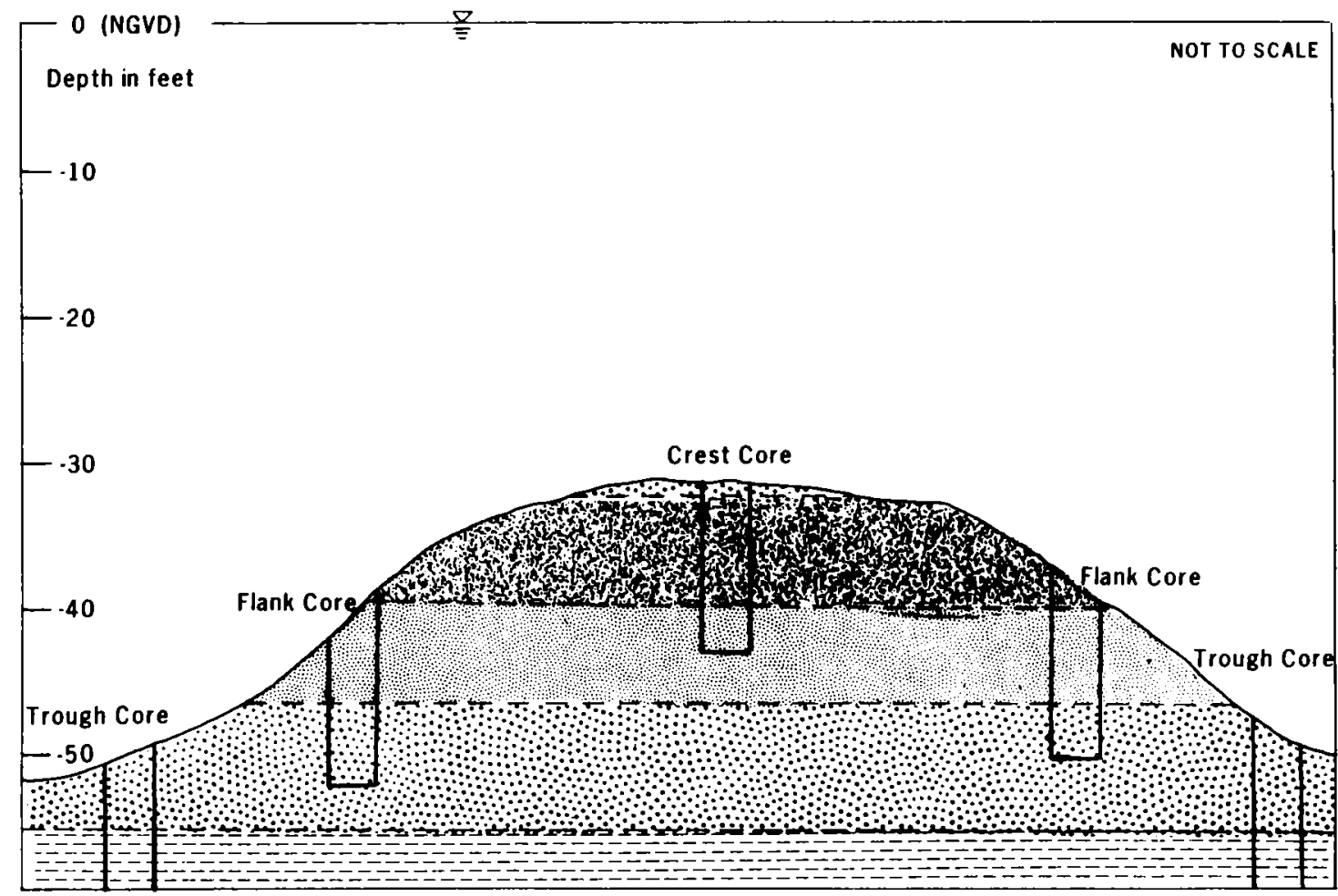

Figure 12. Hypothetical shoal cross section showing core locations for determining internal stratigraphy

50. A total of 36 vibracores were collected in mid-August at Ocean City, and an additional 21 cores were collected in early November 1986 . The November collection was required when the contractor defaulted in August because of an inability to collect cores in water less than $30 \mathrm{ft}$ deep. In both cases, an Alpine vibracorer, with an overall length of $27 \mathrm{ft}$ and core barrel length of $20 \mathrm{ft}$ with a 3-7/8-in.-diam core tube, was used. A 
crane/winch was used to lift the coring rig and place it on the bottom. Once in place, approximately 150 psi of compressed air were fed to the vibracore to start vibrating action. Vibrations combined with the instrument weight drove the core barrel into the sediment. An attached penetrometer displayed core penetration into the substrate. Once fully penetrated, the core barrel and vibracore rig were extracted and returned to the boat. On deck, the core barrel was disassembled, and the enclosed plastic core liner was removed. A new liner was reassembled into the rig for the next core. Each 20 -ft-long core was cut into metre-long sections, and each section was marked and sealed. These sections were returned to the laboratory for analysis. In some instances, penetration refusal was met before full penetration of sediment was achieved. Refusal was loosely defined in the field when penetration rate was less than $1 \mathrm{ft}$ per $5 \mathrm{~min}$. When total penetration was less than $15 \mathrm{ft}$, the vibracore was removed, and the short core was extracted and stored. A new liner was installed, and the vibracorer was returned to the seafloor. The core barrel was hydraulically jetted down to depth of refusal; then regular vibracoring resumed to a depth of $20 \mathrm{ft}$. When initial penetration was between 15 and $19 \mathrm{ft}$, the geologist onsite evaluated core contents and determined if additional length of core was necessary.

51. Location of field coring sites was accomplished using Loran $C$ fixes and either a Del Norte or Mini-Ranger locational system. Loran C coordinates determined from nautical charts and detailed bathymetric surveys of borrow sites were used to get the coring vessel approximately onsite. In most instances, intended core sites selected from maps and charts did not have to be located exactly in the field. If samples were being collected on a 1,140 -ft grid, accuracy to within $\pm 100 \mathrm{ft}$ would probably be sufficient. Accuracy greater than $50 \mathrm{ft}$ on a rolling sea is a time-consuming process. However, once an intended field coring site is located, its exact position should be determined. At Ocean City, exact positions of core sites were fixed using one of the location systems.

52. Cores were located on the crest of shoals at intersections of geophysical transect lines. Additional cores were located on flanks of shoals along the same geophysical transects. Table 3 shows the number of cores collected at each borrow site and approximate area of the site. Borrow sites 1 through $4 / 5$ were sampled at densities ranging from 1 core/2,500,000 $\mathrm{ft}^{2}$ to 
Table 3

Core and Borrow Site Data

\begin{tabular}{|c|c|c|c|c|c|c|}
\hline $\begin{array}{l}\text { Shoal/ } \\
\text { Borrow } \\
\text { Site } \\
\end{array}$ & $\begin{array}{l}\text { Mean } \\
\text { Size } \\
\text { phi } \\
\end{array}$ & $\begin{array}{l}\text { Approx. } \\
\text { Area } \\
\mathrm{ft}^{2} \times 10^{6}\end{array}$ & $\begin{array}{l}\text { No. of } \\
\text { Cores } \\
\text { Taken } \\
\end{array}$ & $\begin{array}{c}\text { Area } \\
\text { per Core } \\
\mathrm{ft}{ }^{2} \times 10^{6} \\
\end{array}$ & $\begin{array}{l}\text { No. of } \\
\text { Cores } \\
\text { Req. } \\
\end{array}$ & $\begin{array}{l}\text { Area per } \\
\text { Core Req. } \\
\mathrm{ft} \mathrm{t}^{2} \times 10^{6} \\
\end{array}$ \\
\hline \multicolumn{7}{|c|}{ Primary Sites $(d=0.25$ phi, Confidence $=95 \%)$} \\
\hline 1 & 2.02 & 27.9 & 9 & 3.1 & 14 & 2.0 \\
\hline 2 & 1.98 & 39.0 & 13 & 3.0 & 7 & 5.6 \\
\hline 3 & 0.90 & 18.9 & $4 *$ & 4.7 & 15 & 1.3 \\
\hline $4 / 5$ & 2.09 & 29.8 & 12 & 2.5 & 9 & 3.3 \\
\hline \multicolumn{7}{|c|}{ Exploratory Sites $(d=0.5$ phi, Confidence $=958)$} \\
\hline 6 & 2.14 & 60 & 7 & 8.5 & 4 & 15 \\
\hline 7 & 2.32 & 40 & 4 & 10.0 & 1 & 40 \\
\hline 8 & 2.10 & 20 & $3 *$ & 6.7 & 1 & 20 \\
\hline 9 & 1.74 & 30 & 3 & 10.0 & 10 & 3 \\
\hline
\end{tabular}

* One core from this site was not used in this analysis since it was located some distance away from the shoal crest or flanks.

1 core/4,700,000 $\mathrm{ft}^{2}$ of surface area. No guidelines currently exist on which to examine the usefulness of this coring density. To examine this problem, Ocean City core data were used as a test set, in the way beach samples were used to determine sample size, to determine required number of cores to characterize mean grain size of a borrow site. It is emphasized that these numbers are rough estimates, are specifically applicable only in cases similar to Ocean City where borrow sites are linear shoals located offshore, and assume lateral continuity of sediments between core locations. Using only upper sand bodies in each core, mean grain size and standard deviation of each borrow site were calculated from grain size data in each core. One core each from shoals 3 and 8 were eliminated from analysis because they were located in a trough alongside the borrow site and sediment was not considered representative of the borrow area. The number of cores required in each case, to be accurate to within 0.25 phi of true mean grain size of borrow sites 95 percent of the time, is listed in Table 3. Comparing the required number of cores to shoal area gives a range of required core density on primary borrow sites from 
1 core/1,300,000 $\mathrm{ft}^{2}$ to 1 core/5,600,000 $\mathrm{ft}^{2}$. As noted with beach samples, coarsest sediments tend to be most variable in grain sizes and therefore require more samples to accurately represent the mean. If borrow site grain size variation were not known in advance, the worst case would have to be accepted, which at Ocean City would be 1 core/1,300,000 $\mathrm{ft}^{2}$. That corresponds to a sampling grid of roughly $1,140 \mathrm{ft}$ between core locations.

53. Shoals 6 through 9 were explored for possible borrow site sand sources. These cores were generally located near shoal crests. Coring density was lower than on primary sites, ranging from 1 core/10,000,000 $\mathrm{ft}^{2}$ to 1 core/6,700,000 $\mathrm{ft}^{2}$. Cores from these sites were used as test samples to determine rough numbers of cores required to characterize the mean of surficial sand units in each site to within 0.5 phi, 95 percent of the time. Required numbers of cores are presented in Table 3, along with coring density. Shoal 9 is the worst case; however, since only three samples were collected from this site, the few degrees of freedom in Equation 3 dramatically raises the number of samples. Data from shoal 6 might be a more representative case of coring density required for exploration purposes. In this case, one core would be required on a grid interval of approximately $3,850 \mathrm{ft}$.

54. Coring density presented here should be considered only as preliminary estimates. Results are specific to borrow site conditions at Ocean City and are further limited by the small data set on which calculations were based. A similar analysis needs to be performed on a borrow site that has had dense sampling. At best, these numbers should be treated as approximate values. Clearly, additional research needs to be completed to establish acceptable guidelines for borrow site core collection. 
PART III: DATA ANALYSIS

\section{Laboratory Analysis}

\section{Beach sediment}

55. All native beach samples collected at Ocean City were taken to CERC's sediment analysis laboratory. However, not all samples collected were analyzed. As anticipated in the MOA, spatial variation in grain size of native beach sediment was small; therefore, it was sufficient to analyze only a representative portion of samples. The berm crest, midforeshore, beach step, $-2 \mathrm{ft}$, and $-6 \mathrm{ft}$ samples (Figure 6) were analyzed for all survey lines. However, the midberm samples and all samples seaward of $-6 \mathrm{ft}$ were only analyzed for every third profile line, starting with line one. Examination of short cores frequently produced several samples from each core for analysis, one from each distinct sediment horizon. A total of 398 core and surface grab samples were processed. Complete sediment analysis included determination of grain size parameters for the sand fraction and silt/clay (mud) content of each sample. Percentage of carbonates (shell material) was randomly checked.

56. Laboratory procedure began with determination of mud (less than 4 phi size) percentages. Field samples were air dried and split to approximately 2 oz (50 to $60 \mathrm{~g}$ ). Samples were washed with demineralized water over a 230-mesh sieve to separate mud from sand (Figure 13). The resulting slurry of mud was placed in a vacuum pump, and residue left on $0.4 \times 10^{-5}$ in. $^{2}$ filter was dried, weighed, and compared with initial sample weight to determine percentage of mud. Sieving separation, hydrometer analysis, and pipette analysis are alternative methods for determining percent mud. Carbonate content was determined for a few selected samples by treating preweighed samples with a 20 -percent solution of hydrochloric acid. Comparison of preweight and postweight determined percentage of carbonates, which was generally found to be negligible.

57. Grain size analysis of the sand fraction was the final step after mud and carbonate determinations were completed. Analysis was performed using a dry sieving technique, as outlined in Folk (1980). The methodology employed a sonic sifter and was almost fully automated. A sonic sifter uses sound waves to enhance shaking motion of sand grains, thus allowing faster sieving times and smaller initial samples (Underwood 1988). A total of 24 sieves with 


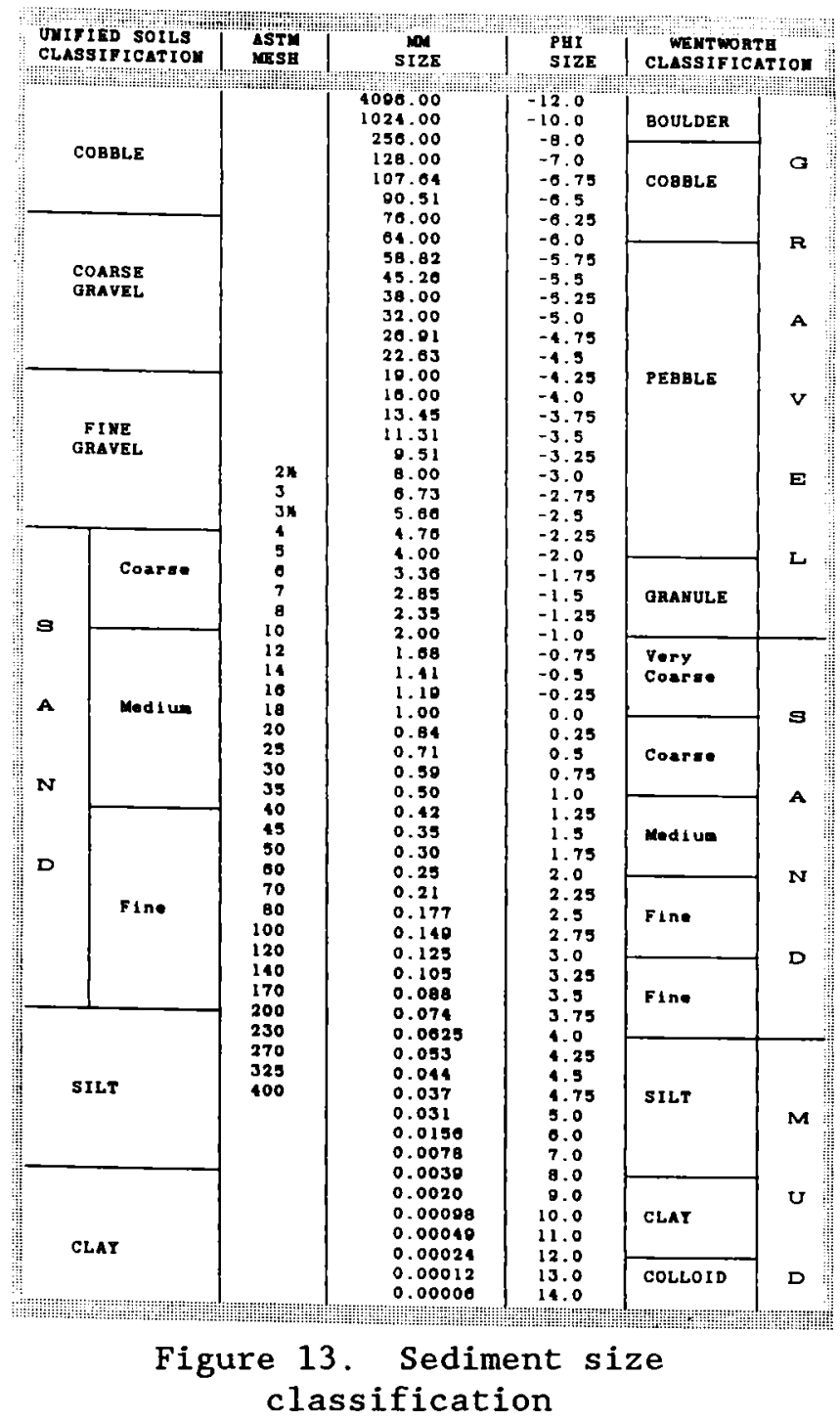

a 0.25 phi interval and a range from -2.0 phi to 4.0 phi were used with every sample. Complete sieve analysis could be run on the sonic sifter faster than a run of 1 sieve stack on a conventional sieve shaker. Final sediment statistics were calculated using both methods of moments and graphical techniques.

58. Past beach nourishment projects have generally used Folk's (1980) graphical techniques to calculate mean and standard deviation. This procedure is quicker than hand calculation of moments; however, its ability to accurately characterize mean and standard deviation is limited since it uses only a few points from the entire data distribution. The method of moments, however, uses data from the entire weight distribution and is, therefore, more accurate. In the past, this method was not widely used because of lengthy calculations. With the advent of scientific calculators and computers, this calculation has become simple. Graphical measures were calculated for Ocean 
City only for comparison to previous data sets. All analyses were based on grain size statistics calculated by method of moments. In a comparison of 225 samples from Ocean City, graphical mean agreed with the more accurate moment mean only 36 times, and graphical standard deviation agreed with moment deviation 24 times.

Borrow site sediment

59. Geophysical data. Limited attention was given to side-scan sonar data. Little additional information could be obtained from side-scan records that was not already available from subbottom records and cores. Examination of signal intensity and wave patterns showed only that the shoal surface was mobile.

60. Subbottom profiler records, which are cross sections through a borrow site, were interpreted to evaluate lateral extent, orientation, continuity, and thickness of usable sands within and beneath borrow site shoals. Records were assembled for each shoal and adjusted to allow uniform orientation. Sediment layers were identified in conjunction with core log data and previous research. Pertinent information was measured at each time mark on records and was used later to generate sediment maps of borrow sites.

61. Figure 14 represents a portion of a typical subbottom profiler record at Ocean City. The first identifiable feature is the seabed. Below are horizons or reflectors resulting from some change in acoustic properties of sediment. Typically, these result from one distinct sediment type such as sand, overlying a second, different sediment type such as clay. Lithology of sand units can be distinguished on good records where cross-bedding and other internal structures are visible. However, geophysical records alone cannot distinguish sand grain sizes. At Ocean City, the quality of records was generally not good enough to determine sediment type, but they were useful for quantitative measurement of bed thickness, extent, and orientation. A third feature seen on cross sections is the seabed multiple, which is a second return of energy from the seabed. In this case, the multiple marks the bottom of usable data since it obscures the remaining record. Occurrence of a multiple is a significant problem in shallow-water surveys.

62. Vibracore data. In the laboratory, 1-m-long vibracore sections were cut in half longitudinally. A detailed visual examination of each core was conducted, and a descriptive core $10 \mathrm{~g}$ was completed noting thicknesses of specific horizons, approximate grain sizes, sediment composition, textures, 


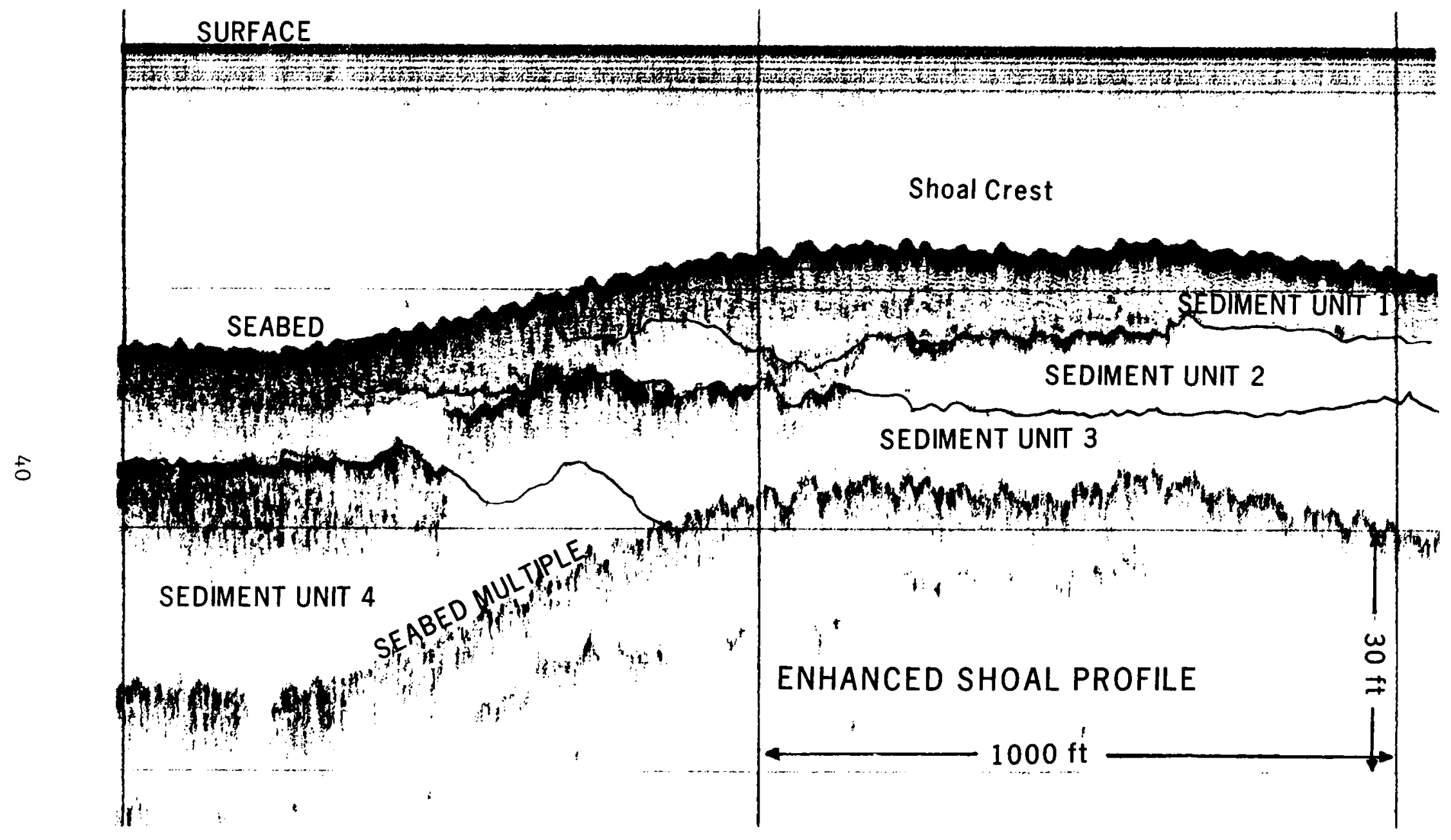

Figure 14. Subbottom profile record from the potential borrow sites 
sorting, sedimentary structures, flora and fauna, and other core properties (Figure 15). Sand units in one core half were sampled by collecting a continuous channel sample through its entire length. Samples were analyzed in the laboratory for grain size distribution following procedures outlined above for analysis of beach samples. Sampled core halves were thoroughly dissected, looking for additional information not visible on exposed surfaces. Unsampled core halves were photographed and sealed in plastic for storage by DNR.

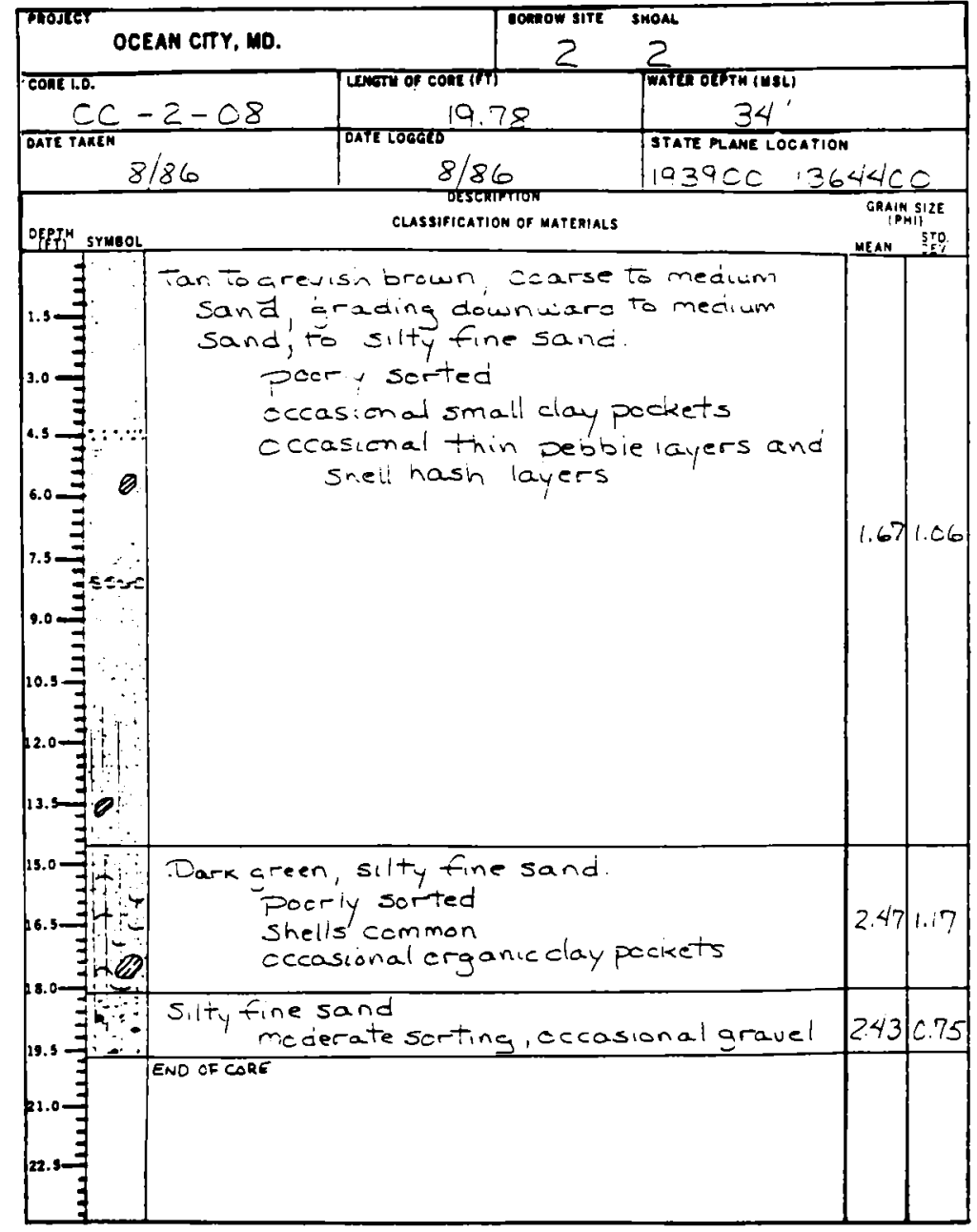

Figure 15. Core $\log$ from a potential borrow site

\section{Analysis of Laboratory Data}

\section{Native beach}

63. Information obtained from analysis of all native beach samples collected included plots of beach profiles with sample locations noted, plots 
of mean grain size versus distance offshore, a data sheet for all 398 samples, cumulative weight percent distribution for each sample, and a data summary. Only the data summary is included in this report (Appendix A).

64. Grain size distribution. Typically, beaches have their coarsest sediment at the step, which coincides with breaking waves on the foreshore. From the step, sediment generally fines in both offshore and onshore directions. Along most mid-Atlantic beaches, sediment seaward of the offshore bar are fine sand to clay size. Between the bar and step, there is usually sand size material, and the foreshore has sand to gravel.

65. At Ocean City, a total of 8 percent of samples had mean grain sizes qualifying them as very coarse sand or gravel (Wentworth Classification (WC)). Most were from the subaerial beach. Less than 3 percent of subaerial samples were 2.0 phi (fine sand, WC) or smaller. Fifty-five percent of all subaqueous samples were fine or very fine (WC) sand. Most of these were located seaward of the offshore bar. This agrees with general models of fining sediment in both directions from the beach step with finest sediment in offshore segments of profiles and coarsest sediment on the beach face. Both subaerial and subaqueous samples were generally moderately sorted. Over 75 percent of all samples were negatively skewed. A negative skewness indicates sediment distribution is asymmetrically tailed toward coarse grain sizes.

66. Sampling plan. Ideally, a native beach should be spatially sampled many times throughout a several-year period to fully represent all sedimentological conditions. This type of collection plan was not possible for Ocean City; instead, a one-time collection was performed using cores to represent temporal variations. Consideration had to be given to methods for use of core data in composite grain size calculations. Different sampling procedures and weighing schemes of individual core samples will alter a native beach composite. The procedure selected assumed each discrete layer of sediment in a core represented the beach surface at some unknown time interval. A sample from each layer was therefore equivalent to a grab sample collected at that unknown time. Wide varieties of grain sizes present in cores represent a complete temporal range of sizes available for surface exposure. The averaging method used to form core composites assumed equal weighing for each core sample. This method weighs higher energy events evenly with typical moderate to low energy periods. Lack of a similar offshore temporal data set tends to bias composites toward coarse beach samples; however, greater numbers of 
offshore samples (seven versus four per sample line) minimizes coarsening effects. The end result is definition of a sample population representative of the complete spatial and temporal grain size range.

67. Composite technique. Composite beach grain size was calculated by taking weights retained on each individual sieve for each sample and averaging those weights. The result is an average weight retained for each sieve. For example, weight retained on the 1 phi sieve in all 396 samples was averaged. This was repeated for each sieve to define a weight distribution for the composite sample. Mean and standard deviation calculated from this weight distribution are representative of the entire beach. Straight averaging of each individual sample mean and deviation would result in a mean similar to the composite mean, but average standard deviation would be incorrect since variation in sample range would not be fully represented.

68. At Ocean City, examination of beach data as a composite sample yields a mean grain size of 1.84 phi with a standard deviation of 1.22 phi. This falls within medium (WC) or fine (Unified Soils Classification (USC)) sand (Figure 13). Standard deviation is a measure of dispersion of data around a mean and can be used as an index of sediment sorting. Using a classification devised by Folk (1980), composite samples would be designated poorly sorted. This implies dispersion of grain sizes is quite large, which is expected when combining sediment populations from zones of different energy.

\section{Borrow sites}

69. A brief summary of information, including core and grain size data, for each potential borrow site investigated follows. Complete grain size data are presented in Appendix $B$.

70. Borrow site 1 . Borrow site 1 is composed entirely of shoal 1 , the ebb-tidal delta of Ocean City inlet. The shoal is crescent shaped, extending east and north from northern Assateague Island. Distal shoal portions are about $1 \mathrm{n} . \mathrm{m}$. from southern Ocean City (Figure 4). A total of nine vibracores and 14.7 miles of subbottom profiles were collected over borrow site 1 . Very shallow water (less than $5 \mathrm{ft}$ ) made this a difficult site for data collection and prevented sampling over the immediate crest.

71. Examination of core sediment generally showed sands overlying clay or peat. Texture and thickness of sand units varied (Table 4). Sand sizes of 
Table 4

Summary of Vibracore Analysis for Borrow Site 1

\begin{tabular}{|c|c|c|c|c|c|c|c|}
\hline $\begin{array}{l}\text { Core } \\
\text { No. }\end{array}$ & $\begin{array}{c}\text { Location } \\
\text { State Plane } \\
\mathrm{ft}\end{array}$ & $\begin{array}{l}\text { Descriptive } \\
\text { Location } \\
\text { \& Depth, ft }\end{array}$ & $\begin{array}{c}\text { Max. Sand } \\
\text { Thickness } \\
\mathrm{ft} \\
\end{array}$ & $\begin{array}{l}\text { Mean } \\
\text { Size } \\
\text { phi }\end{array}$ & $\begin{array}{c}\text { Stand. } \\
\text { Dev. } \\
\text { phi } \\
\end{array}$ & $\begin{array}{l}\text { Skew } \\
\text { phi }\end{array}$ & $\begin{array}{c}\text { Mud } \\
8 \\
\end{array}$ \\
\hline 1 & $\begin{array}{r}180,200 \\
1,346,900\end{array}$ & $\begin{array}{l}\text { S. Flank } \\
22\end{array}$ & 7.2 & $\begin{array}{l}2.84 \\
\text { fine }\end{array}$ & 0.66 & -0.6 & 4.3 \\
\hline 2 & $\begin{array}{r}182,500 \\
1,350,700\end{array}$ & N. Flank & 13.1 & $\begin{array}{l}2.31 \\
\text { fine }\end{array}$ & 0.56 & -1.0 & 0.2 \\
\hline \multirow[t]{2}{*}{3} & $\begin{array}{r}182,350 \\
1,347,800\end{array}$ & $\begin{array}{l}\text { N. Flank } \\
13\end{array}$ & 4.8 & $\begin{array}{l}1.80 \\
\text { med. }\end{array}$ & 0.80 & -0.6 & $\begin{array}{l}0.1- \\
1.9\end{array}$ \\
\hline & & & 6.0 & $\begin{array}{l}2.24 \\
\text { fine }\end{array}$ & 1.05 & 0.0 & $\begin{array}{l}3.2- \\
17.6\end{array}$ \\
\hline 4 & $\begin{array}{r}180,050 \\
1,350,050\end{array}$ & $\begin{array}{l}\text { S. Flank } \\
23\end{array}$ & 11.0 & $\begin{array}{l}2.11 \\
\text { fine }\end{array}$ & 0.70 & -0.2 & $\begin{array}{l}0.1- \\
0.7\end{array}$ \\
\hline 5 & $\begin{array}{r}181,500 \\
1,349,200\end{array}$ & $\begin{array}{c}\text { Crest } \\
7\end{array}$ & 8.9 & $\begin{array}{l}1.63 \\
\text { med. }\end{array}$ & 0.73 & -2.0 & 0.0 \\
\hline 6 & $\begin{array}{r}182,500 \\
1,349,000\end{array}$ & N. Flank & 12.9 & $\begin{array}{l}1.42 \\
\text { med. }\end{array}$ & 0.70 & -0.2 & 0.0 \\
\hline \multirow[t]{2}{*}{7} & $\begin{array}{r}180,200 \\
1,352,000\end{array}$ & S. Trough & 4.6 & $\begin{array}{l}2.65 \\
\text { fine }\end{array}$ & 0.78 & -1.2 & 2.3 \\
\hline & & & 5.3 & $\begin{array}{l}2.35 \\
\text { fine }\end{array}$ & 1.03 & -1.0 & $\begin{array}{l}10.6 \\
11.4\end{array}$ \\
\hline 8 & $\begin{array}{r}183,550 \\
1,350,800\end{array}$ & $\begin{array}{l}\text { N. Trough } \\
22\end{array}$ & 17.5 & $\begin{array}{l}1.89 \\
\text { med. }\end{array}$ & 0.59 & -0.6 & $\begin{array}{l}0.0- \\
0.1\end{array}$ \\
\hline 9 & $\begin{array}{r}182,600 \\
1,350,300\end{array}$ & $\begin{array}{l}\text { N. Flank } \\
15\end{array}$ & 15.1 & $\begin{array}{l}1.49 \\
\text { med. }\end{array}$ & 0.69 & -0.2 & 0.1 \\
\hline
\end{tabular}

individual units within cores ranged from coarse ( 0.59 phi) to very fine ( $3.38 \mathrm{phi}$ ). All sand was moderately to poorly sorted, with negative skewness. This indicates a wide distribution of grain sizes within each core. Mud content of surface sands ranged between 0 and 4.3 percent. In cores 1-3 and 1-7, additional sand layers were found at depth. These layers were separated from overlying sands by a thick clay layer ( $+1 \mathrm{ft}$ ). In both cases, additional sands were in the fine sand classification and exceeded 11 -percent mud content. 
72. An isopach map (Figure 16) was developed showing maximum thickness of borrow site sand as determined from cores and interpretation of geophysical cross sections. Over $20 \mathrm{ft}$ of sand is present on the east end of the shoal. A large portion of the north side is in excess of $10 \mathrm{ft}$ of sand. Sand in this area thins gradually toward the shoreline and inlet channel. Data from cores suggest much of this sand is medium size. It was intended that the isopach map be used by NAB and DNR in planning for dredging. Combined with a map showing spatial distribution of borrow site grain sizes, this would provide detailed information on where best grain sizes are located and how thick deposits of borrow material are at any point.

73. Borrow site 2. Borrow site 2 is composed entirely of shoal 2, which is located about $2 \mathrm{n} . \mathrm{m}$. east of southern Ocean City (Figure 4). A total of 13 vibracores and 49.9 track miles of subbottom profile were collected over this borrow site. Bathymetric data indicated this large shoal was linear, extending in a NNE to SSW direction. Three distinct crests are found on the main shoal morphology. Cores were collected over crests and along the flanks. Minimum water depth is approximately 30 to $35 \mathrm{ft}$.

74. Sand within each core varied in grain size. Mean grain size for all cores fell between fine to medium sand (Table 5), but within any core, discrete units had means ranging from very coarse sand ( -0.14 phi) to very fine sand ( $3.0 \mathrm{phi})$. Most cores showed a thick sequence of sand overlying silt and clay rich sediments.

75. As expected, maximum thickness of borrow is roughly coincident with the shoal crest. Sand size sediments appear to be over $30 \mathrm{ft}$ thick in one location and over $20 \mathrm{ft}$ thick along the entire shoal crest. Cores 2-4, 2-5, 2-8, 2-9, and 2-11 contain medium sands. All of these cores are located on the northwest flank, near the crest. They vary in sand thickness from 8.6 to $19.8 \mathrm{ft}$, and all except core $2-8 \mathrm{had}$ mud contents of less than 10 percent. Remaining cores are composed of fine sand. Percent mud varied from 0 to 40.4 percent. Fine-grained cores were distributed on the southeast flank, crest area, and northwest flank. Those on the southeast flank had finest grain sizes. Most cores were moderately sorted, and all had a negative skewness.

76. Borrow site 3. Borrow site 3 , composed entirely of shoal 3 , is located about $3 \mathrm{n} . \mathrm{m}$. east of Ocean City and straddles the Maryland/Delaware State border (Figure 4). This site, as defined by a January 1986 bathymetric 


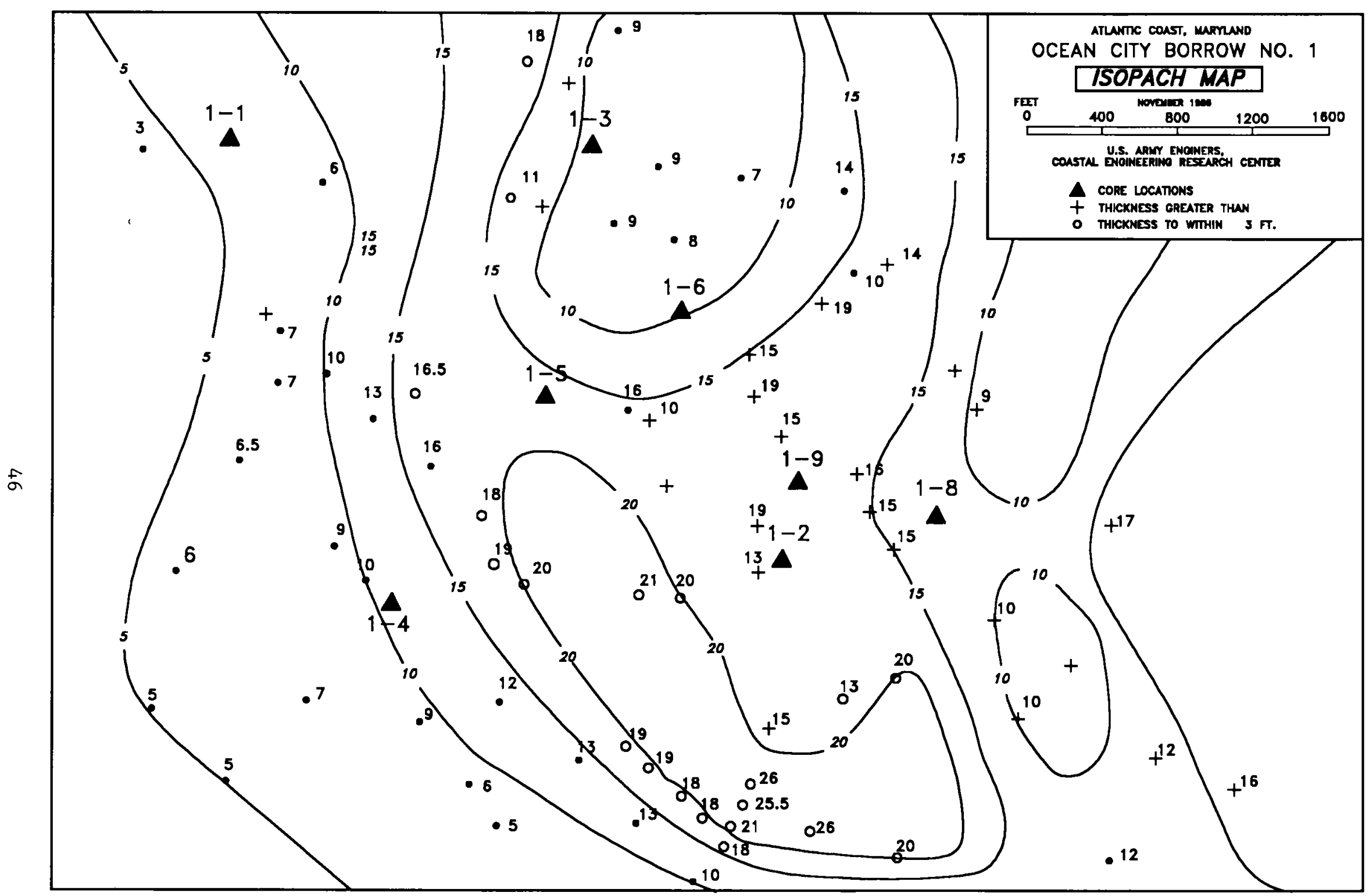

Figure 16. Isopach map of sand thickness in shoal/borrow site 1 
Table 5

Summary of Vibracore Analysis for Borrow Site 2

\begin{tabular}{|c|c|c|c|c|c|c|c|}
\hline $\begin{array}{l}\text { Core } \\
\text { No. }\end{array}$ & $\begin{array}{c}\begin{array}{c}\text { Location } \\
\text { State Plane } \\
\mathrm{ft}\end{array} \\
\end{array}$ & $\begin{array}{l}\text { Descriptive } \\
\text { Location } \\
\underline{\text { \& Depth } \mathrm{ft}}\end{array}$ & $\begin{array}{c}\text { Max. Sand } \\
\text { Thickness } \\
\mathrm{ft} \\
\end{array}$ & $\begin{array}{l}\text { Mean } \\
\text { Size } \\
\text { phi } \\
\end{array}$ & $\begin{array}{c}\text { Stand. } \\
\text { Dev. } \\
\text { phi }\end{array}$ & $\begin{array}{l}\text { Skew } \\
\text { phi }\end{array}$ & $\begin{array}{c}\text { Mud } \\
8 \\
\end{array}$ \\
\hline 1 & $\begin{array}{r}200,250 \\
1,369,050\end{array}$ & S. Crest & 19.5 & $\begin{array}{l}2.18 \\
\text { fine }\end{array}$ & 1.11 & -0.8 & $\begin{array}{r}2.5 \\
27.7\end{array}$ \\
\hline 2 & $\begin{array}{r}200,250 \\
1,369,500\end{array}$ & $\begin{array}{c}\text { Trough } \\
47\end{array}$ & 14.1 & $\begin{array}{l}2.20 \\
\text { fine }\end{array}$ & 0.82 & -1.0 & $\begin{array}{r}0.2 \\
10.6\end{array}$ \\
\hline 3 & $\begin{array}{r}197,800 \\
1,366,700\end{array}$ & N. Crest & 15.5 & $\begin{array}{l}2.07 \\
\text { fine }\end{array}$ & 0.56 & -1.2 & $\begin{array}{l}0.0 \\
0.8\end{array}$ \\
\hline 4 & $\begin{array}{r}201,600 \\
1,369,100\end{array}$ & N. $\underset{44}{\text { Flank }}$ & 19.6 & $\begin{array}{l}1.82 \\
\text { med. }\end{array}$ & 0.93 & -0.6 & $\begin{array}{l}0.5 \\
9.4\end{array}$ \\
\hline 5 & $\begin{array}{r}196,200 \\
1,366,200\end{array}$ & N. $\begin{array}{l}\text { Flank } \\
37\end{array}$ & 17.1 & $\begin{array}{l}1.95 \\
\text { med. }\end{array}$ & 0.54 & -1.2 & 0.1 \\
\hline 6 & $\begin{array}{r}196,200 \\
1,365,400\end{array}$ & N. $\underset{44}{\text { Flank }}$ & 18.5 & $\begin{array}{l}2.10 \\
\text { fine }\end{array}$ & 0.93 & -1.2 & $\begin{array}{r}0.1 \\
10.7\end{array}$ \\
\hline 7 & $\begin{array}{r}194,500 \\
1,365,550\end{array}$ & $\begin{array}{c}\text { Crest } \\
33\end{array}$ & 19.0 & $\begin{array}{l}2.06 \\
\text { fine }\end{array}$ & 6.44 & -0.6 & $\begin{array}{l}0.1 \\
1.8\end{array}$ \\
\hline 8 & $\begin{array}{r}193,900 \\
1,364,400\end{array}$ & N. Crest & 19.8 & $\begin{array}{l}1.88 \\
\text { med. }\end{array}$ & 1.06 & -0.8 & $\begin{array}{r}2.5 \\
14.0\end{array}$ \\
\hline 9 & $\begin{array}{r}193,950 \\
1,364,450\end{array}$ & N. $\begin{array}{l}\text { F1 ank } \\
34\end{array}$ & 12.6 & $\begin{array}{l}1.16 \\
\text { med. }\end{array}$ & 0.61 & -0.6 & 0.1 \\
\hline 10 & $\begin{array}{r}193,100 \\
1,365,850\end{array}$ & S. Flank & 20.0 & $\begin{array}{l}2.38 \\
\text { fine }\end{array}$ & 0.75 & -1.2 & $\begin{array}{r}0.5 \\
22.5\end{array}$ \\
\hline 11 & $\begin{array}{r}193,350 \\
1,364,450\end{array}$ & N. $\begin{array}{l}\text { Crest } \\
31\end{array}$ & 8.6 & $\begin{array}{l}1.35 \\
\text { med. }\end{array}$ & 0.84 & -1.0 & $\begin{array}{l}0.0 \\
0.2\end{array}$ \\
\hline 12 & $\begin{array}{r}190,050 \\
1,362,300\end{array}$ & $\begin{array}{l}\text { S. Flank } \\
42\end{array}$ & 19.7 & $\begin{array}{l}2.41 \\
\text { fine }\end{array}$ & 0.88 & -0.8 & $\begin{array}{r}2.0 \\
40.4\end{array}$ \\
\hline 13 & $\begin{array}{r}197,100 \\
1,366,700\end{array}$ & S. $\begin{array}{l}\text { Crest } \\
34\end{array}$ & 16.4 & $\begin{array}{l}2.22 \\
\text { fine }\end{array}$ & 0.61 & -1.4 & $\begin{array}{l}0.2 \\
6.7\end{array}$ \\
\hline
\end{tabular}


survey, has two distinct crests, one of which lies entirely within Maryland. A total of five vibracores and approximately 20 miles of geophysical data were collected. Cores were collected in the vicinity of Maryland's crest and along its flanks. Water depth over the crest is approximately 30 to $35 \mathrm{ft}$.

77. Sand present in this borrow site varies from very fine on its flanks to coarse near the crest (Table 6). All three cores on the crest and north flank were composed entirely of coarse sand with less than 1-percent mud content. South flank and trough cores were composed of medium to fine sands with up to 13 -percent mud. Of all sites examined, this borrow area appeared to have a larger percentage of clean, coarse sand. These sands were moderately well sorted with a negative skewness. More than a 20 -ft thickness of sand is available from this borrow site.

Table 6

Summary of Vibracore Analysis for Borrow Site 3

\begin{tabular}{|c|c|c|c|c|c|c|c|}
\hline $\begin{array}{l}\text { Core } \\
\text { No. }\end{array}$ & $\begin{array}{c}\text { Location } \\
\text { State Plane } \\
\mathrm{ft} \\
\end{array}$ & $\begin{array}{l}\text { Descriptive } \\
\text { Location } \\
\text { \& Depth. ft } \\
\end{array}$ & $\begin{array}{l}\text { Max. Sand } \\
\text { Thickness } \\
\mathrm{ft} \\
\end{array}$ & $\begin{array}{l}\text { Mean } \\
\text { Size } \\
\text { phi } \\
\end{array}$ & $\begin{array}{l}\text { Stand. } \\
\text { Dev. } \\
\text { phi }\end{array}$ & $\begin{array}{l}\text { Skew } \\
\text { phi }\end{array}$ & $\begin{array}{c}\text { Mud } \\
8 \\
\end{array}$ \\
\hline 1 & $\begin{array}{r}231,300 \\
1,373,650\end{array}$ & $\begin{array}{l}\text { N. F1 ank } \\
32\end{array}$ & 21.9 & $\begin{array}{l}0.74 \\
\text { coarse }\end{array}$ & 0.92 & -0.2 & $\begin{array}{l}0.1- \\
0.2\end{array}$ \\
\hline 2 & $\begin{array}{r}230,500 \\
1,373,450\end{array}$ & $\begin{array}{c}\text { Crest } \\
30\end{array}$ & 18.6 & $\begin{array}{l}0.74 \\
\text { coarse }\end{array}$ & 0.95 & -0.4 & $\begin{array}{l}0.1 \\
0.3\end{array}$ \\
\hline 3 & $\begin{array}{r}231,400 \\
1,373,350\end{array}$ & $\begin{array}{l}\text { N. Flank } \\
35\end{array}$ & 11.4 & $\begin{array}{l}0.63 \\
\text { coarse }\end{array}$ & 0.90 & -0.6 & 0.1 \\
\hline 4 & $\begin{array}{r}229,650 \\
1,372,850\end{array}$ & S. Flank & 14.0 & $\begin{array}{l}1.50 \\
\text { med. }\end{array}$ & 0.98 & -0.6 & $\begin{array}{l}1.1- \\
11.9\end{array}$ \\
\hline 5 & $\begin{array}{r}231,450 \\
1,376,700\end{array}$ & $\begin{array}{l}\text { S. Trough } \\
41\end{array}$ & 18.6 & $\begin{array}{l}2.43 \\
\text { fine }\end{array}$ & 0.85 & -1.0 & $\begin{array}{l}0.2- \\
13.1\end{array}$ \\
\hline
\end{tabular}

\section{Borrow site 4}

78. Shoals 4 and 5 together comprise borrow site 4 for the project. A total of 12 cores and 42.8 miles of geophysical track were collected within this borrow area. A majority of cores were collected over shoal 4, a larger, more seaward shoal (Figure 4). Both shoals are shoreface connected at their southern ends, extending in a northeast direction to a point about 1-1/2 n.m. 
offshore. Borrow site 4 lies within the northern half of Ocean City. Water depth varies between 20 and $30 \mathrm{ft}$.

79. Vibracore and sediment data for borrow site 4 are summarized in Table 7. A majority of cores have fine sand. Examination of individual sand layers within each core shows a mean range from coarse ( 0.15 phi) to very fine sand ( $3.07 \mathrm{phi}$ ). Mud content of sand units ranged from 0.1 to over 50 percent. Sand thickness varied from only $1.7 \mathrm{ft}$ to over $19.9 \mathrm{ft}$. All cores were moderate to poorly sorted with negative skewness, indicating a large variety in grain sizes, especially within the coarse grains.

80. While a majority of cores showed an overall mean grain size in the fine sand range, a detailed examination of sand units in each core often revealed medium sands overlying fines. In core 4-5, for example, overall mean for $12.6 \mathrm{ft}$ of sand is $2.05 \mathrm{phi}$ (fine sand). However, mean of the first $11.4 \mathrm{ft}$ is $1.92 \mathrm{phi}$ (medium sand). Likewise, in five other cores (Table 8), a reexamination of upper horizons within sand units resulted in a change in mean grain sizes.

81. Maximum sand thickness in this borrow site exceeds $25 \mathrm{ft}$ in some locations; however, maximum thickness is not continuous along the shoal crest. Rather, it appears at specific crest locations. Examination of sediment data suggests coarse grain sizes are more likely to be found toward the north end of the borrow site.

82. Borrow site 6 . Borrow site/shoal 6 lies 1 to $2-1 / 2$ n.m. directly east of southern Ocean City, between the shoreline and borrow site 2 (Figure 4). This shoal is not a primary borrow site; however, field data indicate it has potential as a sand source. Bathymetric data were not obtained from this shoal, but data from nautical chart 12211 show a very elongate morphology with water depths of 14 to $20 \mathrm{ft}$ over the crest.

83. A total of seven vibracores (Table 9) were collected from shoal 6, along with 9.6 miles of geophysical data. Core data suggest medium sands over the crest and fine sands along flanks. These sands are moderately sorted with a negative skewness. Mud content ranged from 0 to 23 percent, with discrete layers of mud found in cores 6-2 and 6-4. A minimum of $20 \mathrm{ft}$ of sand covers most of the site, with coarser sediments near the crest and north flank.

84. Borrow site 7. Borrow site/shoal 7 lies south of shoal 6 and approximately 1 to $1-1 / 2 \mathrm{n} . \mathrm{m}$. east of southern Ocean City (Figure 4). Detailed bathymetric data were not available for this borrow site. This shoal 
Table 7

Summary of Vibracore Analysis for Borrow Site 4

\begin{tabular}{|c|c|c|c|c|c|c|c|}
\hline $\begin{array}{l}\text { Core } \\
\text { No. }\end{array}$ & $\begin{array}{c}\text { Location } \\
\text { State Plane } \\
\mathrm{ft}\end{array}$ & $\begin{array}{l}\text { Descriptive } \\
\text { Location } \\
\text { \& Depth ft }\end{array}$ & $\begin{array}{l}\text { Max. Sand } \\
\text { Thickness } \\
\mathrm{ft} \\
\end{array}$ & $\begin{array}{l}\text { Mean } \\
\text { Size } \\
\text { phi } \\
\end{array}$ & $\begin{array}{c}\text { Stand. } \\
\text { Dev. } \\
\text { phi }\end{array}$ & $\begin{array}{l}\text { Skew } \\
\text { phi }\end{array}$ & $\begin{array}{c}\text { Mud } \\
8\end{array}$ \\
\hline 4-1 & $\begin{array}{r}219,150 \\
1,365,250\end{array}$ & $\begin{array}{c}\text { Crest } \\
\quad 32\end{array}$ & 19.3 & $\begin{array}{l}2.25 \\
\text { fine }\end{array}$ & 0.67 & -1.2 & $\begin{array}{l}0.3- \\
3.6\end{array}$ \\
\hline $4-2$ & $\begin{array}{r}214,650 \\
1,365,150\end{array}$ & S. Flank & 19.9 & $\begin{array}{l}2.56 \\
\text { fine }\end{array}$ & 1.13 & -1.0 & $\begin{array}{l}0.8- \\
48.2\end{array}$ \\
\hline $4-3$ & $\begin{array}{r}214,600 \\
1,361,650\end{array}$ & N. $\begin{array}{l}\text { Flank } \\
40\end{array}$ & 10.8 & $\begin{array}{l}1.51 \\
\text { med. }\end{array}$ & 0.62 & -0.2 & $\begin{array}{l}0.3- \\
2.6\end{array}$ \\
\hline 4-4 & $\begin{array}{r}212,950 \\
1,363,050\end{array}$ & $\begin{array}{l}\text { S. Flank } \\
30\end{array}$ & 1.7 & $\begin{array}{l}2.53 \\
\text { fine }\end{array}$ & 1.49 & -1.6 & $\begin{array}{r}9.5- \\
59.1\end{array}$ \\
\hline 4-5 & $\begin{array}{r}213,700 \\
1,364,550\end{array}$ & $\begin{array}{l}\text { S. Flank } \\
30\end{array}$ & 12.6 & $\begin{array}{l}2.05 \\
\text { fine }\end{array}$ & 1.40 & -0.6 & $\begin{array}{l}2.3- \\
53.1\end{array}$ \\
\hline 4-6 & $\begin{array}{r}213,650 \\
1,361,950\end{array}$ & $\begin{array}{l}\text { S. Crest } \\
30\end{array}$ & 8.5. & $\begin{array}{l}2.62 \\
\text { fine }\end{array}$ & 0.56 & 0.0 & $\begin{array}{l}0.2- \\
12.6\end{array}$ \\
\hline 4-7 & $\begin{array}{r}209,050 \\
1,359,750\end{array}$ & $\begin{array}{c}\text { Crest } \\
29\end{array}$ & 11.7 & $\begin{array}{l}1.79 \\
\text { med. }\end{array}$ & 1.29 & -1.4 & 2.7 \\
\hline 4-8 & $\begin{array}{r}211,550 \\
1,361,450\end{array}$ & $\begin{array}{l}\text { S. Flank } \\
30\end{array}$ & 15.5 & $\begin{array}{l}2.11 \\
\text { fine }\end{array}$ & 0.81 & -0.8 & $\begin{array}{l}0.1- \\
6.9\end{array}$ \\
\hline $5-3$ & $\begin{array}{r}219,800 \\
1,367,900\end{array}$ & $\begin{array}{c}\text { Crest } \\
\quad 32\end{array}$ & 9.8 & $\begin{array}{l}1.96 \\
\text { med. }\end{array}$ & 0.80 & -1.4 & 0.5 \\
\hline $5-1$ & $\begin{array}{r}220,300 \\
1,363,600\end{array}$ & $\begin{array}{l}\text { S. Flank } \\
30\end{array}$ & 3.5 & $\begin{array}{l}1.82 \\
\text { med. }\end{array}$ & 1.28 & 0.2 & 7.2 \\
\hline $5-2$ & $\begin{array}{r}216,300 \\
1,360,100\end{array}$ & S. Flank & 17.8 & $\begin{array}{l}2.21 \\
\text { fine }\end{array}$ & 0.69 & -0.6 & $\begin{array}{c}0.2- \\
13.3\end{array}$ \\
\hline $5-4$ & $\begin{array}{r}216,600 \\
1,359,900\end{array}$ & N. Crest & 19.0 & $\begin{array}{l}2.17 \\
\text { fine }\end{array}$ & 0.79 & -1.0 & $\begin{array}{l}0.2- \\
40.4\end{array}$ \\
\hline
\end{tabular}


Table 8

Comparison of Mean Grain Sizes for the Entire Sand Unit and an Upper Layer of Sand in the Cores

\begin{tabular}{|c|c|c|c|}
\hline $\begin{array}{l}\text { Core } \\
\text { No. }\end{array}$ & $\begin{array}{l}\text { Max. Sand Thickness } \\
\text { All/Upper } \\
\end{array}$ & $\begin{array}{c}\text { Mean Grain Size } \\
\text { All/Upper } \\
\end{array}$ & $\begin{array}{l}\text { Wentworth Class } \\
\text { All/Upper }\end{array}$ \\
\hline $4-1$ & $19.3 / 16.2$ & $2.25 / 2.01$ & fine/fine \\
\hline 4-2 & $19.9 / 11.9$ & $2.56 / 2.32$ & fine/fine \\
\hline $4-5$ & $12.6 / 11.4$ & $2.05 / 1.92$ & fine/med. \\
\hline 4-8 & $15.5 / 8.7$ & $2.11 / 1.81$ & fine/med. \\
\hline $5-2$ & $17.8 / 10.3$ & $2.21 / 1.81$ & fine/med. \\
\hline $5-4$ & $19.0 / 9.8$ & $2.17 / 1.66$ & fine/med. \\
\hline
\end{tabular}

is broad with an east-west elongation. This differs from the linear northeast-southwest orientation of most shoals. Only four vibracores (Table 10) and limited geophysical data were collected on this shoal. A bathymetric survey was not conducted. Data from cores show fine sands predominating with intermixed layers of mud. Within sand units, mud varied up to 42 percent. Sand was moderate to poorly sorted and negatively skewed. Cores suggest that up to $20 \mathrm{ft}$ of sand may be available from this shoal. Overall fine grain size may limit its potential as a borrow site, but additional field data would be required to properly determine its value.

85. Borrow site 8 , Borrow site/shoal 8 is located between shoals 5 and 3 (Figure 4). It is small with an indistinct crest and water depths in excess of $40 \mathrm{ft}$. A total of four vibracores (Table 11) and 6 miles of geophysical data were collected over this shoal within the State of Maryland. Cores range from very fine to medium sand, with mud percentages between 1.4 and 25.7. A rough isopach map that was constructed showed sand thickness up to $20 \mathrm{ft}$ at some locations.

86. Borrow site 9 . Borrow site/shoal 9 lies approximately $3 \mathrm{n} . \mathrm{m}$. east of northern Ocean City (Figure 4). It is elongate, trending northeastsouthwest. Three cores (Table 12) and approximately 7 miles of subbottom profiles were collected from this borrow site. Cores indicate at least $19 \mathrm{ft}$ of sand. Sand was medium to fine in grain size, with negative skewness and moderate or better sorting. Samples contained less than 1 -percent mud content. 
Table 9

Summary of Vibracore Analysis for Borrow Site 6

\begin{tabular}{|c|c|c|c|c|c|c|c|}
\hline $\begin{array}{l}\text { Core } \\
\text { No. }\end{array}$ & $\begin{array}{c}\text { Location } \\
\text { State Plane } \\
\mathrm{ft} \\
\end{array}$ & $\begin{array}{l}\text { Descriptive } \\
\text { Location } \\
\text { \& Depth, ft }\end{array}$ & $\begin{array}{l}\text { Max. Sand } \\
\text { Thickness } \\
\mathrm{ft} \\
\end{array}$ & $\begin{array}{l}\text { Mean } \\
\text { Size } \\
\text { phi } \\
\end{array}$ & $\begin{array}{c}\text { Stand. } \\
\text { Dev. } \\
\text { phi } \\
\end{array}$ & $\begin{array}{l}\text { Skew } \\
\text { phi }\end{array}$ & $\begin{array}{c}\text { Mud } \\
8 \\
\end{array}$ \\
\hline 1 & $\begin{array}{r}202,300 \\
1,365,550\end{array}$ & S. Flank & 7.5 & $\begin{array}{l}2.44 \\
\text { fine }\end{array}$ & 0.52 & -1.4 & 0.8 \\
\hline \multirow[t]{2}{*}{2} & $\begin{array}{r}200,500 \\
1,366,400\end{array}$ & S. Trough & 2.0 & $\begin{array}{l}2.89 \\
\text { fine }\end{array}$ & 0.94 & -0.8 & 23.2 \\
\hline & & & 7.2 & $\begin{array}{l}1.89 \\
\text { med. }\end{array}$ & 1.10 & -0.2 & $\begin{array}{l}3.2- \\
12.0\end{array}$ \\
\hline 3 & $\begin{array}{r}195,650 \\
1,359,400\end{array}$ & N. Flank & 16.5 & $\begin{array}{l}1.42 \\
\text { med. }\end{array}$ & 0.60 & -1.2 & $\begin{array}{l}0.0- \\
0.1\end{array}$ \\
\hline \multirow[t]{2}{*}{4} & $\begin{array}{r}198,750 \\
1,361,450\end{array}$ & N. $\begin{array}{l}\text { Flank } \\
31\end{array}$ & 12.1 & $\begin{array}{l}2.11 \\
\text { fine }\end{array}$ & 0.57 & -0.6 & $\begin{array}{l}0.0- \\
0.9\end{array}$ \\
\hline & & & 1.6 & $\begin{array}{l}2.74 \\
\text { fine }\end{array}$ & 0.84 & -0.8 & 9.4 \\
\hline 5 & $\begin{array}{r}197,150 \\
1,363,250\end{array}$ & S. Flank & 16.1 & $\begin{array}{l}2.22 \\
\text { fine }\end{array}$ & 0.65 & -1.4 & $\begin{array}{l}0.9- \\
1.1\end{array}$ \\
\hline 6 & $\begin{array}{r}203,900 \\
1,365,500\end{array}$ & $\begin{array}{l}\text { S. Flank } \\
28\end{array}$ & 15.5 & $\begin{array}{l}2.14 \\
\text { fine }\end{array}$ & 0.55 & -1.4 & 0.1 \\
\hline 7 & $\begin{array}{r}198,500 \\
1,362,550\end{array}$ & N. Flank & 19.7 & $\begin{array}{l}1.77 \\
\text { med. }\end{array}$ & 0.67 & -1.0 & 0.1 \\
\hline
\end{tabular}

87. All borrow site composite grain size analysis and volumetric calculations were performed in a step-wise fashion at 5 -ft vertical intervals or "slices." Each slice represents a horizontal layer of borrow material through the site. The reason for selecting slices for evaluation is based upon the assumption that a dredge will begin operation on the seabed and excavate slices downward incrementally to a prescribed depth. The slices proceeded from the shoal crest downward. Initial slice elevation for a given shoal was based upon crest depth. For example, if crest depth was - $18 \mathrm{ft}$ NGVD, the initial slice would range from -15 to $-20 \mathrm{ft}$ NGVD. Volume of material and composite grain size of this slice were calculated. Successive slices are additive to previous slices to calculate total volume. In this example, a 
Table 10

Summary of Vibracore Analysis for Borrow Site 7

\begin{tabular}{|c|c|c|c|c|c|c|c|}
\hline $\begin{array}{l}\text { Core } \\
\text { No. }\end{array}$ & $\begin{array}{c}\text { Location } \\
\text { State Plane } \\
\mathrm{ft}\end{array}$ & $\begin{array}{l}\text { Descriptive } \\
\text { Location } \\
\text { \& Depth. ft }\end{array}$ & $\begin{array}{c}\text { Max. Sand } \\
\text { Thickness } \\
\mathrm{ft} \\
\end{array}$ & $\begin{array}{l}\text { Mean } \\
\text { Size } \\
\text { phi } \\
\end{array}$ & $\begin{array}{l}\text { Stand. } \\
\text { Dev. } \\
\text { phi }\end{array}$ & $\begin{array}{l}\text { Skew } \\
\text { phi }\end{array}$ & $\begin{array}{c}\text { Mud } \\
8 \\
\end{array}$ \\
\hline \multirow[t]{2}{*}{1} & $\begin{array}{r}186,550 \\
1,360,300\end{array}$ & 43 & 0.5 & $\begin{array}{l}2.46 \\
\text { fine }\end{array}$ & 0.46 & -0.6 & 1.0 \\
\hline & & & 9.5 & $\begin{array}{l}2.09 \\
\text { fine }\end{array}$ & 1.08 & -0.6 & $\begin{array}{r}1.0 \\
10.9\end{array}$ \\
\hline \multirow[t]{2}{*}{2} & $\begin{array}{r}187,550 \\
1,359,750\end{array}$ & 30 & 6.6 & $\begin{array}{l}2.32 \\
\text { fine }\end{array}$ & 0.63 & -1.8 & 1.1 \\
\hline & & & 9.7 & $\begin{array}{l}2.46 \\
\text { fine }\end{array}$ & 0.80 & -0.6 & 13.0 \\
\hline 3 & $\begin{array}{r}190,100 \\
1,361,400\end{array}$ & 40 & 17.1 & $\begin{array}{l}2.33 \\
\text { fine }\end{array}$ & 0.89 & -0.6 & $\begin{array}{r}1.4 \\
42.2\end{array}$ \\
\hline \multirow[t]{3}{*}{4} & $\begin{array}{r}188,550 \\
1,361,800\end{array}$ & 43 & 9.9 & $\begin{array}{l}2.15 \\
\text { fine }\end{array}$ & 1.11 & -1.2 & $\begin{array}{r}1.8 \\
18.7\end{array}$ \\
\hline & & & 1.8 & $\begin{array}{l}1.42 \\
\text { med. }\end{array}$ & 1.13 & -0.8 & 0.8 \\
\hline & & & 2.1 & $\begin{array}{l}1.99 \\
\text { med. }\end{array}$ & 1.16 & -1.2 & 2.3 \\
\hline
\end{tabular}

Table 11

Summary of Vibracore Analysis for Borrow Site 8

\begin{tabular}{|c|c|c|c|c|c|c|c|}
\hline $\begin{array}{l}\text { Core } \\
\text { No. }\end{array}$ & $\begin{array}{c}\text { Location } \\
\text { State Plane } \\
\mathrm{ft} \\
\end{array}$ & $\begin{array}{l}\text { Descriptive } \\
\text { Location } \\
\underline{\text { s Depth, ft }}\end{array}$ & $\begin{array}{c}\text { Max. Sand } \\
\text { Thickness } \\
\text { ft } \\
\end{array}$ & $\begin{array}{l}\text { Mean } \\
\text { Size } \\
\text { phi } \\
\end{array}$ & $\begin{array}{l}\text { Stand. } \\
\text { Dev. } \\
\text { phi }\end{array}$ & $\begin{array}{l}\text { Skew } \\
\text { phi }\end{array}$ & $\begin{array}{c}\text { Mud } \\
8 \\
\end{array}$ \\
\hline 1 & $\begin{array}{r}230,450 \\
1,366,650\end{array}$ & 41 & 18.0 & $\begin{array}{l}1.69 \\
\text { med. }\end{array}$ & 1.14 & -0.2 & $\begin{array}{l}1.4- \\
17.1\end{array}$ \\
\hline 2 & $\begin{array}{r}226,700 \\
1,367,050\end{array}$ & 38 & 18.6 & $\begin{array}{l}1.55 \\
\text { med. }\end{array}$ & 1.20 & 0.0 & $\begin{array}{r}2.0- \\
11.9\end{array}$ \\
\hline 3 & $\begin{array}{r}228,200 \\
1,366,500\end{array}$ & 38 & 11.6 & $\begin{array}{l}3.50 \\
\text { very } \\
\text { fine }\end{array}$ & 0.52 & -0.8 & 25.9 \\
\hline 4 & $\begin{array}{r}226,700 \\
1,367,600\end{array}$ & 45 & 20.0 & $\begin{array}{l}1.66 \\
\text { med. }\end{array}$ & 1.13 & -1.0 & $\begin{array}{l}1.0- \\
20.3\end{array}$ \\
\hline
\end{tabular}


Table 12

Summary of Vibracore Analysis for Borrow Site 9

\begin{tabular}{|c|c|c|c|c|c|c|c|}
\hline $\begin{array}{l}\text { Core } \\
\text { No. }\end{array}$ & $\begin{array}{c}\text { Location } \\
\text { State Plane } \\
\mathrm{ft} \\
\end{array}$ & $\begin{array}{l}\text { Descriptive } \\
\text { Location } \\
\text { \&epth, ft }\end{array}$ & $\begin{array}{c}\text { Max. Sand } \\
\text { Thickness } \\
\text { ft } \\
\end{array}$ & $\begin{array}{l}\text { Mean } \\
\text { Size } \\
\text { phi }\end{array}$ & $\begin{array}{l}\text { Stand. } \\
\text { Dev. } \\
\text { phi }\end{array}$ & $\begin{array}{l}\text { Skew } \\
\text { phi }\end{array}$ & $\begin{array}{c}\text { Mud } \\
8\end{array}$ \\
\hline 1 & $\begin{array}{r}213,250 \\
1,372,500\end{array}$ & 36 & 19.0 & $\begin{array}{l}1.15 \\
\text { med. }\end{array}$ & 0.60 & 0.0 & 0.2 \\
\hline 2 & $\begin{array}{r}221,600 \\
1,376,050\end{array}$ & 27 & 15.7 & $\begin{array}{l}2.18 \\
\text { fine }\end{array}$ & 0.47 & -1.4 & 0.2 \\
\hline 3 & $\begin{array}{r}216,800 \\
1,374,500\end{array}$ & 27 & 13.1 & $\begin{array}{l}1.88 \\
\text { med. }\end{array}$ & 0.44 & -1.2 & 0.1 \\
\hline
\end{tabular}

second slice would include the volume and composite sample between -15 and -25 ft NGVD.

88. Copies of $1: 2,400$-scale hydrographic surveys of shoal crests at each borrow site were annotated to show contours at a 5 -ft interval and maximum limit of dredging (Appendix $\mathrm{C}$ ). The 5 -ft contour interval on hydrographic surveys corresponds to $5 \mathrm{ft}$ slices used to calculate borrow site volumes and composite samples. It was intended to allow shoal dredging to proceed down to surrounding topography. Surrounding elevation was determined from hydrographic surveys and geophysical cross sections. In some instances, requisite depth was beyond the map limit. In those cases, map borders were used as dredging limits. Hydrographic surveys were completed for each primary borrow site by the Wilmington District under direct supervision of NAB and DNR.

89. Digital hydrographic survey data for each primary shoal were entered into the Radian Corporation Contour Plotting System (CPS-1) for volumetric calculations. Volume of material in each borrow slice was calculated within given survey boundaries. Actual borrow site volume probably exceeds calculated volume as CPS-1 could calculate only shoal volume contained within survey boundaries. It is likely borrow material is available beyond the map border. Expansion of hydrographic surveys beyond the immediate site may have proved valuable in completely defining borrow material limits.

90. Composite statistics for each slice were calculated by determining what sediment characteristics were within cores in the region where it was intersected by a slice. Individual sieve weights for core sands within the 
slice region were averaged for each sieve to determine a slice composite sample. Method of moment statistics were calculated for this composite sample. In cases where a core contained two distinct lithologies in a slice, percentage of the whole represented by each lithology was used to calculate the composite. In this way a composite mean grain size and standard deviation were calculated for each slice.

91. In retrospect, this technique might be improved by simultaneously examining aerial distribution of grain sizes. It should not be assumed, as in this technique, that grain sizes within an entire shoal slice are constant. Several cores clustered in one part of a borrow cannot be assumed to be representative of an entire site. An alternative strategy to one used at Ocean City would be to weight each core in a composite calculation based on percentage of total borrow site area it represents, which is a function of its distance from other cores. As will be shown later, sampling at regular intervals in a grid pattern over a borrow site can eliminate this problem.

92. Let us examine a hypothetical example for illustration. Assume a borrow site slice with five cores through it, as shown in Figure 17, and a definable aerial boundary. For this example, assume no vertical variation in sediments in each core throughout the thickness of a slice. Grain size data for each sieve interval in each core are shown in Table 13. In the composite

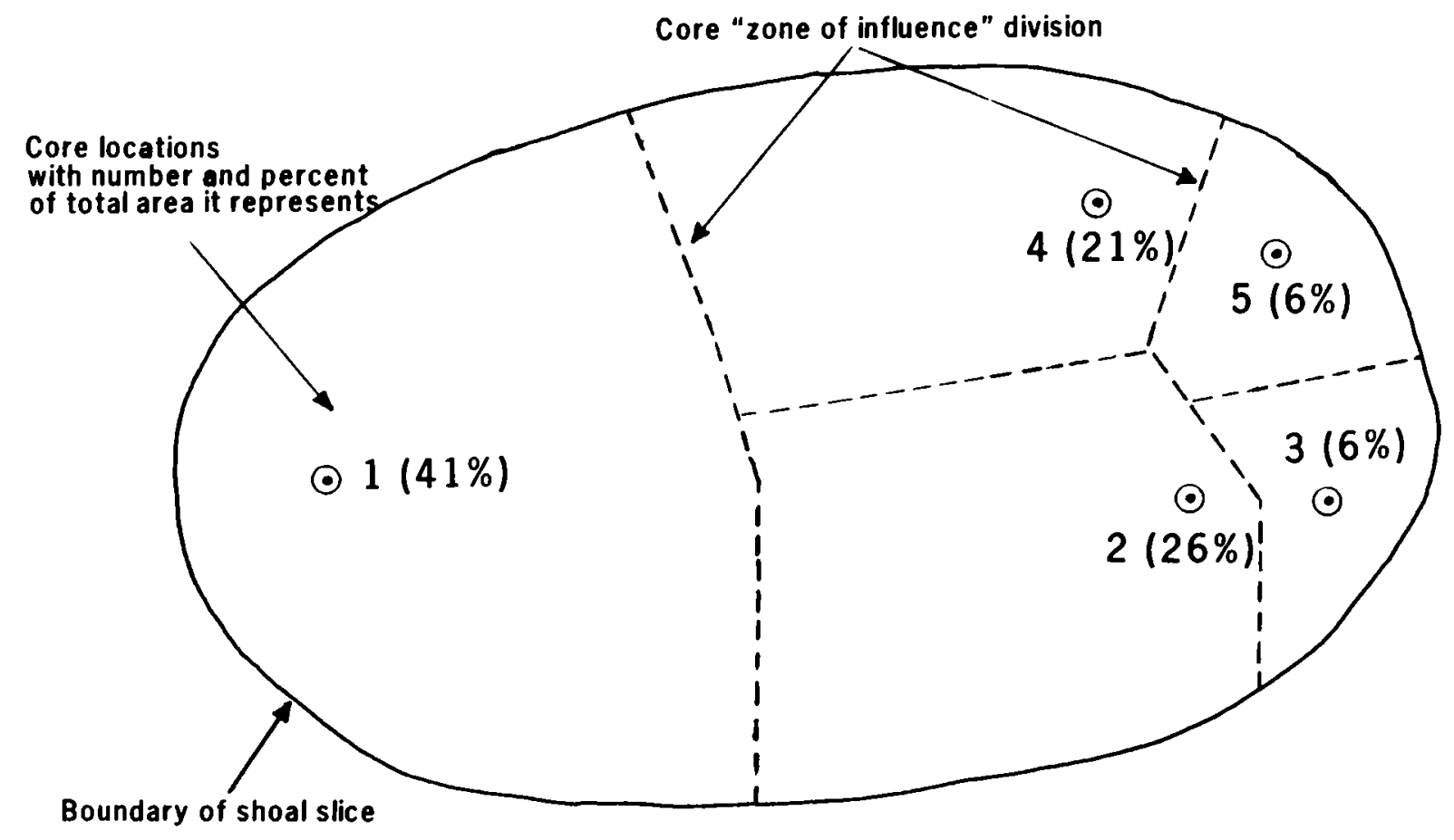

Figure 17. Hypothetical shoal map with irregular core locations 
Table 13

Percent Weight of Sediment Retained on Each Sieve for Five Hypothetical Cores Through a Shoal Slice

\begin{tabular}{|c|c|c|c|c|c|}
\hline $\begin{array}{c}\text { Sieve Size } \\
\text { phi } \\
\end{array}$ & $\begin{array}{c}\text { Core } 1 \\
8 \mathrm{wt} . \\
\end{array}$ & $\begin{array}{l}\text { Core } 2 \\
8 \mathrm{wt} .\end{array}$ & $\begin{array}{l}\text { Core } 3 \\
8 \mathrm{wt} . \\
\end{array}$ & $\begin{array}{c}\text { Core } 4 \\
8 \mathrm{wt} .\end{array}$ & $\begin{array}{l}\text { Core } 5 \\
8 \text { wt. }\end{array}$ \\
\hline-2.00 & 0.00 & 0.00 & 1.43 & 0.00 & 1.63 \\
\hline-1.75 & 0.07 & 0.08 & 0.43 & 0.17 & 1.45 \\
\hline-1.50 & 0.00 & 0.18 & 1.35 & 0.00 & 2.69 \\
\hline-1.25 & 0.05 & 0.00 & 2.96 & 0.08 & 3.06 \\
\hline-1.00 & 0.12 & 0.00 & 3.96 & 0.08 & 2.65 \\
\hline-0.75 & 0.09 & 0.06 & 3.80 & 0.00 & 3.06 \\
\hline-0.50 & 0.07 & 0.08 & 5.84 & 0.07 & 3.90 \\
\hline-0.25 & 0.14 & 0.06 & 7.83 & 0.10 & 4.57 \\
\hline 0.00 & 0.12 & 0.18 & 8.32 & 0.20 & 4.33 \\
\hline 0.25 & 0.30 & 0.34 & 14.42 & 0.37 & 8.28 \\
\hline 0.50 & 0.41 & 0.48 & 11.95 & 0.37 & 7.63 \\
\hline 0.75 & 0.75 & 0.80 & 12.14 & 0.57 & 9.26 \\
\hline 1.00 & 2.14 & 2.03 & 11.08 & 1.33 & 14.19 \\
\hline 1.25 & 3.07 & 2.63 & 3.98 & 1.70 & 5.86 \\
\hline 1.50 & 3.23 & 3.15 & 1.43 & 1.36 & 5.10 \\
\hline 1.75 & 7.03 & 7.68 & 1.39 & 2.67 & 4.35 \\
\hline 2.00 & 14.73 & 17.31 & 1.16 & 6.28 & 4.06 \\
\hline 2.25 & 16.28 & 19.64 & 1.16 & 11.49 & 4.22 \\
\hline 2.50 & 24.96 & 22.30 & 1.80 & 32.35 & 5.55 \\
\hline 2.75 & 15.67 & 15.71 & 1.96 & 25.46 & 2.71 \\
\hline 3.00 & 7.34 & 5.58 & 0.98 & 11.14 & 1.00 \\
\hline 3.25 & 1.77 & 1.14 & 0.22 & 2.44 & 0.29 \\
\hline 3.50 & 0.64 & 0.28 & 0.10 & 0.74 & 0.06 \\
\hline 3.75 & 0.34 & 0.22 & 0.08 & 0.39 & 0.06 \\
\hline 4.00 & 0.18 & 0.07 & 0.04 & 0.23 & 0.03 \\
\hline$<4.00$ & 0.50 & 0.00 & 0.19 & 0.41 & 0.01 \\
\hline
\end{tabular}


calculation scheme used at Ocean City, sediment data from each core within a slice would be averaged equally to form a composite (Table 14). Composite mean of this slice would be $1.50 \mathrm{phi}$, and standard deviation would be 1.21. An alternative approach is to divide the slice area into subsections based on median distance between cores (dotted lines, Figure 17). This would simply involve constructing division lines that were always equidistant between adjacent cores. Entire slice area and each subsection could be measured, and percentage of the whole each subsection represented could be calculated. That percentage could be applied to sieve weights when calculating a composite sample of the slice (Table 14). In this case, weighting each sieve weight in accordance to percentage of total area it represented, the composite mean grain size is $1.98 \mathrm{phi}$, and standard deviation is 0.89 (Table 14).

93. Assuming a native beach of mean grain size 1.84 phi with a standard deviation of 1.22 , we can calculate an overfill ratio required for borrow site sediment using the two different borrow site compositing schemes. Overfill ratios were calculated following procedures outlined in the SPM (1984). In the first case, where aerial distribution of cores was not considered, overfill ratio was approximately 1.01 . This suggests sand throughout the slice is approximately the same as the native beach. In the second case, where clustering and scattering of cores were considered in calculation of a composite sample, the overfill ratio is approximately 1.75. Assuming this approach is better scientifically, it suggests much more sand is actually required to fill the beach than could be predicted by the first method.

94. Figure 18 shows an aerial view of a shoal slice in which cores are approximately evenly spaced. Using data in Table 13, a weighted composite sample can be calculated (Table 14). The result is a composite mean grain size of 1.53 phi and a 1.19 standard deviation. This is not significantly different from the example of the technique used at Ocean City (mean $=1.50$, standard deviation $=1.21$; Table 14), where samples were evenly spaced over the shoal, but composite weighting was not used. Overfill ratios are similar in both cases. This points out that an initial even-spaced borrow site sampling pattern will not require weighted compositing later.

95. Spatial distribution of sediment in a borrow site may be examined in a more qualitative way by constructing grain size distribution maps. Similar to the way in which one might use elevation data to construct a topographic map, grain size data from cores could be used to develop grain size 
Table 14

Composite Samples Calculated from Core Data

\begin{tabular}{|c|c|c|c|}
\hline $\begin{array}{c}\text { Sieve Size } \\
\text { phi }\end{array}$ & $\begin{array}{l}\text { Composite Without } \\
\text { Aerial Weighting } \\
\text { of Core Locations } \\
\text { weight percent } \\
\end{array}$ & $\begin{array}{l}\text { Composite With } \\
\text { Weighting of } \\
\text { Irregularly } \\
\text { Placed Cores } \\
\end{array}$ & $\begin{array}{c}\text { Composite With } \\
\text { Weighting of } \\
\text { Regularly } \\
\text { Placed Cores } \\
\end{array}$ \\
\hline-2.00 & 0.61 & 0.18 & 0.57 \\
\hline-1.75 & 0.44 & 0.20 & 0.40 \\
\hline-1.50 & 0.84 & 0.29 & 0.78 \\
\hline-1.25 & 1.23 & 0.40 & 1.14 \\
\hline-1.00 & 1.36 & 0.46 & 1.27 \\
\hline-0.75 & 1.40 & 0.46 & 1.31 \\
\hline-0.50 & 1.99 & 0.65 & 1.86 \\
\hline-0.25 & 2.54 & 0.84 & 2.37 \\
\hline 0.00 & 2.63 & 0.90 & 2.46 \\
\hline 0.25 & 4.74 & 1.65 & 4.43 \\
\hline 0.50 & 4.17 & 1.55 & 3.91 \\
\hline 0.75 & 4.70 & 1.92 & 4.42 \\
\hline 1.00 & 6.15 & 3.20 & 5.85 \\
\hline 1.25 & 3.45 & 2.89 & 3.43 \\
\hline 1.50 & 2.85 & 2.82 & 2.91 \\
\hline 1.75 & 4.62 & 5.78 & 4.93 \\
\hline 2.00 & 8.71 & 12.17 & 9.44 \\
\hline 2.25 & 10.56 & 14.52 & 11.11 \\
\hline 2.50 & 17.39 & 23.27 & 17.29 \\
\hline 2.75 & 12.30 & 16.14 & 11.95 \\
\hline 3.00 & 5.21 & 6.92 & 5.08 \\
\hline 3.25 & 1.17 & 1.57 & 1.15 \\
\hline 3.50 & 0.36 & 0.50 & 0.37 \\
\hline 3.75 & 0.22 & 0.29 & 0.22 \\
\hline 4.00 & 0.11 & 0.14 & 0.11 \\
\hline$<4.00$ & 0.22 & 0.30 & 0.23 \\
\hline Mean & 1.50 (phi) & 1.98 (phi) & 1.53 (phi) \\
\hline Standard Dev. & 1.21 & 0.89 & 1.19 \\
\hline
\end{tabular}




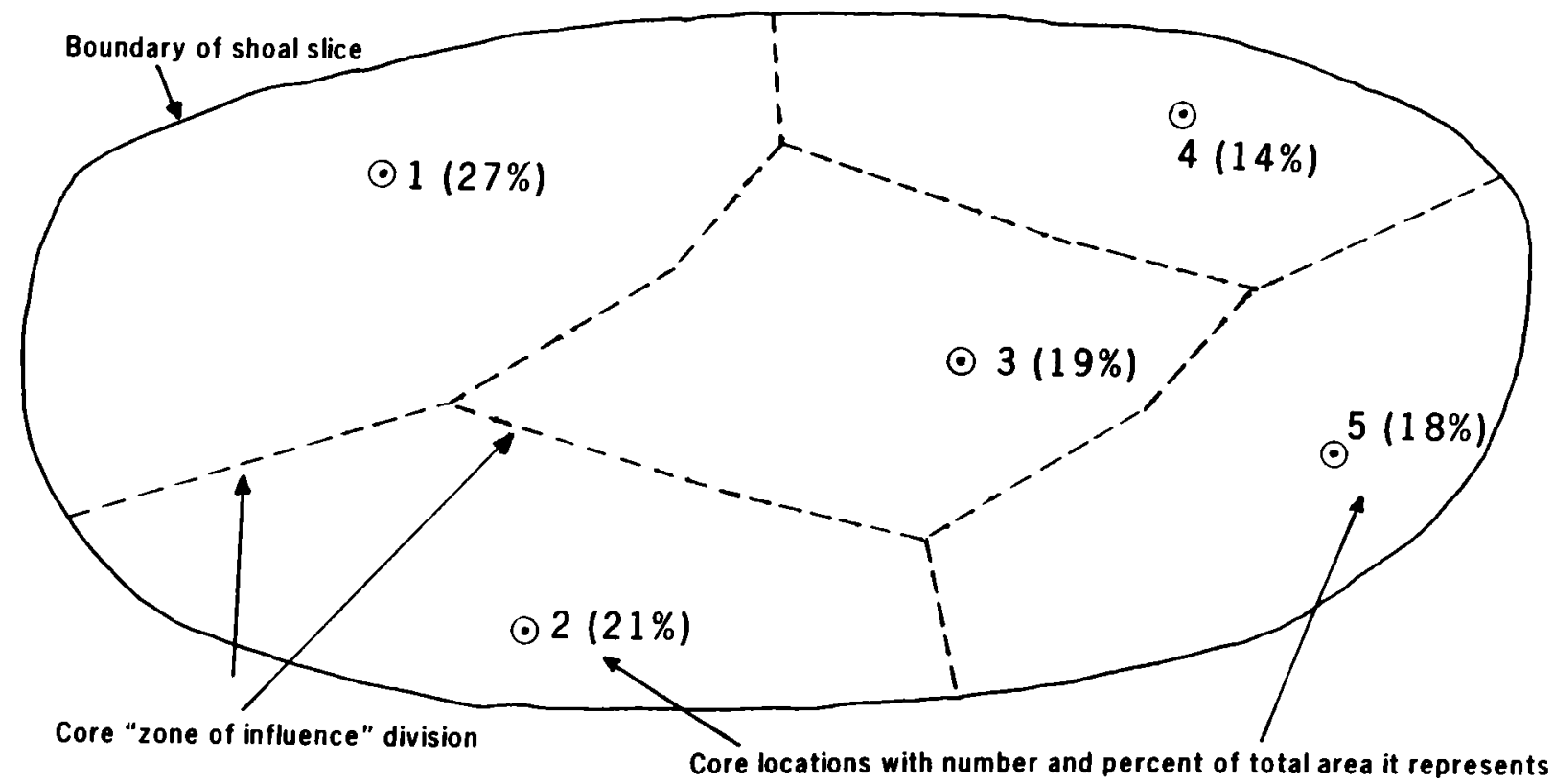

Figure 18. Hypothetical shoal map with evenly spaced core locations maps for each borrow site slice. Overlaying these maps would give a good three-dimensional indication of where best grain sizes for nourishment are located in a borrow site. Combined with isopach maps showing sediment thickness, volumes of specific areas of borrow sites could be calculated and targeted for dredging. These areas could be clearly marked on maps for dredging contractors. This approach was originally examined for Ocean City, but was dismissed for a variety of reasons. 
96. With completion of analysis of beach and borrow site data, a final task was to determine how much sand to dredge and place on the beach at Ocean City. Several steps were required to complete this task. Given a planned final beach design and a set of recent profile surveys, the volume of native beach sand required to fill the design profile had to be calculated. Sediment data from the beach and borrow sites were used to calculate overfill and renourishment factors, which together with volume data, could be used to evaluate the usefulness of particular borrow sites. The volume of sediment in each usable slice of each borrow site had to be determined. Overfill ratios were then applied to determine amounts of sediment to be dredged and placed.

\section{Determination of Required Fill Volumes}

97. Figure 19 illustrates methodology used to construct design templates and calculate beach-fill volumes at each profile location. In this

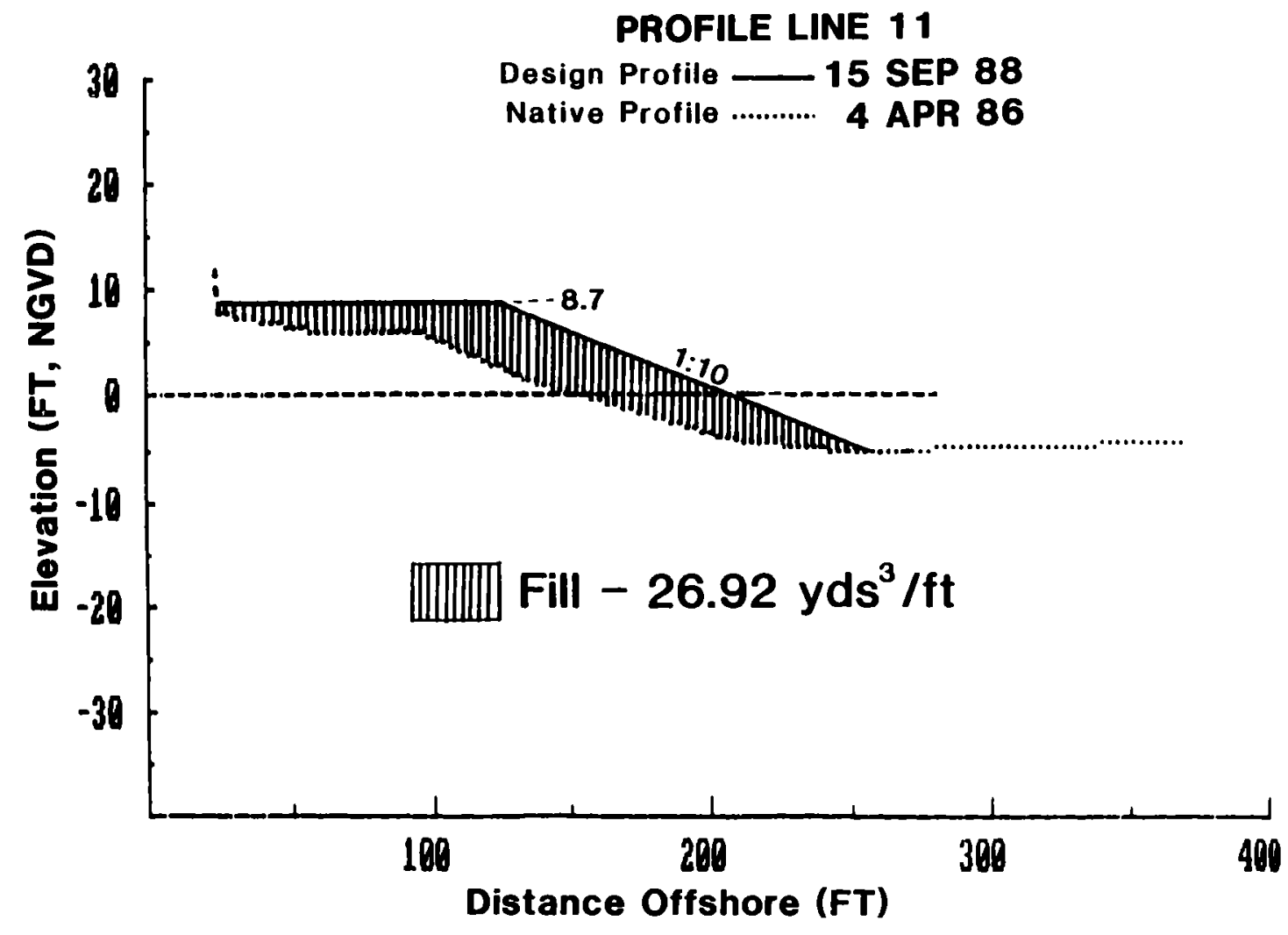

Figure 19. Design template for profile line 11 
example, a 100 -ft berm platform was drawn seaward from natural profiles at an elevation of $8.7 \mathrm{ft}$ NGVD. An artificial beach face was drawn seaward of the berm platform with a $1: 10$ slope. Intersection with the natural profile occurred at depths of about -3 to $-4 \mathrm{ft}$ NGVD (Figure 19). The Interactive Survey Reduction Program (Birkemeier 1984) was used to calculate area of fill, with sediment compatible with the native beach, required to meet design specifications at profile locations. Volumes were measured as cubic yards per foot of beach.

98. Fill volumes at each profile location were considered to represent reaches of beach with borders extending half the distance to adjacent profile stations. Beach-fill volumes necessary to construct design profiles within each cell were calculated by multiplying profile fill volumes by the width of each cell. In Figure 19, the cell represented by profile 11 would require $26.92 \mathrm{yd}^{3} / \mathrm{ft}$ of native beach sediment along $1,227.5 \mathrm{ft}$ of beach, for a cell volume of $47,580 \mathrm{yd}^{3}$. The sum of all cell volumes within the project represents total volume of fill material necessary for completion.

99. The DNR requested CERC to provide three design scenarios. Scenario one would construct a 100 -ft-wide berm from the construction setback line, at an elevation of $6.0 \mathrm{ft}$ NGVD (7.5 ft MLW), then sloping at $1: 10$ to intersect the existing profile (Figure 20). This scenario would require approximately $600,000 \mathrm{yd}^{3}$ of fill material identical in sediment characteristics to the native beach. Scenario two would construct a 100 -ft-wide berm from the construction setback line, at an elevation of $8.5 \mathrm{ft}$ NGVD, then sloping at 1:10 to intersect the existing profile (Figure 21). Approximately 1,100,000 $\mathrm{yd}^{3}$ of stable material would be required to construct this design. For scenario three, CERC was requested to provide a design that would have a 100 -ft-wide berm from the construction setback line, at an elevation of $8.5 \mathrm{ft}$ NGVD. Foreshore slope would be designed so the entire 8 miles of beach would have $1,400,000 \mathrm{yd}^{3}$ of material distributed in such a manner as to provide a nearly uniform beach width (Figure 22). Analysis of 31 profile lines collected in April 1986 indicated a 1:12 foreshore slope to existing bottom would provide for the required volume.

100. Of the three design scenarios, the third design was chosen by DNR for implementation. This design will provide at the moment of placement an average constructed beach condition of a 100 -ft-wide berm at elevation $8.5 \mathrm{ft}$ NGVD, sloping to existing bottom with a 1 -ft vertical change for every $12 \mathrm{ft}$ 


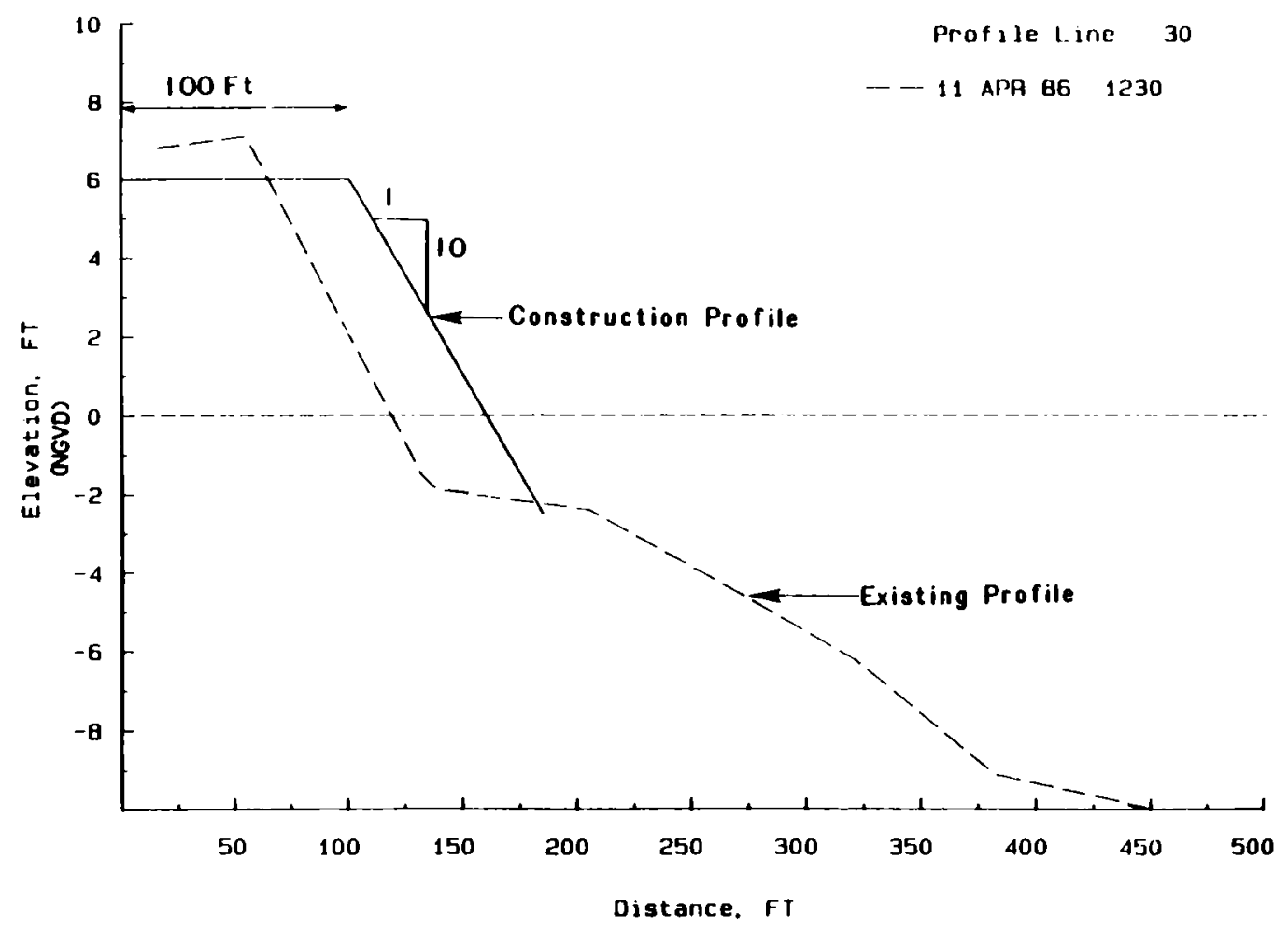

Figure 20. Design template scenario 1

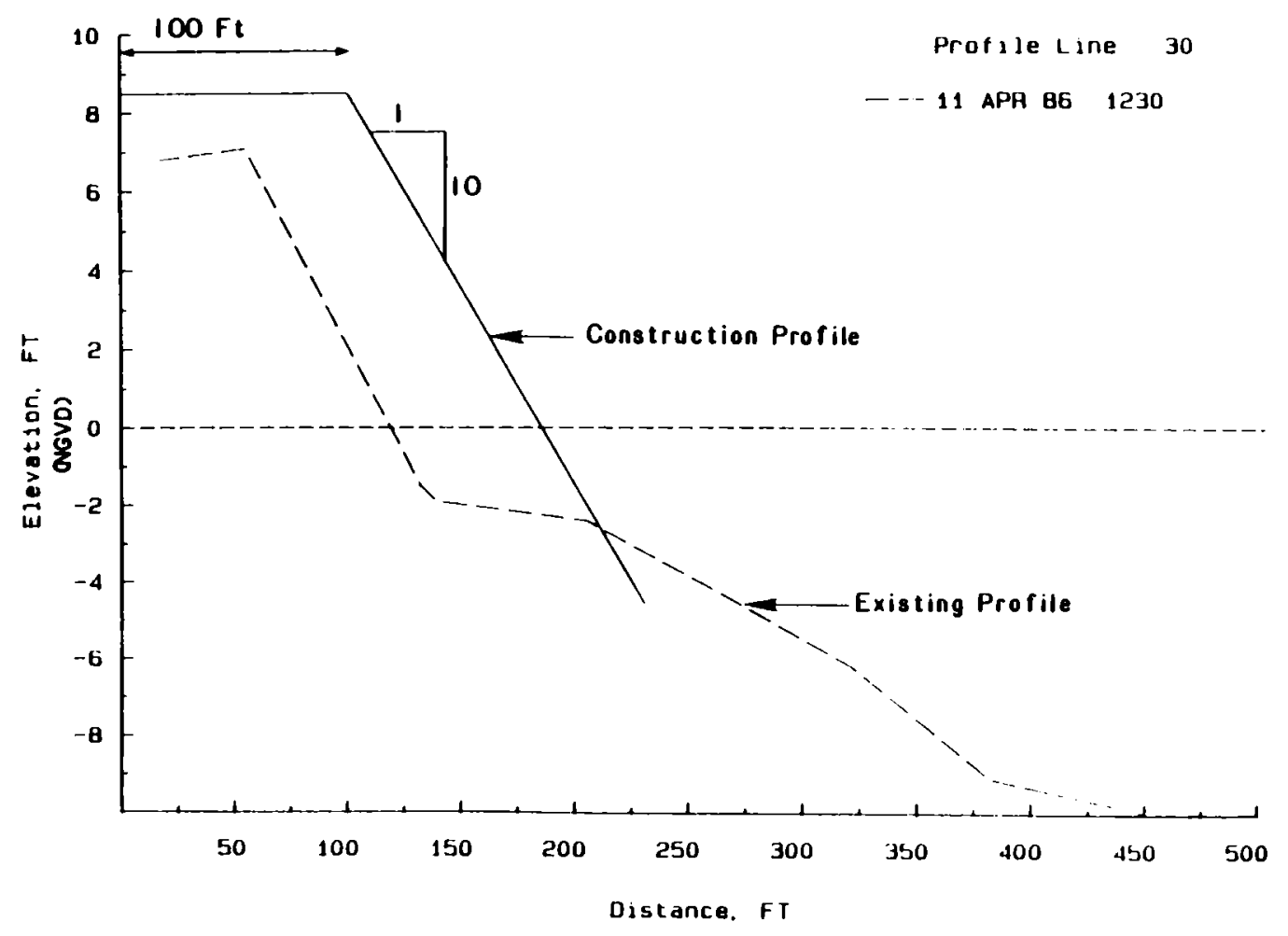

Figure 21. Design template scenario 2 


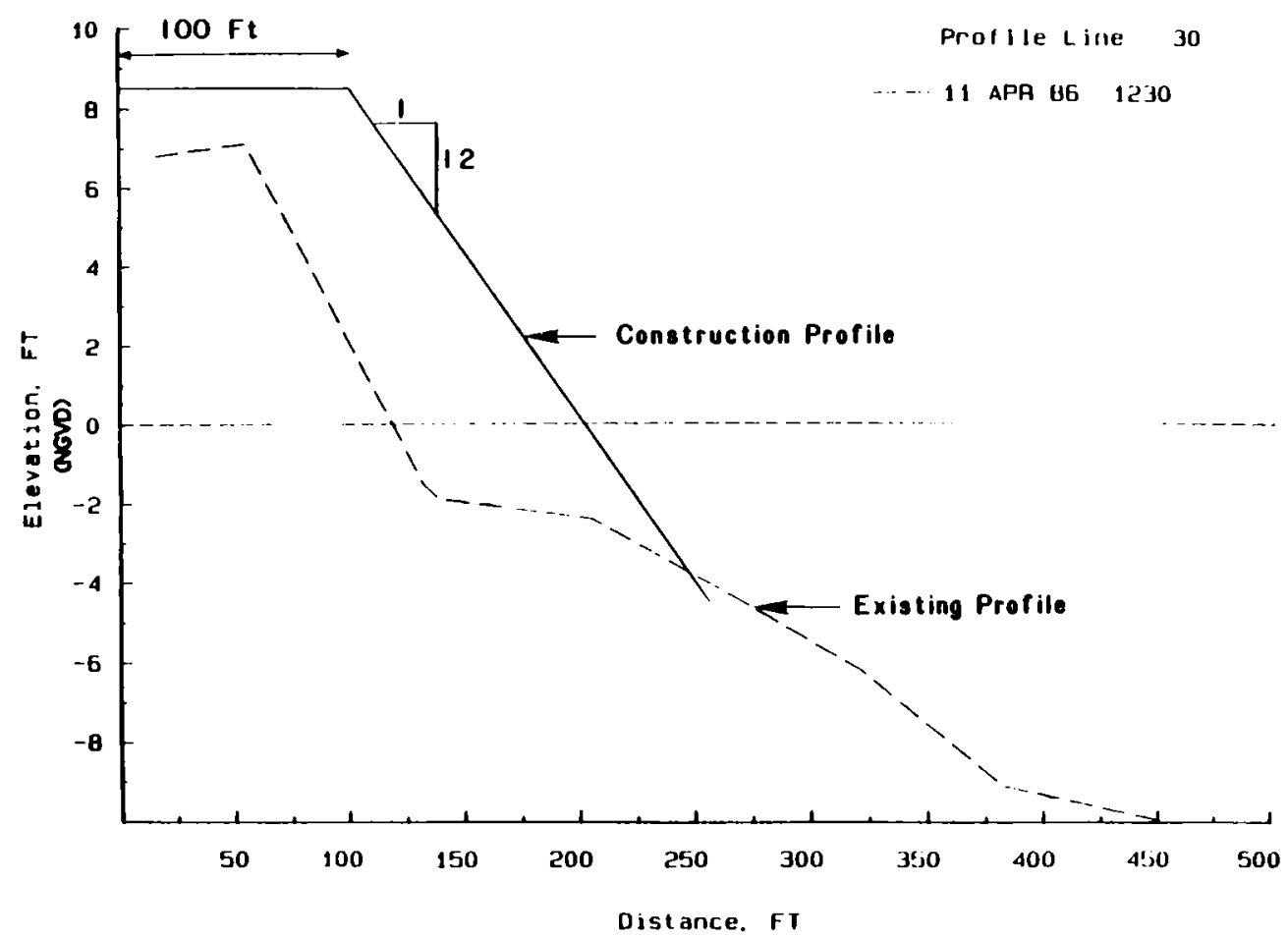

Figure 22. Design template scenario 3

of horizontal change. This is actually a theoretical design as wave action will naturally adjust the fill, probably causing initial shoreline scarping.

101. Table 15 shows volume required for profiles 6 through 37 for scenario three. Volume per profile $\left(\mathrm{yd}^{3} / \mathrm{ft}\right.$ of beach) was determined using procedures discussed in the example above. Total volume for 8 miles of beach is approximately $1,370,000 \mathrm{yd}^{3}$, or $33 \mathrm{yd}^{3} / \mathrm{ft}$ of beach.

102. During the course of study, discussion arose over whether DNR wanted a beach that had 1.4 million $\mathrm{yd}^{3}$ of sand placed on it initially or a beach that had 1.4 million $\mathrm{yd}^{3}$ on it after adjustment of fill to an equilibrium profile shape. Results of this discussion brought up interesting points which suggest possible new directions for beach fill design. If $1.4 \mathrm{mil}$ lion $\mathrm{yd}^{3}$ of sand are placed on the beach, the final subaerial beach immediately after construction would be approximately $165 \mathrm{ft}$ wide to MLW. However, since fill material is not identical to the native beach and since the native beach does not have a $1: 12$ slope, readjustment will begin immediately. The cross-section profile will attempt to return to a equilibrium shape similar to prefill profiles, only displaced seaward. During that process waves will sort fine material offshore. Very fine silts and clays will be lost completely 
Table 15

Volume Required Per Profile and Cell Volume, Scenario 3

\begin{tabular}{|c|c|c|c|c|}
\hline $\begin{array}{l}\text { Profile } \\
\text { No. } \\
\end{array}$ & $\begin{array}{l}\text { Volume/ft } \\
\text { of Beach } \\
\mathrm{yd}^{3} \\
\end{array}$ & $\begin{array}{l}\text { Distance } \\
\text { Between } \\
\text { Profiles }\end{array}$ & $\begin{array}{l}\text { Cell width } \\
\mathrm{ft}\end{array}$ & $\begin{array}{c}\text { Cell Volume } \\
\mathrm{yd}^{3} \\
\end{array}$ \\
\hline 6 & 27.96 & 10020 & $1,024.5$ & $28,645.0$ \\
\hline 7 & 40.07 & 699.0 & 850.5 & $34,079.5$ \\
\hline 8 & 48.09 & $1,754.0$ & $1,226.5$ & $58,982.4$ \\
\hline 9 & 50.59 & $1,750.0$ & $1,750.0$ & $56,385.3$ \\
\hline 10 & 46.01 & 701.0 & $1,225.5$ & $56,385.3$ \\
\hline 11 & 41.80 & $1,751.0$ & $1,226.0$ & $51,246.8$ \\
\hline 13 & 6.33 & $1,589.0$ & $1,670.0$ & $43,971.1$ \\
\hline 14 & 7.96 & $1,199.0$ & $1,394.0$ & $25,036.2$ \\
\hline 15 & 7.58 & $1,202.0$ & $1,200.5$ & $21,104.8$ \\
\hline 16 & 0.82 & 899.0 & $1,050.5$ & $21,871.4$ \\
\hline 17 & 22.74 & $1,232.0$ & $1,065.5$ & $24,229.5$ \\
\hline 18 & 37.25 & $1,200.0$ & $1,216.0$ & $45,296.0$ \\
\hline 19 & 11.99 & $1,501.0$ & $1,350.5$ & $16,192.5$ \\
\hline 20 & 10.00 & $1,504.0$ & $1,502.5$ & $15,025.0$ \\
\hline 21 & 23.97 & $1,502.0$ & $1,503.0$ & $36,026.9$ \\
\hline 22 & 41.36 & $1,500.0$ & $1,501.0$ & $62,081.4$ \\
\hline 23 & 65.36 & $1,500.0$ & $1,500.0$ & $98,040.0$ \\
\hline 24 & 49.08 & $1,401.0$ & $1,450.5$ & $71,190.5$ \\
\hline 25 & 56.98 & $1,597.0$ & $1,499.0$ & $85,413.0$ \\
\hline 26 & 27.37 & $1,086.0$ & $1,341.5$ & $36,716.9$ \\
\hline 27 & 24.43 & $1,436.0$ & $1,261.0$ & $30,806.2$ \\
\hline
\end{tabular}

(Continued) 
Table 15 (Concluded)

\begin{tabular}{|c|c|c|c|c|}
\hline $\begin{array}{l}\text { Profile } \\
\text { No. } \\
\end{array}$ & $\begin{array}{l}\text { Volume/ft } \\
\text { of Beach } \\
\mathrm{yd}^{3} \\
\end{array}$ & $\begin{array}{l}\text { Distance } \\
\text { Between } \\
\text { Profiles }\end{array}$ & $\begin{array}{l}\text { Cell Width } \\
\frac{\mathrm{ft}}{}\end{array}$ & $\begin{array}{c}\text { Cell Volume } \\
\mathrm{yd}^{3} \\
\end{array}$ \\
\hline 28 & 24.93 & 1.465 .0 & $1,450.5$ & $36,161.0$ \\
\hline 29 & 22.72 & $1,019.0$ & $1,242.0$ & $28,218.2$ \\
\hline 30 & 32.07 & $1,373.0$ & $1,196.0$ & $38,355.7$ \\
\hline 31 & 33.23 & $1,474.0$ & $1,423.5$ & $47,302.9$ \\
\hline 32 & 25.63 & $1,850.0$ & $1,662.0$ & $42,597.1$ \\
\hline 33 & 21.97 & $1,851.0$ & $1,850.5$ & $40,655.5$ \\
\hline 34 & 26.21 & $1,426.0$ & $1,638.5$ & $42,945.1$ \\
\hline 35 & 25.77 & $1,496.0$ & $1,461.0$ & $37,650.0$ \\
\hline 36 & 24.37 & $1,450.0$ & $1,473.0$ & $35,897.0$ \\
\hline 37 & 47.72 & & 1.450 .0 & 69.194 .0 \\
\hline & & Total $=$ & $42,657.5$ & $1,369,950.5$ \\
\hline
\end{tabular}


from the placement area, and fine sands may move as far offshore as closure depth. The final result will be an increase in volume along the entire profile length out to closure. Since volume of fill is fixed, this will mean a reduction of fill on the subaerial beach and therefore less than $165 \mathrm{ft}$ of beach. The final beach width will depend on how much fill is moved offshore to fill the profile, and how much is moved out of the project placement area. Longshore movement of sediment can play a major role in the lifespan of a project. Not accounting for fill redistribution across the entire active profile has been typical of projects in the past. It requires frequent periodic maintenance to keep a desired subaerial width as the entire profile readjusts.

103. An alternative procedure would be to place enough fill on a beach initially so that after adjustment to an equilibrium profile, the beach was at its desired width. Volume of sediment required for this could be calculated by assuming that the present profile approximates equilibrium. The natural profile shape would be extended seaward the desired distance, and area/volume differences between the two profiles would be calculated (Figure 23). Volume of initial sediment required at Ocean City would be much larger $(2,900,000$ versus $1,400,000 \mathrm{yd}^{3}$ ) but periodic nourishment would be minimal. Placement of $2,900,000 \mathrm{yd}^{3}$ would still occur on the subaerial beach; beach width after initial placement would greatly exceed $165 \mathrm{ft}$, but readjustment of $\mathrm{fill}$ by waves into the subaqueous beach would produce an equilibrium profile with the requisite subaerial width. Henceforth, normal beach erosion rates would resume. This procedure is more costly initially; however, since periodic maintenance would be minimal, long-term project cost would be reduced.

\section{Calculation of Overfill Factors}

104. Overfill factors (ratios) were calculated using composite mean grain size and standard deviation of the native beach compared with composite mean grain size and standard deviation for each slice of each potential borrow site. An overfill factor is a term describing how much borrow material is required to produce fill with characteristics similar to native beach material. If borrow material and the native beach have similar sediment, then the overfill ratio is 1 . However, often borrow sites contain material finer than the native beach. Fines will be winnowed out by waves leaving behind a fill 


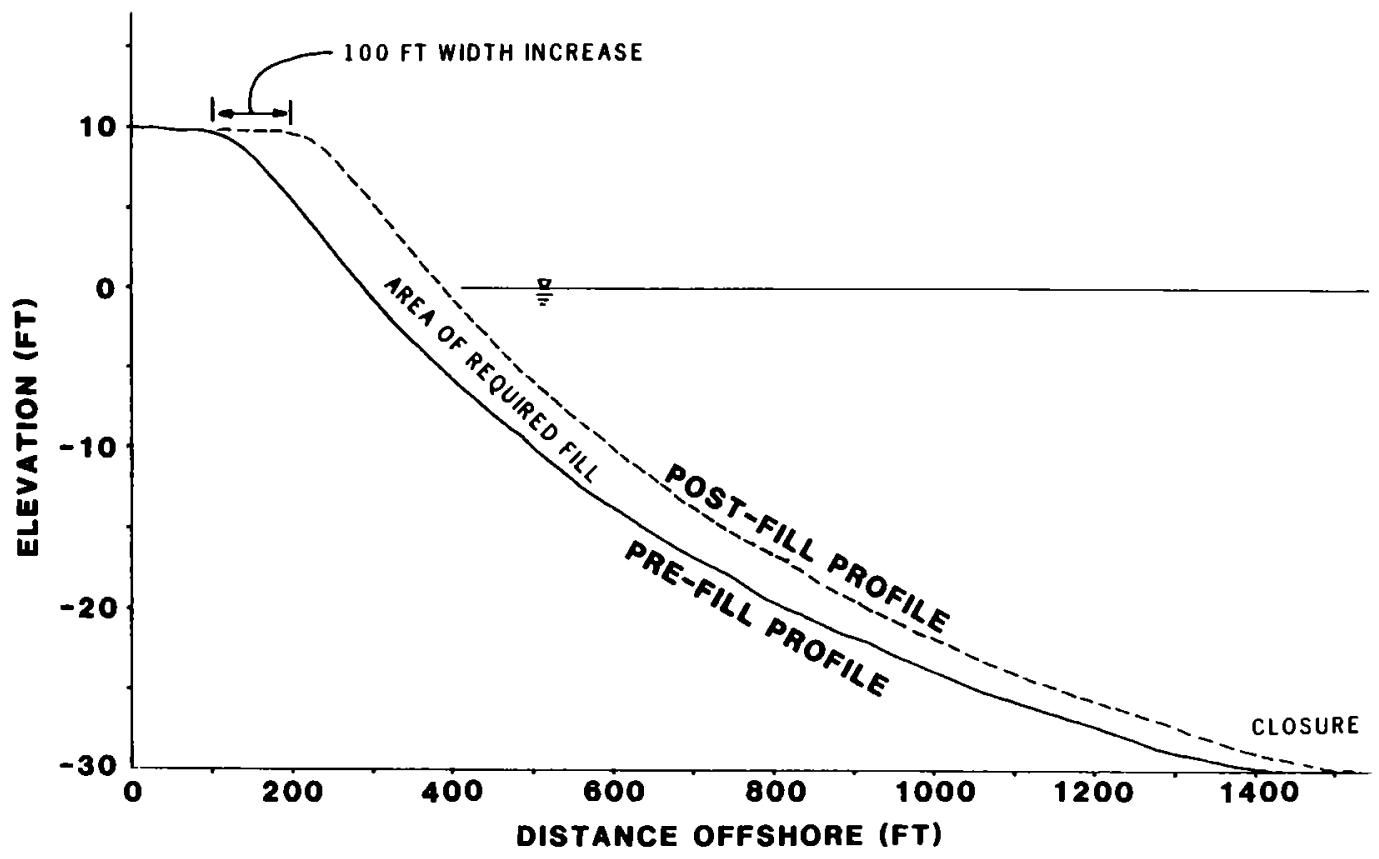

Figure 23. Translation of equilibrium profile seaward to calculate fill volume necessary to nourish the entire profile

that is similar to the native beach. However, to end up with the required beach, more initial fill is necessary. As fines increase and/or as sediment variation decreases in a borrow site overfill, ratios increase. An overfill ratio of 2.0 would mean for every $\mathrm{yd}^{3}$ of native beach sand needed to fill a beach, that amount from the borrow site would need to be doubled. Details of the calculation are presented in the SPM (1984).

105. Mean grain size, standard deviation, and overfill ratios for each slice of each borrow site are presented in Table 16. The last column shows the required volume of sediment from this slice to fill the beach given the overfill factor. From this analysis, relative usefulness of borrow areas becomes apparent. When compared with the native beach, borrow areas 1 and 3 have computed overfill ratios near unity and thus require the least amount of sand $\left(1,400,000 \mathrm{yd}^{3}\right)$ to be dredged. Sites 2 and 4 are next with overfill ratios slightly above 1 . Overfill ratios calculated using sites 5, 6, 7, and 9 are generally too high to make these sites economically viable. Although mean grain sizes on shoals 6 and 9 were similar to the native beach, the range of sediment distribution was limited, therefore requiring more sand to get properly sized fill material. Shoal 8 had good sediment at depth; however, too much nonsuitable overlying sediment would have to be removed to get it. 
Table 16

Examination of Borrow Site Sediments by Slice

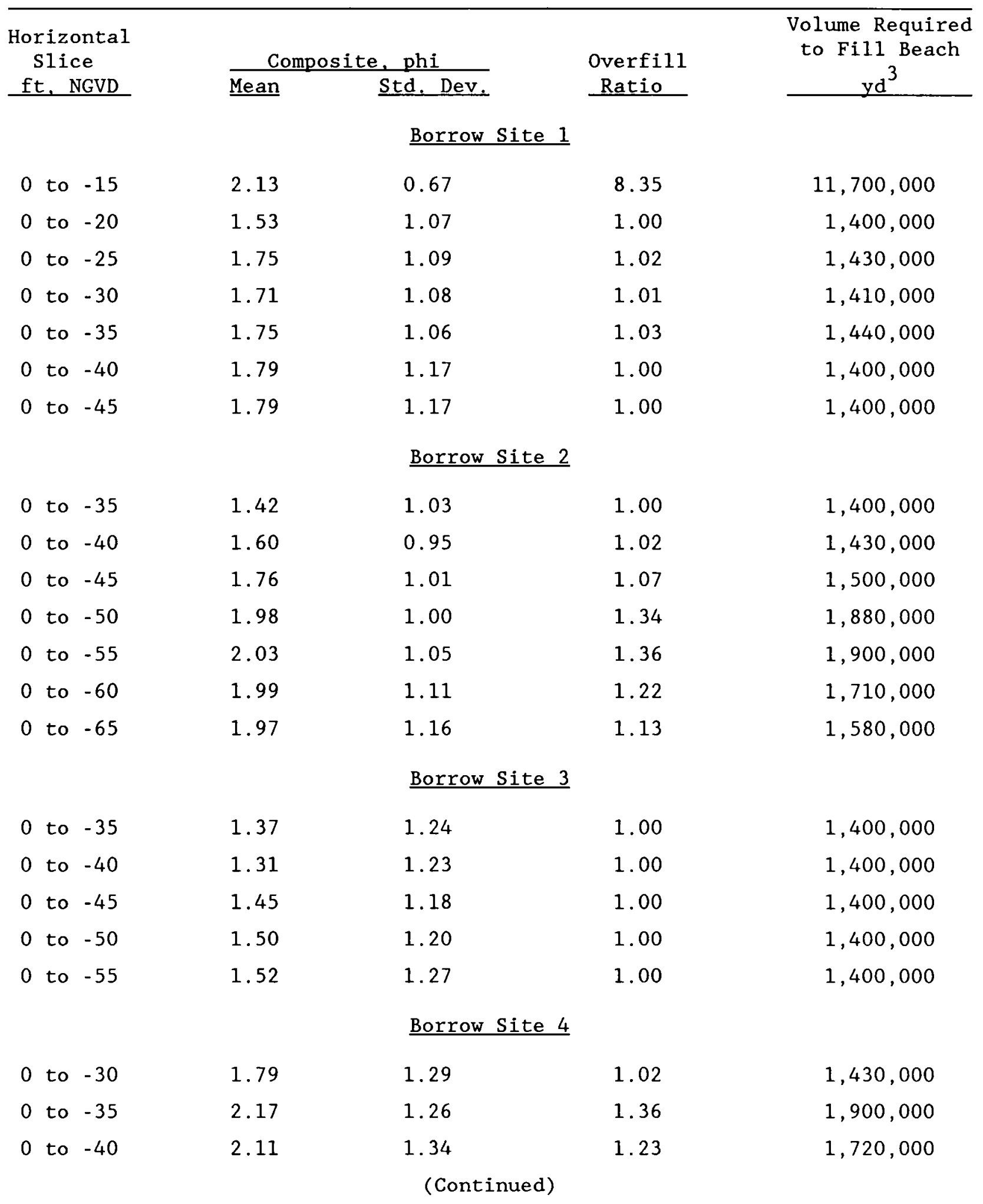


Table 16 (Continued)

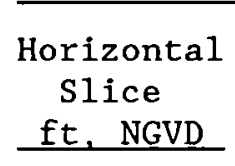

\begin{tabular}{cc} 
Composite,phi & $\begin{array}{l}\text { Overfill } \\
\text { Ratio }\end{array}$ \\
\hline Mean & Std. Dev.
\end{tabular}

Volume Required to Fill Beach

Borrow Site 4 (Continued)

$\begin{array}{lllll}0 \text { to }-45 & 2.13 & 1.28 & 1.29 & 1,810,000 \\ 0 \text { to }-50 & 2.05 & 1.38 & 1.17 & 1,640,000 \\ 0 \text { to }-55 & 2.07 & 1.38 & 1.18 & 1,650,000 \\ 0 \text { to }-60 & 2.10 & 1.39 & 1.21 & 1,690,000\end{array}$

Borrow Site 5

$\begin{array}{lllll}0 \text { to }-30 & 1.59 & 0.88 & 1.06 & 1,480,000 \\ 0 \text { to }-35 & 2.19 & 1.05 & 1.70 & 2,380,000 \\ 0 \text { to }-40 & 2.39 & 1.10 & 2.15 & 3,010,000 \\ 0 \text { to }-45 & 2.40 & 1.10 & 2.15 & 3,010,000\end{array}$

Borrow Site 6

$\begin{array}{lllll}0 \text { to }-30 & 1.87 & 0.81 & 1.50 & 2,100,000 \\ 0 \text { to }-35 & 1.86 & 0.78 & 1.67 & 2,340,000 \\ 0 \text { to }-40 & 1.86 & 0.82 & 1.51 & 2,110,000 \\ 0 \text { to }-45 & 1.85 & 0.86 & 1.37 & 1,920,000 \\ 0 \text { to }-50 & 1.89 & 0.88 & 1.40 & 1,960,000\end{array}$

Borrow Site 7

$\begin{array}{rrrrr}0 \text { to }-35 & 2.32 & 0.63 & 9.00 & 12,600,000 \\ 0 \text { to }-40 & 2.39 & .72 & .00 & 2,600,000 \\ 0 \text { to }-45 & 2.49 & 0.92 & 4.75 & 6,650,000 \\ 0 \text { to }-50 & 2.35 & 1.06 & 2.20 & 3,080,000 \\ 0 \text { to }-55 & 2.31 & 0.99 & 2.32 & 3,250,000 \\ & & \text { Borrow Site } 8 & & 3,440,000 \\ 0 \text { to }-35 & 1.89 & 0.69 & 2.46 & 2,310,000\end{array}$

(Continued) 
Table 16 (Concluded)

\begin{tabular}{|c|c|c|c|c|}
\hline \multirow{2}{*}{$\begin{array}{l}\text { Horizontal } \\
\text { Slice } \\
\text { ft. NGVD } \\
\end{array}$} & \multicolumn{2}{|c|}{ Composite, phi } & \multirow{2}{*}{$\begin{array}{l}\text { Overfill } \\
\text { Ratio } \\
\end{array}$} & \multirow{2}{*}{$\begin{array}{l}\text { Volume Require } \\
\text { to Fill Beach } \\
\mathrm{yd}^{3} \\
\end{array}$} \\
\hline & Mean & Std. Dev. & & \\
\hline \multicolumn{5}{|c|}{ Borrow Site 8 (Continued) } \\
\hline 0 to -45 & 1.83 & 1.21 & 1.00 & $1,400,000$ \\
\hline 0 to -50 & 1.68 & 1.54 & 1.07 & $1,500,000$ \\
\hline 0 to -55 & 1.64 & 1.57 & 1.08 & $1,510,000$ \\
\hline \multicolumn{5}{|c|}{ Borrow Site 9} \\
\hline 0 to -30 & 2.03 & 0.48 & 9.00 & $12,600,000$ \\
\hline 0 to -35 & 2.03 & .48 & .00 & $2,600,000$ \\
\hline 0 to -40 & 1.73 & 0.67 & 1.80 & $2,520,000$ \\
\hline 0 to -45 & 1.73 & 0.67 & 1.80 & $2,520,000$ \\
\hline 0 to -50 & 1.73 & 0.67 & 1.80 & $2,520,000$ \\
\hline 0 to -55 & 1.73 & 0.67 & 1.80 & $2,520,000$ \\
\hline
\end{tabular}


As a result of this analysis, sites 5 through 9 were eliminated from further consideration as project borrow sites. Borrow site 1 , which was good sedimentologically, was also eliminated, based on wave refraction analysis. Mining of any portion of this shoal had the potential to cause wave refraction such that erosion of northern Assateague Island would probably occur.

106. It was recommended at Ocean City that borrow material be extracted singly or in some combination from sites 2, 3, and 4. Total volume of fill required if borrow site 2 is used alone (overfill ratio of 1.02) is $1,395,360 \mathrm{yd}^{3}$. Site 3 (overfill ratio of 1.00 ) used exclusively would require dredging of $1,369,000 \mathrm{yd}^{3}$ for placement on the beach. Site 4 (overfill ratio of 1.23 ) would require $1,682,640 \mathrm{yd}^{3}$.

\section{Volume of Usable Material}

107. Volume of usable sediment in borrow sites 2, 3, and 4 was computed at 5-ft slices. Hydrographic surveys completed prior to this investigation were used to input $\mathrm{x}-, \mathrm{y}-$, and $\mathrm{z}$-coordinates for each borrow site into CPS-1 for volumetric calculations. This program contours the top and bottom of each 5-ft slice of borrow site and then proceeds to calculate volumes in-between. Table 17 summarizes data for the three selected borrow sites. A negative sign in the last column indicates not enough sand is available in that slice to nourish the entire beach and additional depths would have to be used to fulfill project requirements.

108. Volumetric boundaries of borrow site 2 encompass the entire bathymetric survey of shoal 2, which is 1.4 square miles. This borrow site contains sufficient high quality material for the entire project in the slice from 0 to $-40 \mathrm{ft}$ NGVD. A near unity overfill ratio in this slice would allow this shoal to be very economical in terms of yardage mobilized. Below this slice, the remaining shoal contains high quality material that could be used in future projects.

109. Volumetric calculations for borrow site 3 were terminated at the state line and only computed for Maryland's portion of the shoal 3 bathymetric survey. This borrow site has the highest quality borrow material of all potential sources investigated. Each slice has an overfill ratio of unity (Table 17). Sufficient project quantities require dredging to $-45 \mathrm{ft}$ NGVD. All calculations in Table 17 proceed down to elevation of surrounding 
Table 17

Data Summary for Selected Borrow Sites

\begin{tabular}{|c|c|c|c|c|c|}
\hline $\begin{array}{c}\text { Horiz. } \\
\text { Slice } \\
\text { ft/NGVD }\end{array}$ & $\begin{array}{c}\text { Overfill } \\
\text { Ratio } \\
\text { Ra } \\
\end{array}$ & $\begin{array}{l}\text { Renourish } \\
\text { Factor }\end{array}$ & $\begin{array}{r}\text { Ra*Vol. } \\
\text { Required } \\
\times 10^{6} \mathrm{yd}^{3} \\
\end{array}$ & 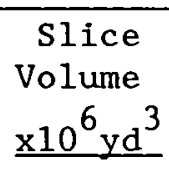 & $\begin{array}{l}\text { Ra*Vol. - } \\
\text { Slice Vol. } \\
\times 10^{6} \mathrm{yd}^{3} \\
\end{array}$ \\
\hline \multicolumn{6}{|c|}{ Borrow Site 2 ( 1.40 square miles) } \\
\hline 0 to -35 & 1.00 & 0.81 & 1.40 & 0.90 & -0.50 \\
\hline 0 to -40 & 1.02 & 1.00 & 1.43 & 3.24 & 1.81 \\
\hline 0 to -45 & 1.07 & 1.10 & 1.50 & 7.41 & 5.91 \\
\hline 0 to -50 & 1.34 & 1.32 & 1.88 & 13.10 & 11.20 \\
\hline \multicolumn{6}{|c|}{ Borrow Site $3(0.68$ square mile) } \\
\hline 0 to -35 & 1.00 & 0.67 & 1.40 & 0.36 & -1.04 \\
\hline 0 to -40 & 1.00 & 0.64 & 1.40 & 1.08 & -0.33 \\
\hline 0 to -45 & 1.00 & 0.75 & 1.40 & 2.32 & 0.92 \\
\hline 0 to -50 & 1.00 & 0.75 & 1.40 & 3.84 & 2.44 \\
\hline \multicolumn{6}{|c|}{ Borrow Site $4(0.58$ square mile) } \\
\hline 0 to -30 & 1.02 & 0.90 & 1.43 & 0.31 & -1.12 \\
\hline 0 to -35 & 1.36 & 1.24 & 1.90 & 1.64 & -0.26 \\
\hline 0 to -40 & 1.23 & 1.13 & 1.72 & 3.50 & 1.77 \\
\hline 0 to -45 & 1.29 & 1.21 & 1.81 & 5.97 & 4.16 \\
\hline
\end{tabular}

topography. Dredging of borrow site 3 could proceed down to $-50 \mathrm{ft}$ NGVD without creating a hole in the seabed.

110. Borrow site 4 bathymetric survey covers two shoals, 4 and 5 . The volumetric boundary for site 4 covers 0.58 square mile. Overfill ratios in this shoal range from 1.02 to 1.36 . Requisite volume of material to fulfill project requirements are not available until $-40 \mathrm{ft}$ NGVD. On adjacent shoal 5, the 0 to $-30 \mathrm{ft}$ NGVD slice contains high quality material; however, it is of insufficient volume to complete the project. Below this level, material quality decreases with calculated overfill ratios greater than 1.7 . Using upper slices of both shoals 4 and 5 would permit borrow site 4 to supply required fill volume with dredging to a reasonable depth. 


\section{Borrow Site Selection}

111. Renourishment factors shown in Table 17 are a measure of how well fill will perform on the beach relative to performance of native sediment. Borrow site 3 , which has renourishment factors less than 1 , will be most stable and require the least renourishment. Upper slices of borrow site 2 also have sufficient sand with renourishment factors less than or equal to 1 to supply the project. In borrow site 4, only the uppermost slice has a renourishment factor less than 1 , and it is not sufficient in volume to complete the entire project. The remainder of shoal 4 could be used, but would not be as desirable. Renourishment factors together with overfill factors suggest that borrow site 3 has the best quality material and should be considered the primary site. Borrow site 2 is next, and borrow site 4 is least desirable based on scientific evidence.

112. Many other economic and political factors must be considered before DNR decides which borrow area(s) to select for the project. From data in Table 17, DNR can determine how much and to what depth dredging would be required on any borrow site to complete the entire project. A best solution might require partial dredging of two borrow sites to minimize distance of fill transport. Whatever borrow sites are used, it is recommended that fill placement proceed from north to south to take advantage of southerly littoral drift and that placement begin in spring to take advantage of natural shoreward sediment movement. 
113. In preparation for a beach nourishment project, CERC investigated native beach and potential borrow site sediment conditions at Ocean City, MD, for the Maryland Department of Natural Resources. This report presents investigation results plus additional comments to suggest improvements over field data collection techniques and data analysis procedures used at Ocean City. In documenting the field work and analysis performed, it is hoped this information will serve as a guide to future beach nourishment field investigations.

114. To determine native beach characteristics, 36 beach profiles were surveyed out to $-36 \mathrm{ft}$ NGVD. Eleven core and grab sediment samples were collected along each profile line. These samples were analyzed for grain size characteristics and development of a composite mean and standard deviation for the beach. Profile data were used to calculate the volume of native material required to fill the beach to design profile specifications.

115. Nine potential offshore borrow sites were examined adjacent to Ocean City. All sites were Holocene age linear shoals common to the entire Delmarva coast. High resolution geophysical surveys and 20 -ft-long vibracores were used to define sedimentological properties of potential borrow sites. Composite borrow site sediment mean and standard deviation were developed for each 5-ft increment of shoal depth down to the level of surrounding topography. Together with detailed hydrographic surveys, borrow site sand volume was calculated.

116. Composite beach grain size distribution statistics were compared with composite statistics for each borrow site to calculate the overfill and renourishment ratios. The volume of fill required for the project from each borrow site was determined. Data analysis reduced the suitable borrow sites down to three choices, which were ranked based on sediment suitability as fill material.

117. As a result of this project, the following general conclusions can be drawn for application to other beach nourishment investigations:

a. If alongshore variation of sediment grain size is considered, beach/nearshore sampling schemes would require only about half the number of samples presently collected and analyzed.

b. Sediment sampling seaward of profile closure depth can be eliminated. Fine-grained materials in this area affect calculation of the composite sample by skewing grain size distributions and composite statistics to finer values, which results 
in a false picture of overfill and renourishment values. This would reduce the length of survey profiles and the number of required samples.

c. Collection of sediment cores on the native beach in place of temporal grab sampling can save time and field costs while maximizing information. Determination of grain size data from core samples is best done by extracting a continuous channel sample along the core length.

d. When defining profile closure depth for sampling or design purposes, the closure position selected should not be based on a short temporal interval of data. Closure depth should be determined from either an interval of representative wave or profile data equal in length to the intended renourishment interval, or equal in intensity to the design storm, or by some other justifiable method which links proposed project behavior to anticipated field conditions.

e. Calculation of fill volumes should include the amount of sediment required to fill the entire profile out to closure depth. Enough sediment should be placed initially so that once the beach has adjusted to its new equilibrium profile, design width is achieved. This will greatly reduce future maintenance costs.

f. When examining borrow sites, a regular spacing of coring sites is best, but when not feasible, a compositing scheme that takes into account spatial inequality of cores should be used.

g. Examination of borrow site data from Ocean City suggests a minimum of 1 core $/ 1,300,000 \mathrm{ft}^{2}$ sampling density for potential borrow sites and a minimum of 1 core/15,000,000 $\mathrm{ft}^{2}$ for exploratory siting. Greater density may be in order for borrow sites in other localities.

h. Shallow penetration, high resolution, subbottom surveys can prove useful for supplementing borrow site core data. Thickness, lateral extent, and inclination of sediments are easily measured on these records.

i. High cost of sedimentological investigations makes it imperative that studies which may eliminate borrow sites from consideration (e.g., wave refraction analysis, environmental inventories, archeological surveys, etc.) be completed prior to commencing sediment data collection. Also, any information that would limit dredging and fill operations in any way (e.g., no dredging below the level of surrounding topography) should be considered in the initial field planning to assure maximum efficiency.

i. At Ocean City, borrow sites 3, 2, and 4, in descending value, were found most suitable to provide the calculated $1.4 \mathrm{mil}$ lion $\mathrm{yd}^{3}$ of fill required to construct the design beach. 


\section{REFERENCES}

Anders, F. J., Underwood, S. G., and Kimball, S. M. 1987. "Beach and Nearshore Sediment Sampling on a Developed Barrier, Fenwick Island, Maryland," Coastal Sediments '87. American Society of Civil Engineers, Vol 2, pp 17321744 .

Belknap, D. F., and Kraft, J. C. 1977. "Holocene Relative Sea-Level Changes and Coastal Stratigraphic Units on the Northwest Flank of the Baltimore Canyon Trough Geosyncline," Journal of Sedimentary Petrology, Vol 47, No. 2, pp 610629.

Birkemeier, William A. 1984. "A User's Guide to ISRP: The Interactive Survey Reduction Program," Instruction Report CERC-84-1, US Army Engineer Waterways Experiment Station, Vicksburg, MS.

1985. "Field Data on Seaward Limit of Profile Change," Journal of Waterway, Port, Coastal and Ocean Engineering, Vol 111, No 3, pp 598-602.

Dean, Robert G. 1974. "Compatibility of Borrow Material for Beach Fills," Proceedings 14th International Conference on Coastal Engineering. American Society of Civil Engineers, Vol II, pp 1319-1330.

DeWall, A. E., and Christenson, J. A. 1984. "Guidelines for Predicting Maximum Nearshore Sand Level Changes on Unobstructed Beaches, " CERC-MP-84-4, US Army Engineer Waterways Experiment Station, Vicksburg, MS.

Dolan, R., Hayden, B., and Jones, C. 1979. "Virginia Barrier Island Configuration," Science, Vo1 204, pp 401-403.

Field, Michael E. 1979. "Sediments, Shallow Subbottom Structure, and Sand Resources of the Inner Continental Shelf, Central Delmarva Peninsula," CERC-TP-79-2. US Army Engineer Waterways Experiment Station, Vicksburg, MS.

Folk, Robert L. 1980. Petrology of Sedimentary Rocks, Hemphill Publishing Company, Austin, TX.

Grosskopf, W. G., and Resio, D.T. 1987. "The Impact of Dredging Offshore Shoals on the Nearshore Environment at Ocean City, Maryland," Offshore and Coastal Technologies, Inc., Fulton, MD.

Hallermeier, Robert J. 1978. "Uses for a Calculated Limit Depth to Beach Erosion," Proceedings, 16th Conference on Coastal Engineering, American Society of Civil Engineers, pp 1493-1512.

. 1981. "A Profile Zonation for Seasonal Sand Beaches from Wave Climate," Coastal Engineering, Vo1 4, pp 253-277.

Hobson, Richard D. 1977. "Review of Design Elements for Beach Fill Evaluation," CERC-TP-77-6, US Army Engineer Waterways Experiment Station, Vicksburg, MS .

Howd, P. A., and Birkemeier, W. A. 1987. "Beach and Nearshore Survey Data: 1981-1984 CERC Field Research Facility," CERC-TR-87-9, US Army Engineer Waterways Experiment Station, Vicksburg, MS.

James, W. R. 1975. "Techniques in Evaluating Suitability of Borrow Material for Beach Nourishment," TM-60, US Army Engineer Waterways Experiment Station, Vicksburg, MS. 
Jensen, Robert. 1983. "Atlantic Coast Hindcast, Shallow Water, Significant Wave Information Report," WIS Report 9, US Army Engineer Waterways Experiment Station, Vicksburg, MS .

Knowles, Stephen, and Byrnes, M. R. "Shoreline Movements, Report 3: Delmarva," Technical Report in preparation, US Army Engineer Waterways Experiment Station, Vicksburg, MS .

Kraft, John C. 1971. "Sedimentary Facies Patterns and Geologic History of a Holocene Marine Transgression," Geological Society of America Bulletin, Vol 82, pp 2131-2158.

Krumbein, W. C., and Greybill, F. A. 1965. An Introduction to Statistical Models in Geology. McGraw-Hill Inc., New York.

Krumbein, W. C., and James, W. R. 1965. "A Lognormal Size Distribution Model for Estimating Stability for Beach Fill Material," TM-16, US Army Engineer Waterways Experiment Station, Vicksburg, MS.

Leatherman, Stephen P. 1979. "Migration of Assateague Island, Maryland, by Inlet and Overwash Processes," Geology, Vol 7, pp 104-107.

Leatherman, S. P., Rice, T. E., and Goldsmith, V. 1982. "Virginia Barrier Island Configuration: A Reappraisal," Science, Vol 215, pp 285-287.

Rice, T. E., Niedoroda, A., and Pratt, A. 1976. The Virginia Coastal Reserve Study, Nature Conservancy, Arlington, VA.

Shore Protection Manual. 1984. 4th ed., 2 Vols, US Army Engineer Waterways Experiment Station, Coastal Engineering Research Center, US Government Printing Office, Washington, DC.

Stauble, Donald K. 1985. "Guidelines for Beach Restoration Projects, Part II Engineering," SGR-77, Florida Sea Grant College, Gainesville, FL.

Stauble, D. K., Hansen, M., and Blake, W. 1984. "An Assessment of Beach Nourishment Sediment Characteristics," Proceedings, 19th Coastal Engineering Conference Proceedings, American Society of Civil Engineers, Pp 1471-1487.

Swift, D. J. P., Duane, D. B., and McKinney, T. F. 1974. "Ridge and Swale Topography of the Middle Atlantic Bight: Seceelo Response to Holocene Hydraulic Regeme," Marine Geology, Vo1 15, pp 227-247.

Truitt, R. V. 1968. "High Winds...High Tides-.A Chronicle of Maryland's Coastal Hurricanes," National Resources Institute, University of Maryland, Educational Series 77, College Park, MD.

Underwood, Steven. 1988. "Sonic Sifting: A Fast and Efficient Method for Sand Size Analysis," CETN-II-14, US Army Engineer Waterways Experiment Station, Vicksburg, MS.

Walton, Todd L. 1977. "Beach Nourishment in Florida and on the Lower Atlantic and Gulf Coast," Technical Paper No. 2, Florida Sea Grant College, Gainesville, FL. 

APPENDIX A

SUMMARY OF NATIVE BEACH SEDIMENT ANALYSIS 



$\begin{array}{llcc}\text { Sample } & X & \mathrm{Y} & \mathrm{Z} \\ \text { Number } & & \text { Location }\end{array}$

Z

Location Mean Std Dev. Skew Kur.

\begin{tabular}{|c|c|c|c|c|c|c|c|}
\hline $0101 \mathrm{AA}$ & 338 & 654 & 6.6 & 1.43 & 0.69 & -0.48 & 5.74 \\
\hline $0101 \mathrm{AE}$ & $=8$ & 654 & 6.17 & 0.7 & 0.57 & 0.12 & 3.75 \\
\hline $0101 \mathrm{AC}$ & 58 & 654 & 6.04 & -0.23 & 0.66 & 0.66 & 4.9 \\
\hline $0101 \mathrm{AD}$ & ذこ日 & 654 & 5.03 & 1.21 & 0.47 & 0.24 & 3.66 \\
\hline $0101 \mathrm{BA}$ & 58 & 654 & 5.55 & 1.42 & 0.45 & 0.36 & 3.34 \\
\hline $0102 \mathrm{AA}$ & 338 & 767 & 6.51 & 1.4 & 0.46 & $\dot{0.08}$ & 2.87 \\
\hline $0102 \mathrm{AB}$ & 3.8 & 767 & 7 & 0.37 & 0.63 & 0.34 & 3.83 \\
\hline $0102 \mathrm{BA}$ & 3.58 & 767 & 2.83 & 1.25 & 0.4 & -0.1 & 7.55 \\
\hline $0102 \mathrm{BE}$ & 338 & 767 & 2.28 & 0.53 & 1.06 & -0.66 & 3.25 \\
\hline $0102 \mathrm{BC}$ & 338 & 767 & 3.75 & 0.75 & 0.66 & -0.14 & 3.53 \\
\hline $0103 A A$ & 3.8 & 808 & 1.4 & 1.08 & 0.88 & -1.5 & 0.09 \\
\hline $0103 \mathrm{AB}$ & 338 & 808 & 1.04 & -0.5 & 0.94 & 0.4 & 3.15 \\
\hline$\because 103 A C$ & 338 & 808 & -0.21 & 1 & 0.74 & -0.16 & 3.25 \\
\hline $0103 A D$ & 338 & 808 & -0.63 & -0.43 & 1.23 & 0.14 & 1.98 \\
\hline O104AA & 338 & $850^{\circ}$ & -0.7 & 0.2 & 1.35 & -0.1 & 2.07 \\
\hline $0104 \mathrm{AB}$ & 338 & 850 & -1.36 & 1.79 & 0.64 & -1.2 & 7.57 \\
\hline 6202AA & 1673 & 591 & 5.7 & 0.9 .3 & 0.61 & -0.02 & $\therefore .42$ \\
\hline $0202 \mathrm{AB}$ & 1675 & 591 & 4.85 & 1.26 & 0.47 & -0.34 & 4.02 \\
\hline O2O2AC & $167:$ & 591 & 2.85 & 0.26 & 1.27 & -0.12 & 2.18 \\
\hline $0202 B A$ & 1673 & 591 & 2.42 & 1.11 & 0.63 & -0.94 & 8.05 \\
\hline \%202BB & 1675 & 591 & 2.26 & 0.57 & 1.1 & -0.82 & 3.3 \\
\hline $0203 A A$ & 1675 & 6.33 & 2.2 & 0.96 & 0.8 & -0.22 & 2.76 \\
\hline $0203 \mathrm{AB}$ & 1673 & 63. & 1.77 & 0.32 & 0.92 & -0.44 & .09 \\
\hline $0204 \mathrm{AA}$ & 1675 & 672 & -1 & 1.47 & 0.94 & -0.86 & 3.05 \\
\hline $0204 \mathrm{AE}$ & 1675 & 672 & -1.92 & -0.72 & 1.39 & 0.74 & 2.4 \\
\hline $0302 A A$ & 2805 & 683 & 8.8 & 0.8 & 0.58 & -0.02 & 3.41 \\
\hline $0303 A A$ & 2805 & 710 & 4.1 & 0.84 & 0.74 & -0.38 & 3.33 \\
\hline $0.303 \mathrm{AE}$ & 2805 & 710 & 3.71 & 0.29 & 1.03 & -0.34 & 2.38 \\
\hline $0304 A A$ & 2805 & 734 & 1.5 & -1.18 & 1.27 & 1.22 & 3.32 \\
\hline $0401 A A$ & 5551 & 466 & 10 & 1.61 & 0.56 & 0.3 & 3.67 \\
\hline $0401 \mathrm{AB}$ & 3551 & 466 & 9.51 & 1.57 & 0.56 & -0.06 & 5.23 \\
\hline $0401 \mathrm{AC}$ & 3551 & 850 & 8.82 & 1.27 & 0.64 & -0.18 & 2.61 \\
\hline $0401 \mathrm{EE}$ & 3551 & 466 & 5.05 & 1.57 & 0.46 & 0.58 & 4.52 \\
\hline 0402AA & 3551 & 556 & 8.4 & 1.19 & 0.62 & 0.14 & J. 14 \\
\hline $0402 \mathrm{AE}$ & 3551 & 556 & 6.14 & 1.39 & 0.5 & 0.16 & 2.93 \\
\hline $0402 \mathrm{BE}$ & 3551 & 556 & 4.56 & 0.69 & 0.93 & -0.14 & 2.94 \\
\hline $040 \Omega A A$ & 5551 & 594 & 4 & 0.08 & 1.05 & -0.32 & 2.65 \\
\hline $040 \mathrm{AE}$ & 2551 & 594 & 3.25 & 1.51 & 0.71 & -0.48 & Z. 52 \\
\hline $0404 A A$ & 2551 & $6 \leq 0$ & -1.5 & -0.5 & 1.68 & 0.4 & 1.5 \\
\hline $0404 \mathrm{AB}$ & 5551 & 630 & -2.75 & 1.38 & 0.58 & -1.36 & 4.98 \\
\hline $0502 A A$ & 495. & 131 & 6.5 & 1.41 & 0.49 & -0.4 & 4.07 \\
\hline $0502 \mathrm{AB}$ & 4953 & 131 & 3.97 & 0.6 & 0.7 & -0.26 & 4.92 \\
\hline $0502 \mathrm{EA}$ & 4953 & $1 \equiv 1$ & 3.18 & 1.26 & 0.45 & 0.46 & 3.34 \\
\hline $0502 \mathrm{BE}$ & 4955 & 151 & 2.15 & 1.05 & 0.81 & -0.89 & 4.12 \\
\hline $0503 A A$ & 4953 & 165 & 2.7 & 1.38 & 0.53 & -0.58 & 4.42 \\
\hline $0504 A A$ & 4953 & 232 & -1.5 & 1.59 & 0.88 & -2.02 & 8.39 \\
\hline $1504 \mathrm{AB}$ & 4955 & 252 & -2.16 & 0.73 & 1.26 & -0.44 & 2.41 \\
\hline $0602 \mathrm{AA}$ & 6000 & 117 & 5.6 & 1.37 & 0.47 & 0.12 & 3.32 \\
\hline $0602 A B$ & 6000 & 117 & 4.91 & 1.22 & 0.55 & 0.02 & 2.47 \\
\hline $0602 \mathrm{BA}$ & 6000 & 117 & 2.35 & 0.69 & 1.02 & -1.14 & 4.52 \\
\hline OSOZEE & 6000 & 117 & 2.06 & 1.3 & 0.65 & -0.8 & 3.74 \\
\hline O6OSAA & 6000 & 152 & 2.7 & 1.27 & 0.5 & -0.18 & 3.23 \\
\hline $060 \mathrm{AE}$ & 6000 & 152 & -0.09 & 0.06 & $1 . \$ 1$ & 0.26 & 2.29 \\
\hline $060 . \mathrm{BA}$ & 6000 & 152 & -0.25 & -0.32 & 1.15 & 0.28 & 2.45 \\
\hline $0604 \mathrm{AA}$ & 6000 & 189 & -0.7 & 1.97 & 0.66 & -0.68 & 4. .34 \\
\hline
\end{tabular}


Sample

$\mathrm{X}$

$\mathrm{Y}$

z

Number

Location

Mean Std Dev.

Skew

Kur.

\begin{tabular}{|c|c|c|c|c|c|c|c|}
\hline $0604 \mathrm{AE}$ & 6000 & 189 & -3.03 & 1.53 & 0.81 & -0.94 & 4.72 \\
\hline $0701 \mathrm{AA}$ & 7002 & 40 & 14.8 & 1.18 & 0.51 & 0.2 & $\Xi .12$ \\
\hline $0701 \mathrm{AB}$ & 7002 & 40 & 12.86 & 0.51 & 0.54 & 1.16 & 4.7 \\
\hline $0701 \mathrm{BA}$ & 7002 & 40 & 11.49 & 1.25 & 0.67 & -0.92 & 6.19 \\
\hline $0702 \mathrm{AA}$ & 7002 & 80 & 5.2 & 1.47 & 0.5 & -0.5 & 3.48 \\
\hline $0702 \mathrm{AB}$ & 7002 & 80 & 3.26 & 0.88 & 0.51 & 0.32 & 3.29 \\
\hline $0702 \mathrm{EA}$ & 7002 & 80 & 1.89 & 1.3 & 0.51 & -0.2 & .9 .97 \\
\hline $0702 \mathrm{BE}$ & 7002 & 80 & 1.66 & 0.66 & 0.79 & -0.58 & 3.82 \\
\hline 070ミAA & 7002 & 98 & 2.2 & 0.79 & 0.74 & -0.44 & 3.67 \\
\hline $0703 \mathrm{AB}$ & 7002 & 98 & -0.1 & 0.05 & 0.96 & 0.06 & 2.93 \\
\hline $070 . \mathrm{B} A C$ & 7002 & 98 & -0.39 & 0.41 & 0.89 & -0.24 & 2.68 \\
\hline $0704 A A$ & 7002 & 118 & -0.2 & 0.43 & 1.04 & -0.14 & 2.54 \\
\hline $0704 \mathrm{AB}$ & 7002 & 118 & -0.4 & 1.48 & 0.75 & -1.8 & 7.6 \\
\hline $0802 \mathrm{AA}$ & 7701 & 67 & 4.9 & 1.27 & 0.54 & -0.98 & 8. 11 \\
\hline $0802 \mathrm{AE}$ & 7701 & 67 & $\$ .06$ & -0.08 & 1.11 & 0.08 & 2.78 \\
\hline $0803 A A$ & 7701 & 85 & 2.9 & 0.81 & 0.98 & -0.76 & .78 \\
\hline $6 B O 3 \mathrm{AB}$ & 7701 & 85 & 1.98 & 1.2 & 0.58 & -0.38 & . 3 \\
\hline $0804 A A$ & 7701 & 106 & 0.6 & 0.98 & 1.01 & -1.1 & 4.16 \\
\hline $0804 \mathrm{AB}$ & 7701 & 106 & 0.24 & -1 & 1.5 & 1.04 & 2.59 \\
\hline $6804 A C$ & 7701 & 106 & -0.52 & -0.14 & 1.29 & 0.08 & 2.05 \\
\hline $0902 A A$ & 9455 & 100 & 6.8 & 1.5 & 0.47 & -0.14 & $\because .46$ \\
\hline $0902 \mathrm{AB}$ & 9455 & 100 & 4.77 & 0.55 & 0.59 & 0.76 & 3.86 \\
\hline $0902 A C$ & 9455 & 100 & 4.41 & 0.35 & 1.17 & 0 & 2.08 \\
\hline $0902 \mathrm{EA}$ & 9455 & 100 & 3.62 & 1.32 & 0.45 & 0.2 & 3.48 \\
\hline $0902 \mathrm{EE}$ & 9455 & 100 & 3.03 & 0.5 & 0.6 & 0.88 & 4.01 \\
\hline $0903 A A$ & 9455 & 121 & 4.1 & 1.35 & 0.49 & -0.44 & 6.38 \\
\hline $0903 \mathrm{AB}$ & 9455 & 121 & 3.51 & 0.85 & 0.74 & -0.36 & 2.97 \\
\hline O904AA & 9455 & 154 & 0.5 & 0.3 & 1.5 & -0.4 & 1.77 \\
\hline $0904 \mathrm{AB}$ & 9455 & 154 & -0.25 & 0.92 & 0.76 & -0.1 & 5.45 \\
\hline $1001 \mathrm{AA}$ & 11205 & 15 & 8 & 1.56 & 0.5 & -0.16 & 5.18 \\
\hline $1001 \mathrm{AE}$ & 11205 & 15 & 4.72 & 1.42 & 0.5 & 0.36 & 3.07 \\
\hline $1002 \mathrm{AA}$ & 11205 & 35 & 6 & 1.44 & 0.59 & 0.22 & 5.53 \\
\hline $1002 \mathrm{AE}$ & 11205 & 35 & 4.85 & 0.89 & 0.75 & 0 & 2.33 \\
\hline $1002 \mathrm{EA}$ & 11205 & 35 & 2.72 & 0.98 & 0.53 & -0.1 & 4.2 \\
\hline $1002 \mathrm{EE}$ & 11205 & 55 & 2.52 & 0.88 & 0.62 & -0.62 & 4.66 \\
\hline $1002 \mathrm{BC}$ & 11205 & 35 & 2.26 & 0.31 & 1.08 & -0.78 & 2.94 \\
\hline $100 \mathrm{AAA}$ & 11205 & 80 & 3.1 & $1 . .55$ & 0.54 & -0.36 & 2.83 \\
\hline $1003 \mathrm{AE}$ & 11205 & 80 & 2.54 & 1.05 & 0.57 & 0.32 & 2.65 \\
\hline $100 \mathrm{SAC}$ & 11205 & 80 & 1.07 & 0.89 & 0.65 & $-0 .>8$ & $\Xi .79$ \\
\hline $1004 \mathrm{AA}$ & 11205 & 139 & -1.8 & 1.65 & 0.69 & -2.18 & 9.75 \\
\hline $1102 \mathrm{AA}$ & 11906 & 95 & 6.5 & $1 . \Xi 7$ & 0.41 & -0.1 & 2.99 \\
\hline $1102 \mathrm{AE}$ & 11906 & 95 & 3.41 & 0.96 & 0.63 & 0.1 & 2.69 \\
\hline $1102 \mathrm{EA}$ & 11906 & 95 & $\therefore .05$ & 0.35 & 0.91 & 0.58 & 2.85 \\
\hline $1102 \mathrm{~EB}$ & 11906 & 95 & 2.89 & -0.03 & 1.08 & 0.94 & 2.94 \\
\hline $1102 \mathrm{ZEC}$ & 11906 & 95 & 2.66 & 1.44 & 0.44 & 0.18 & $\Xi .15$ \\
\hline $1103 \mathrm{AA}$ & 11906 & 134 & 1.8 & 0.9 .5 & 0.73 & -0.58 & $\therefore .25$ \\
\hline $110 . \mathrm{AE}$ & 11906 & $1 \leq 4$ & 0.98 & 1.25 & 0.49 & -0.24 & 6.51 \\
\hline $1104 \mathrm{AA}$ & 11906 & 182 & -2.2 & 1.12 & 0.98 & -1.26 & 4.8 \\
\hline $1104 \mathrm{AE}$ & 11906 & 98 & -2.46 & 1.32 & 0.78 & -0.88 & $\therefore .11$ \\
\hline $1104 \mathrm{AC}$ & 11906 & 182 & -3.54 & 0.73 & 1.12 & -0.28 & 1.95 \\
\hline $1.02 A A$ & 1.3657 & 626 & 5.6 & 1.41 & 0.45 & -0.23 & 3.69 \\
\hline $1302 \mathrm{AB}$ & 1.3657 & 626 & 5.5 & 0.69 & 0.75 & 0.08 & 3.01 \\
\hline $1502 \mathrm{EA}$ & 1.3657 & 626 & 2.32 & 0.30 & 0.7 & -0.02 & 4.17 \\
\hline $1302 \mathrm{EE}$ & 15657 & 626 & 1.86 & 1.21 & 0.45 & 0.4 & 2.83 \\
\hline $1.0 \mathrm{~A} A \mathrm{~A}$ & 1.3657 & 14 & 2.3 & 1.59 & 0.53 & -0.42 & 8.29 \\
\hline $1.0 \mathrm{AB}$ & 13657 & 14 & 0.4 & 0.44 & 0.97 & -0.62 & 3.28 \\
\hline
\end{tabular}




$\begin{array}{llcllll}\text { Sample } & X & Y & Z & & & \\ \text { Number } & & \text { Location } & & \text { Mean } & \text { Std Dev. Skew }\end{array}$

\begin{tabular}{|c|c|c|c|c|c|c|c|}
\hline $1 \Xi 04 A A$ & 15657 & 98 & -1.2 & 0.56 & 1.28 & -1.38 & 2.28 \\
\hline $1 \equiv 04 \mathrm{AB}$ & 13657 & 98 & -1.4 & 2.25 & 0.81 & -1.26 & 7.27 \\
\hline $1304 A C$ & 15657 & 98 & -2.09 & 1.27 & 0.92 & -0.04 & 5.11 \\
\hline $1401 \mathrm{AA}$ & 15246 & 609 & 6.9 & 1.42 & 0.56 & -0.8 & 5.64 \\
\hline $1401 \mathrm{AE}$ & 15246 & 609 & 3.88 & 0.74 & 0.64 & 0.56 & 2.65 \\
\hline $1401 \mathrm{BA}$ & 15246 & 609 & $\Xi .62$ & 1.06 & 0.52 & -0.06 & 4.1 \\
\hline $1401 \mathrm{BE}$ & 15246 & 609 & 2.54 & -0.02 & 1.18 & 0.5 & 2.4 \\
\hline $1402 A A$ & 15246 & 626 & 5.6 & 1.44 & 0.46 & -0.18 & 5.96 \\
\hline $1402 \mathrm{AB}$ & 15246 & 626 & 3.44 & 0.7 & 0.73 & 0.1 & 2.75 \\
\hline $1402 \mathrm{EA}$ & 15246 & 626 & 2.32 & 1.47 & 0.5 & -0.22 & 3.62 \\
\hline $140 \mathrm{SAA}$ & 15246 & 660 & 2.9 & 1.65 & 0.48 & 0.02 & 3.17 \\
\hline $140 . \mathrm{AB}$ & 15246 & 660 & 1.06 & 1.39 & 0.69 & -0.36 & 2.58 \\
\hline $1404 A A$ & 15246 & 737 & -0.8 & 1.35 & 0.99 & -0.78 & 3.26 \\
\hline $1404 \mathrm{AB}$ & 15246 & 757 & -1.1 & 1.80 & 0.84 & -1.82 & 7.49 \\
\hline $1502 A A$ & 16445 & 662 & 5.3 & 1.15 & 0.52 & -0.08 & 2.99 \\
\hline $1502 \mathrm{AE}$ & 16445 & 626 & 4.87 & 1.51 & 0.45 & 0.06 & 5.26 \\
\hline $1502 \mathrm{AC}$ & 16445 & 626 & 4.02 & 1.08 & 0.48 & 0.12 & 2.8 \\
\hline $1502 A D$ & 16445 & 662 & 3.2 & 0.39 & 1.01 & 0.1 & 2.17 \\
\hline $150 \mathrm{AA}$ & 16445 & 705 & 3.4 & 1.55 & 0.44 & -0.66 & 5.89 \\
\hline $150 \mathrm{JAB}$ & 16445 & 705 & 0.87 & 1.09 & 0.76 & -1.72 & 7.66 \\
\hline $1504 \mathrm{AA}$ & 16445 & 752 & -0.7 & 1.61 & 0.57 & -0.32 & 34.54 \\
\hline $1504 \mathrm{AE}$ & 16445 & 752 & -1.88 & 1.12 & 0.9 & -1.02 & 4.01 \\
\hline $1602 A A$ & 17647 & 679 & 5.8 & 1.27 & 0.45 & -0.46 & 4.83 \\
\hline $1602 \mathrm{AE}$ & 17647 & 679 & 3.04 & 1.03 & 1 & -0.98 & 3.46 \\
\hline $1603 \mathrm{AA}$ & 17647 & 701 & 4 & 1.42 & 0.55 & -0.56 & 3.25 \\
\hline $1603 \mathrm{AE}$ & 17647 & 701 & 2.85 & 1.01 & 0.77 & -0.46 & 3.19 \\
\hline $16 \cup \dot{3 A C}$ & 17647 & 701 & 1.54 & 0.37 & 0.81 & -0.9 & 4.00 \\
\hline $1604 \mathrm{AA}$ & 17647 & 749 & 0.2 & 1.11 & 0.78 & -0.62 & 5.01 \\
\hline $1604 \mathrm{AE}$ & 17647 & 736 & -0.46 & 1.61 & 0.61 & -1.62 & 7.98 \\
\hline $1701 \mathrm{AA}$ & 18546 & 665 & 7.6 & 1.7 & 0.5 & 0.26 & 3.89 \\
\hline $1701 \mathrm{AB}$ & 18546 & 665 & 6.06 & 1.16 & 0.54 & 0.28 & 3.6 \\
\hline $1701 \mathrm{AC}$ & 18546 & 665 & 5.7 & 2.1 & 0.62 & 0 & 2.6 \\
\hline $1701 \mathrm{AD}$ & 18546 & 665 & 5.5 & 0.64 & 0.71 & 0.72 & 4.18 \\
\hline $1701 \mathrm{BA}$ & 18546 & 665 & 4.32 & 1.64 & 0.45 & 0.5 & 3.97 \\
\hline $1701 \mathrm{BE}$ & 18546 & 665 & 3.57 & 0.96 & 0.62 & -0.2 & 2.78 \\
\hline $1701 \mathrm{EC}$ & 18546 & 665 & 2.78 & 1.27 & 0.46 & -0.34 & 4.18 \\
\hline $1702 \mathrm{AA}$ & 18546 & 711 & 7.1 & 1.36 & 0.46 & -0.36 & 5.02 \\
\hline $170 . \mathrm{AA}$ & 18546 & 741 & 3 & 1.15 & 0.51 & 0.06 & 3.24 \\
\hline $1703 \mathrm{AB}$ & 18546 & 741 & 2.15 & 1.22 & 0.52 & -0.4 & 3.45 \\
\hline $1704 \mathrm{AA}$ & 18546 & 790 & -0.7 & 0.96 & 0.87 & -0.68 & 3.26 \\
\hline $1802 \mathrm{AA}$ & 19778 & 645 & 7.1 & 1.24 & 0.51 & -0.48 & 4.91 \\
\hline $180 \Xi A A$ & 19778 & 689 & 1.7 & 0.91 & 0.68 & -0.7 & 5.86 \\
\hline $180 \Xi \mathrm{AE}$ & 19778 & 689 & 1.11 & -0.26 & 1.2 & -0.04 & 1.94 \\
\hline $1804 \mathrm{AA}$ & 19778 & 716 & -1.7 & 1.1 & 0.89 & -1.14 & 4.18 \\
\hline $1804 \mathrm{AE}$ & 19778 & 725 & -2.22 & 1.22 & 0.63 & -1.08 & 5.96 \\
\hline $1804 \mathrm{AC}$ & 19778 & 725 & -3.47 & 0.35 & 1.51 & -0.52 & 1.9 \\
\hline $1902 \mathrm{AA}$ & 20978 & 750 & 5.8 & 1.24 & 0.45 & -0.42 & 5.11 \\
\hline $1902 \mathrm{EA}$ & 20978 & 750 & 2.72 & 0.62 & 0.75 & -0.12 & 2.6 \\
\hline $1902 \mathrm{EE}$ & 20978 & 750 & 2.19 & 1.24 & 0.44 & 0.26 & 5.57 \\
\hline $190 \mathrm{AAA}$ & 20978 & 784 & 2.4 & 1.14 & 0.78 & -1.26 & 5.08 \\
\hline $190 \mathrm{BAE}$ & 20978 & 784 & 0.37 & 0.13 & 1.1 & -0.32 & 2.56 \\
\hline $1904 \mathrm{AA}$ & 20978 & $8: 7$ & -1.6 & 1.49 & 1.06 & -2.02 & 6.4 \\
\hline $2001 \mathrm{AA}$ & 22479 & 695.7 & 8.2 & 1.54 & 0.52 & -0.38 & 3.63 \\
\hline $2001 \mathrm{AE}$ & 22479 & 695 & 6.95 & 1.88 & 0.61 & -0.1 & 3.78 \\
\hline $2001 \mathrm{EA}$ & 22479 & 695 & 4.92 & 1.2 & 0.5. & -0.52 & 5.88 \\
\hline $2002 \mathrm{AA}$ & 22479 & 728.5 & 7.2 & 1.29 & 0.44 & -0.2 & 4.12 \\
\hline
\end{tabular}




$\begin{array}{llcllll}\text { Sample } & X & Y & Z & & & \\ \text { Number } & X & \text { Meation } & & \text { Std Dev. Skew }\end{array}$

\begin{tabular}{|c|c|c|c|c|c|c|c|}
\hline $2002 A B$ & 22479 & 728.5 & 5.3 & 0.74 & 0.68 & -0.36 & 4.01 \\
\hline $2002 \mathrm{EA}$ & 22479 & 728.5 & 4.12 & 1.29 & 0.5 & -0.1 & 3.72 \\
\hline $2003 A A$ & 22479 & 768.5 & 4.6 & 1.14 & 0.59 & -1.16 & 7.01 \\
\hline $2003 \mathrm{AB}$ & 22479 & 768.5 & 2.27 & -0.01 & 1.25 & -0.04 & 1.82 \\
\hline $2004 A A$ & 22479 & 808.2 & 0 & 1.03 & 0.85 & -1.3 & 5.52 \\
\hline $2004 \mathrm{AE}$ & 22479 & 808.2 & -1.28 & -0.91 & 1.74 & 0.98 & 2.25 \\
\hline $2102 \mathrm{AA}$ & 23983 & 657 & 6.6 & 1.41 & 0.47 & -0.92 & 6.73 \\
\hline $2102 \mathrm{AE}$ & 23983 & 657 & 4.53 & 0.49 & 0.98 & -0.68 & 3.15 \\
\hline $2102 \mathrm{EA}$ & 23983 & 668 & 3.94 & 0.78 & 0.93 & -1.24 & 5.1 \\
\hline $210 \mathrm{BAA}$ & 23983 & 721.8 & 2.5 & 1.25 & 0.61 & -0.76 & 4.49 \\
\hline $210 \mathrm{BAE}$ & 23983 & 721.8 & 2.34 & 0.04 & 1.1 & -0.14 & 2.18 \\
\hline $2104 \mathrm{AA}$ & 23983 & 813.5 & -2.1 & 0.82 & 0.94 & -0.78 & 3.3 \\
\hline $2202 \mathrm{AA}$ & 25485 & 516.2 & 15.8 & 1.26 & 0.51 & -0.46 & 4.15 \\
\hline $2203 A A$ & 25485 & 557.3 & 11.9 & 1.23 & 0.7 & -1.54 & 7.21 \\
\hline $2204 \mathrm{AA}$ & 25485 & 604.2 & 6.1 & 1.02 & 0.72 & -0.78 & 4.17 \\
\hline $2301 \mathrm{AA}$ & 26985 & 417.7 & 8.8 & 1.27 & 0.75 & -1.26 & 5.94 \\
\hline $2301 \mathrm{BA}$ & 26985 & 417.7 & 6.01 & 1.59 & 0.48 & -0.24 & 5 \\
\hline $2301 \mathrm{~EB}$ & 26985 & 417.7 & 5.0. & 2.07 & 0.58 & -0.36 & 4.93 \\
\hline $2302 A A$ & 26985 & 4.5 .1 & 6.3 & 1.34 & 0.59 & -1.3 & 7.5 \\
\hline $2302 \mathrm{EA}$ & 26985 & 456.1 & 5.45 & 1.55 & 0.42 & 0.06 & 6.45 \\
\hline $2302 \mathrm{~EB}$ & 26985 & $4: 0.1$ & $\therefore .05$ & 1.9 .3 & 0.57 & -0.18 & 4.19 \\
\hline $2302 B C$ & 26985 & 436.1 & 2.82 & 0.84 & 0.76 & -0.42 & 3.32 \\
\hline $2303 A A$ & 26985 & 467.5 & 3.5 & 0.62 & 0.68 & -0.3 & 3.18 \\
\hline $2303 \mathrm{AB}$ & 26985 & 467.5 & $\Xi .04$ & 1.56 & 0.56 & -0.48 & 3.89 \\
\hline $2303 A C$ & 26985 & 467.5 & 2.09 & -0.47 & 1.54 & 0.32 & 1.58 \\
\hline $2304 \mathrm{AA}$ & 26985 & 512.5 & 0.8 & 0.91 & 1.12 & -1.18 & 3.63 \\
\hline $2402 \mathrm{AA}$ & 28485 & 540 & 6.1 & 1.22 & 0.57 & -0.64 & 4.26 \\
\hline $2403 A A$ & 28485 & 570.6 & 3.7 & 1.32 & 0.61 & -1.12 & 8.8 \\
\hline $240 \mathrm{AB}$ & 28485 & 570.6 & 2.91 & 0.57 & 1.09 & -0.58 & 2.72 \\
\hline $2404 A A$ & 28485 & 609.6 & -0.3 & -1.13 & 1.2 & 1.12 & . 18 \\
\hline $2404 \mathrm{AB}$ & 28485 & 609.6 & -0.63 & 1.02 & 0.89 & -1.04 & 4.55 \\
\hline $2502 A A$ & 29886 & 389.5 & 5.8 & 1.17 & 0.56 & -1 & 5.28 \\
\hline $250 . \mathrm{AA}$ & 29886 & 403.5 & 4.4 & 1.02 & 0.68 & -1.02 & 5.06 \\
\hline $2504 \mathrm{AA}$ & 29886 & 431.2 & 1.1 & 0.46 & 0.99 & -0.58 & 2.82 \\
\hline $2601 \mathrm{AA}$ & 31483 & 499 & 7.4 & 1.46 & 0.54 & -0.42 & 4.27 \\
\hline $2601 \mathrm{AB}$ & 31483 & 499 & 5.4 & 1.05 & 1.02 & -0.62 & 2.82 \\
\hline $2601 \mathrm{EA}$ & 31483 & 499 & 4.55 & 1.39 & 0.45 & -0.14 & 4.29 \\
\hline $2601 \mathrm{~EB}$ & 31483 & 499 & 3.79 & 0.67 & 1.06 & -0.96 & 3.63 \\
\hline $2602 \mathrm{AA}$ & 51483 & 533 & 7.4 & 1.02 & 0.74 & -1.44 & 7.58 \\
\hline $2603 A A$ & $\$ 1485$ & 556 & 4.8 & 0.92 & 0.59 & -0.68 & 5.28 \\
\hline $2603 \mathrm{AB}$ & 31483 & 556 & 3.13 & -0.31 & 1.76 & 0.28 & 1.75 \\
\hline $2604 \mathrm{AA}$ & 31483 & 585.1 & 1.2 & -0.11 & 1.39 & -0.16 & 1.77 \\
\hline $2702 \mathrm{AA}$ & 52569 & 458 & 7.3 & 1.11 & 0.63 & -1.16 & 5.84 \\
\hline $2702 \mathrm{EA}$ & 32569 & 458 & 4.09 & 0.9 & 0.89 & -0.88 & $\therefore .82$ \\
\hline $2702 \mathrm{BE}$ & 32569 & 458 & 3.69 & 1.64 & 0.56 & -1.54 & 9.36 \\
\hline $2703 \mathrm{AA}$ & $=2569$ & 488 & $\Xi .4$ & 0.82 & 0.92 & -0.56 & 3.68 \\
\hline $270 \Omega \mathrm{AE}$ & $\$ 2569$ & 488 & 5.04 & 1.2 & 0.52 & -0.58 & 6.42 \\
\hline $2703 A C$ & 32569 & 488 & 1.69 & 0 & 1.23 & -0.2 & 1.98 \\
\hline $2704 \mathrm{AA}$ & 52569 & 516.5 & -0.5 & $-1.6=$ & 0.71 & 2.12 & 8.16 \\
\hline $2802 A A$ & 54005 & $57 \Xi$ & 7.1 & 1.28 & 0.56 & -0.82 & 5.39 \\
\hline $2802 \mathrm{AE}$ & 34005 & 573 & 6.12 & 0.01 & 1.05 & -0.42 & 2.78 \\
\hline $280 . \mathrm{AA}$ & .4005 & 606 & $\Xi .6$ & 0.99 & 0.61 & -0.88 & 5.3 .3 \\
\hline $2805 \mathrm{AB}$ & $\$ 4005$ & 606 & 3.27 & -0.76 & 1.2 & 0.3 & 1.86 \\
\hline $2804 \mathrm{AA}$ & 54005 & 640 & -0.1 & 0.51 & 1.14 & -0.68 & 2.87 \\
\hline $2804 \mathrm{AB}$ & 54005 & 640 & -0.4 .5 & -1.23 & 0.79 & 0.8 & 3.58 \\
\hline $2804 A C$ & 34005 & 640 & -1.12 & -1.95 & 0.51 & :.84 & 20.89 \\
\hline
\end{tabular}




\begin{tabular}{|c|c|c|c|c|c|c|c|}
\hline $\begin{array}{l}\text { Sample } \\
\text { Number }\end{array}$ & $\mathrm{X}$ & $\begin{array}{c}\mathrm{Y} \\
\text { Location }\end{array}$ & $\mathrm{Z}$ & Mean & Std Dev. & Skew & Kur. \\
\hline $2804 A D$ & 3.4005 & 640 & -1.41 & -0.21 & 1.35 & 0.1 & 1.98 \\
\hline $\begin{array}{l}2901 \mathrm{AA} \\
2901 \mathrm{AB}\end{array}$ & $\begin{array}{l}35470 \\
35470\end{array}$ & $\begin{array}{l}502 \\
502\end{array}$ & $\begin{array}{r}6.8 \\
5.85\end{array}$ & $\begin{array}{l}1.07 \\
1.54\end{array}$ & $\begin{array}{l}0.62 \\
0.49\end{array}$ & $\begin{array}{l}-0.4 \\
0.26\end{array}$ & $\begin{array}{r}3.5 \\
3.46\end{array}$ \\
\hline $2902 \mathrm{AA}$ & 35470 & 5.36 & 6.3 & 1.61 & 0.38 & 0.52 & 4.22 \\
\hline $2902 \mathrm{AE}$ & 55470 & 536 & 5.61 & 0.57 & 1.01 & -0.86 & 3.45 \\
\hline $2903 A A$ & 35470 & 565 & 3.5 & 1.22 & 0.54 & -0.2 & 4.3 \\
\hline $2903 \mathrm{AB}$ & 55470 & 565 & 2.61 & -0.01 & 1.5 & -0.32 & 1.91 \\
\hline $2904 A A$ & 35470 & 597 & 0 & -0.99 & 1.46 & 0.9 & 2.24 \\
\hline $3002 A A$ & 36489 & 607.5 & 6.4 & 1.15 & 0.62 & -1.04 & 4.68 \\
\hline $3003 A A$ & 36489 & 624 & 5.1 & 1.21 & 0.74 & -1.86 & 8.05 \\
\hline S004AA & 56489 & 651 & 2.1 & 0.93 & 0.78 & -0.9 & 4.85 \\
\hline $3102 \mathrm{AA}$ & 37862 & 623.7 & 6.8 & 1.01 & 0.57 & -0.68 & 4.18 \\
\hline$\Xi 103 A A$ & 37862 & 653.7 & 4 & 1.08 & 0.44 & -0.54 & 5.26 \\
\hline$\Xi 10 \mathrm{AE}$ & 37862 & 65.7 & $=.08$ & 0.46 & 0.95 & -0.94 & 3.7 \\
\hline$\$ 104 A A$ & 37862 & 691.8 & 0 & 0.88 & $1.0 \mathrm{~J}$ & -1.12 & 4.01 \\
\hline $3104 \mathrm{AE}$ & 3.7862 & 691.8 & -0.46 & -1.08 & 1.14 & 0.8 & 2.44 \\
\hline $3201 \mathrm{AA}$ & 39336 & 615.5 & 6.7 & 1.35 & 0.58 & -0.88 & 0.05 \\
\hline $3201 \mathrm{BA}$ & 39336 & 615.3 & 3.42 & 0.98 & 0.75 & -1.16 & 5.59 \\
\hline $3202 A A$ & 39.56 & 639.6 & 5.6 & 1.45 & 0.52 & -0.46 & 5.42 \\
\hline $520.5 A A$ & 5956 & 663.9 & 3.5 & 1.28 & 0.54 & -0.72 & 5.54 \\
\hline$\$ 203 A B$ & 39336 & 663.9 & 2.06 & 0.36 & 0.96 & -0.74 & 3.24 \\
\hline$\Xi 204 \mathrm{AA}$ & 39336 & 699.2 & -0.1 & -0.3 & 1.3 & 0.36 & 1.91 \\
\hline $3204 \mathrm{AE}$ & 39336 & 699.2 & -0.92 & 1.12 & 0.61 & -0.82 & 5.53 \\
\hline$\Xi 302 A A$ & 41186 & 621 & 6.6 & 1.21 & 0.5 & -0.68 & 5.49 \\
\hline उ3OSAA & 41186 & 511 & 3.5 & 0.99 & 0.51 & -1.36 & 9.44 \\
\hline $330 \mathrm{AB}$ & 41186 & 658.5 & 1.66 & 0.64 & 0.63 & -0.64 & 4.91 \\
\hline $5303 \mathrm{BA}$ & 41186 & 658.5 & 0.94 & 0.37 & 0.98 & -0.96 & 3.57 \\
\hline$\Xi 304 A A$ & 41186 & 695.4 & 0 & 0.22 & 1.18 & -0.44 & 2.4 \\
\hline $304 \mathrm{AE}$ & 41186 & 695.4 & -1.34 & 1.19 & 0.71 & -1.36 & 6.55 \\
\hline $5402 A A$ & 4.30 .37 & 672 & 6.8 & 1.51 & 0.43 & -0.56 & 6.81 \\
\hline$\$ 40 \mathrm{JAA}$ & 430.37 & 706 & 4.3 & 1.09 & 0.66 & -1.86 & 9.09 \\
\hline $3404 A A$ & 4.3037 & 731 & 1.1 & 0.08 & 1.23 & -0.58 & 2.15 \\
\hline $3404 \mathrm{AE}$ & 43037 & 731 & 0.44 & 1.28 & 0.47 & -1.26 & 9.31 \\
\hline $3501 \mathrm{AA}$ & 4446. & 655 & 7 & 1.2 & 0.46 & -0.3 & .72 \\
\hline $3502 \mathrm{AA}$ & 44465 & 675 & 7 & 1.57 & 0.43 & -0.08 & 3.55 \\
\hline $3503 \mathrm{AA}$ & 44463 & 700 & 4.1 & 1.11 & 0.53 & -0.98 & 5.31 \\
\hline $3504 A A$ & 44463 & 724 & 0.8 & 0.56 & 0.73 & -0.42 & 4.01 \\
\hline $3504 \mathrm{AB}$ & 44463 & 724 & 0.05 & 1.27 & 0.45 & -0.44 & 7.58 \\
\hline $3602 A A$ & 45959 & 718 & 0.7 & 1.23 & 0.46 & -0.48 & 6.33 \\
\hline$\$ 602 \mathrm{AB}$ & 45959 & 718 & 5.78 & 0.78 & 1.1 & -1.2 & 4.1 \\
\hline$\$ 60.3 A A$ & 45959 & $750^{\circ}$ & 4 & 0.5 & 0.99 & -0.6 & 2.86 \\
\hline$\Xi 60 \Omega \mathrm{AE}$ & 45959 & 750 & 3.64 & 1.17 & 0.51 & -1.48 & 9.3 \\
\hline$\$ 604 A A$ & 45959 & 784 & -0.4 & -1.27 & 1.1 & 1.12 & 3.12 \\
\hline $3604 \mathrm{AE}$ & 45959 & 784 & -1.65 & 0.57 & 1.11 & -0.7 & 2.79 \\
\hline$\$ 701 \mathrm{AA}$ & 47409 & 605 & 6.9 & 1.25 & 0.51 & -0.92 & 8.64 \\
\hline$\triangle 702 \mathrm{AA}$ & 47409 & 6.57 & 0.6 & 1.31 & 0.46 & -0.34 & 4.18 \\
\hline$\Xi 703 A A$ & 47409 & 660 & 2.7 & 0.83 & 0.75 & -1.1 & 5.36 \\
\hline $370 . \mathrm{AE}$ & 47409 & 660 & 1.19 & 1.27 & 0.38 & -0.52 & 10.72 \\
\hline $370 . \mathrm{AC}$ & 47409 & 660 & 0.86 & -0.29 & 1.2 & -0.22 & 1.85 \\
\hline $5704 \mathrm{AA}$ & 47409 & 690 & -0.5 & 0.87 & 0.62 & 0.54 & 3.52 \\
\hline 010500 & 330 & 950 & -4.9 & 2.05 & 0.78 & -0.94 & $\Xi .87$ \\
\hline 010600 & 388 & 1067 & -8.8 & 1.99 & 0.62 & -0.92 & 6.62 \\
\hline 010700 & 58 & 1250 & -16 & $=45$ & 0.71 & -2.64 & 18.51 \\
\hline 010800 & 38 & 13.1 & -19.5 & 2.15 & 0.67 & -0.3 .2 & 7.45 \\
\hline 010900 & 388 & 4261 & -14.2 & 1.72 & 0.31 & 0.94 & 5.78 \\
\hline 011100 & 58 & 4899 & -19.8 & 1.49 & 0.49 & 0.6 & 3.31 \\
\hline
\end{tabular}




$\begin{array}{llccccc}\text { Sample } & \mathrm{X} & \mathrm{Y} & \mathrm{Z} & & & \\ \text { Number } & & \text { Location } & & \text { Mean } & \text { Std Dev. Skew }\end{array}$

\begin{tabular}{|c|c|c|c|c|c|c|c|}
\hline 020500 & 1673 & 969 & -9.9 & 1.05 & $1: 33$ & -0.78 & 2.86 \\
\hline 020600 & 1673 & 1035 & -12 & 2.56 & 0.55 & -2.04 & 14.99 \\
\hline 050500 & 2805 & 796 & -1.2 & 1.42 & 0.8 & -0.74 & 3.72 \\
\hline 0.0600 & 2805 & 961 & -5.3 & 2.25 & 0.6 & -0.52 & 4.71 \\
\hline 040500 & 3551 & 867 & -5.2 & 1.7 & 0.76 & -1 & 5.66 \\
\hline 040600 & 3551 & 1200 & -13.8 & 3.04 & 0.5 & -3.04 & 24.23 \\
\hline 040700 & 3551 & 1775 & -19 & 2.72 & 0.4 .5 & -0.58 & 5.38 \\
\hline 040800 & 3551 & 2653 & -25.2 & 3.13 & 0.51 & -0.08 & 3.21 \\
\hline 040900 & 3551 & 3149 & -29.5 & 3.09 & 0.48 & -1.1 & 7.36 \\
\hline 041000 & 3551 & 4610 & -25.2 & 1.84 & 0.41 & 0.9 & 6.16 \\
\hline 041100 & 5551 & 6158 & -23.6 & 1.8 & 0.73 & -0.02 & 3.65 \\
\hline 050500 & $495 \Xi$ & 287 & -3.4 & 1.76 & 0.67 & -0.3 & 3.52 \\
\hline 050600 & 495.3 & 583 & -10.8 & 2.09 & 0.83 & -0.68 & 4.1 \\
\hline 060500 & 6000 & 582 & -5 & 1.75 & 0.61 & -0.56 & 3.67 \\
\hline 060600 & 6000 & 519 & -9.7 & 1.98 & 0.63 & -0.34 & 4.01 \\
\hline 070500 & 7002 & 146 & -2.8 & 1.79 & 0.67 & -1.38 & 8.4 \\
\hline 070600 & 7002 & 440 & -9.5 & 2.59 & 0.56 & -2.28 & 16.48 \\
\hline 070700 & 7002 & 610 & -16.3 & 2.55 & 0.72 & -0.84 & 3.98 \\
\hline 070800 & 7002 & 851 & -23.6 & 2.06 & 1.01 & -0.2 & 2.38 \\
\hline 070900 & 7002 & 1260 & -27.7 & 1.06 & 0.87 & -0.52 & 6.27 \\
\hline 071000 & 7002 & 2498 & -32.6 & 3.58 & 0.52 & -0.58 & 2.96 \\
\hline 071100 & 7002 & $\Xi 148$ & -34.8 & $\$ .76$ & 0.76 & -2.78 & 10.6 \\
\hline 080500 & 7701 & 314 & -4.9 & 2.11 & 0.5 & -0.68 & 7.64 \\
\hline 080600 & 7701 & 520 & -12.3 & 1.74 & 0.87 & -2.2 & 10.25 \\
\hline 090500 & 9455 & 214 & -4.1 & -0.18 & 1.51 & 0.16 & 1.72 \\
\hline 090600 & 9455 & 481 & -8.7 & 1.83 & 0.71 & -0.96 & 5.68 \\
\hline $100500^{\circ}$ & 11205 & 223 & -5.5 & 2.32 & 0.47 & 0.02 & 6.62 \\
\hline 100600 & 11205 & 458 & -8.8 & 1.6 .5 & 0.61 & 0.16 & 3.57 \\
\hline 100700 & 11205 & 611 & -14.9 & 2.42 & 0.6 & -0.64 & 5.51 \\
\hline 100000 & 11205 & 935 & -21.5 & 5.27 & 0.41 & 0.2 & 3.41 \\
\hline 100900 & 11205 & 1367 & -25.4 & 2.72 & 0.68 & $-1 . .56$ & 8.07 \\
\hline 101000 & 11205 & 2216 & -51.6 & 3.42 & 0.44 & -0.28 & 3.77 \\
\hline 101100 & 11205 & 3940 & -.56 .6 & 3.57 & 0.75 & -2.02 & 8.2 \\
\hline 110500 & 11906 & 205 & -4 & 0.46 & 1.59 & -0.54 & 1.8 \\
\hline 110600 & 11906 & 519 & -8.6 & 2.04 & 0.67 & -1.24 & 日. 3 \\
\hline 130500 & 13657 & 166 & -5.1 & 2.2 & 0.76 & -1.82 & 9.82 \\
\hline 1.30600 & 15657 & 336 & -6 & 1.56 & 0.95 & -0.68 & 4.22 \\
\hline 140500 & 15246 & 767 & -2.8 & 2 & 0.56 & -0.14 & క.55 \\
\hline 140600 & 15246 & 1056 & -8.4 & 2.7 & 0.46 & -0.74 & 5.95 \\
\hline $14070^{\circ}$ & 15246 & 1245 & -15.1 & 2.97 & 0.53 & -0.78 & 5.49 \\
\hline 140800 & 15246 & 1799 & -22.1 & 2.73 & 0.56 & 0.02 & 3.67 \\
\hline 140900 & 15246 & 2377 & -27.3 & $\Xi$ & 0.59 & -0.44 & 4.56 \\
\hline 141000 & 15246 & 3380 & $-3 \mathbf{3}$. & 3.08 & 0.71 & -1.28 & 8.31 \\
\hline 141100 & 15246 & 4573 & -36.8 & 1.78 & 0.67 & -0.66 & 4.68 \\
\hline $150500^{\circ}$ & 16445 & 824 & -3.7 & 2.11 & 0.62 & -1.48 & 8.53 \\
\hline 150600 & 16445 & 11.30 & -9.1 & 1.91 & 0.71 & -0.54 & 5.25 \\
\hline 160500 & 17647 & 790 & -1.8 & 1.32 & 0.85 & -1.42 & 4.91 \\
\hline 160600 & 17647 & 1035 & -6.4 & 1.66 & 0.69 & -0.94 & 5.95 \\
\hline $170500^{\circ}$ & 18546 & $84:$ & -2.1 & 1.99 & 0.49 & -2.16 & 20.31 \\
\hline 170600 & 18546 & 1197 & -10.5 & 1.7 & 0.82 & -1.26 & 6.84 \\
\hline 170800 & 18546 & 1570 & -20.8 & 2.53 & 0.54 & 0.3 & 3.23 \\
\hline 170900 & 18546 & 2057 & -24.7 & 2.33 & 0.58 & 0.4 & 4 \\
\hline 171000 & 18546 & 2974 & -50.4 & 2.59 & 0.67 & -2.04 & 15.28 \\
\hline 171100 & 18546 & 4629 & -35 & 2.61 & 0.63 & -1.9 & 13.33 \\
\hline 180500 & 19778 & 786 & -5.3 & 1.79 & 0.61 & -1.58 & 8.21 \\
\hline 180600 & 19778 & 1077 & -11.2 & 2.55 & 0.63 & -1.50 & 7.13 \\
\hline
\end{tabular}


$\mathrm{Y} \quad \mathrm{Z}$

Location Mean Std Dev. Skew Kur.

\begin{tabular}{|c|c|c|c|c|c|c|c|}
\hline 190500 & 20978 & 876 & -4.4 & 2.26 & 0.4 & 0.46 & 3.44 \\
\hline 190600 & 20978 & 1102 & -7.4 & 1.82 & 0.6 & -0.42 & 4.07 \\
\hline 200500 & 22479 & 818 & -1.2 & -0.61 & 1.56 & 0.54 & 1.76 \\
\hline 200600 & 22479 & 983 &.- .7 & 1.85 & 0.75 & -0.58 & \\
\hline 200700 & 22479 & 1201 & -11.1 & 2.63 & 1.15 & -2.9 & 11.57 \\
\hline 200800 & 22479 & 1341 & -15.6 & 3.23 & 0.38 & -2.24 & 22. \\
\hline 200900 & 22479 & 1916 & -21.8 & 3.22 & 0.68 & -4.14 & 28.0 \\
\hline 201000 & 22479 & 2584 & -29.4 & 2.68 & 1.39 & -0.56 & 1.8 \\
\hline 201100 & 22479 & 4863 & $-\$ 6.3$ & 2.39 & 0.63 & -1.02 & 6.2 \\
\hline 210500 & 23983 & 819 & -2.2 & 1.47 & 0.6 & -0.82 & 4. \\
\hline 220600 & 25485 & 1028 & -10.4 & 1.82 & 1.11 & -2.06 & 7.5 \\
\hline $230500^{\circ}$ & 26985 & 576 & -4.8 & 1.82 & 0.76 & -1.14 & 5.0 \\
\hline 230600 & 26985 & 784 & -9.3 & 1.51 & 0.95 & -1.42 & 6.6 \\
\hline 230700 & 26985 & 973 & -16.1 & 2.71 & 0.54 & -1.16 & 8.6 \\
\hline 230800 & 26985 & $126 \Xi$ & -21.1 & 2.38 & 0.64 & -0.26 & 3.8 \\
\hline 230900 & 26985 & 2568 & -28.8 & 3.29 & 0.47 & -1.6 & 12.8 \\
\hline 231000 & 26985 & 5105 & -28.4 & 2.22 & 0.38 & -0.56 & 5.9 \\
\hline 231100 & 26985 & 5754 & -36.8 & 2.47 & 0.41 & -0.66 & 7.8 \\
\hline 240500 & 28485 & 674 & -1.5 & 1.77 & 0.64 & -0.56 & 4.6 \\
\hline 240600 & 28485 & 859 & -8.8 & 1.12 & 1.02 & -0.86 & 3.9 \\
\hline 250500 & 29886 & 523 & -1.9 & 1.67 & 0.69 & -0.36 & 4.1 \\
\hline 250600 & 29886 & 559 & -2.7 & 1.97 & 0.7 & -0.94 & 6.2 \\
\hline 260500 & $\Xi 148 \Xi$ & 622 & -2.4 & 1.87 & 0.69 & -0.7 & 4.6 \\
\hline 260600 & 3148.3 & 727 & -5.6 & 1.78 & 0.67 & -0.66 & 4.7 \\
\hline 260700 & 3148 & 999 & -14.4 & 3.12 & 0.38 & -0.62 & 5.0 \\
\hline $260800^{\circ}$ & $\$ 1483$ & 1311 & -19.8 & 2.91 & 0.52 & -1 & 6.0 \\
\hline 260900 & 31483 & 1995 & -27.6 & 3.05 & 0.76 & -2.32 & 10.4 \\
\hline 261000 & 31483 & 3978 & -3̇.9 & 2.54 & 0.35 & 0.72 & \\
\hline 261100 & $\Xi 1485$ & 4209 & -37 & 2.58 & 0.57 & -1.6 & 17.1 \\
\hline 270500 & 52569 & 589 & -2.1 & 1.66 & 0.97 & -2.12 & 8.0 \\
\hline 270600 & 32569 & 758 & -8.3 & 2.16 & 0.8 & -1.5 & 7.3 \\
\hline 280500 & 34005 & 668 & -0.8 & 1.65 & 0.79 & -0.66 & 3.7 \\
\hline 280600 & 34005 & 785 & -4.2 & 1.72 & 0.65 & -1 & 6. \\
\hline 290500 & .5470 & 649 & -1.7 & 2.23 & 0.59 & -0.48 & 5.9 \\
\hline 290600 & 35470 & 849 & -8.4 & 2.1 & 0.61 & -0.68 & 6.0 \\
\hline 290700 & 35470 & 10.36 & -16.5 & 2.57 & 0.6 & -0.96 & 5.7 \\
\hline 290800 & 55470 & 13.2 & -24.8 & -0.29 & 1.16 & 1.24 & 6.7 \\
\hline 290900 & 55470 & 2057 & -28.1 & 2.15 & 0.86 & -1.1 & 6.1 \\
\hline 291000 & 35470 & 4995 & -28.4 & 2.17 & $0.4 \Xi$ & -0.84 & 6.5 \\
\hline 291100 & 55470 & 5474 & -36.7 & 2.55 & 0.37 & -0.64 & 8.8 \\
\hline 300500 & 56489 & 702 & -1.9 & 1.69 & 0.73 & -1.6 & 8.6 \\
\hline$\$ 00600$ & 36489 & 884 & -6.2 & 1.22 & 1.08 & -0.66 & 3.0 \\
\hline 310600 & 37862 & 935 & -7.6 & 2.21 & 0.67 & -0.96 & 6. \\
\hline$\$ 10500$ & 37862 & 935 & -7.6 & 1.88 & 0.51 & -0.6 & 6.1 \\
\hline .20500 & 39336 & 724 & -0.2 & 0.95 & 0.93 & -0.44 & 3.3 \\
\hline 320600 & 39336 & 859 & -4.3 & 1.76 & 0.94 & -1.2 & 5.0 \\
\hline 320700 & 39.36 & 105. & -11.3 & 2.4 & 0.58 & -0.3 & 3.2 \\
\hline 520800 & .9336 & 1289 & -20.4 & 2.72 & 0.68 & $-1 . \pm 6$ & 8.0 \\
\hline 320900 & 39.36 & 1775 & -26.4 & 3.22 & 0.62 & -0.62 & 6.9 \\
\hline 321000 & 39.36 & 2707 & -33 & 3.14 & 0.84 & 0.02 & 1.5 \\
\hline 221100 & 39.36 & $3 \Xi 16$ & -35.9 & 2.84 & 0.92 & -0.68 & 4.1 \\
\hline 330600 & 41186 & 872 & -7.2 & 1.69 & 0.72 & -0.5 & 3.4 \\
\hline 340500 & 4.3057 & 758 & 0 & -0.11 & 1.4 & 0.12 & 1.8 \\
\hline $340600^{\circ}$ & 4.30 .57 & 998 & -6.1 & 1.09 & 0.92 & -0.74 & \\
\hline 350500 & 44463 & 807 & -1.5 & 1.69 & 0.61 & -0.68 & 4. \\
\hline 350600 & 44463 & 924 & -5 & 1.53 & 0.87 & -1 & 5.0 \\
\hline
\end{tabular}


$\begin{array}{llcllll}\begin{array}{l}\text { Sample } \\ \text { Number }\end{array} & X & \begin{array}{c}\text { Y } \\ \text { Location }\end{array} & & \text { Mean } & \text { Std Dev. Skew }\end{array}$

350800

350900

351000

551100

360500

560600

$\$ 70500$

$\$ 70600$

370700

570800

$\$ 70900$

$\$ 71000$

$\$ 71100$

$\begin{array}{lr}44463 & 1145 \\ 44463 & 1451 \\ 44463 & 1656 \\ 44465 & 2225 \\ 44463 & 4516 \\ 45959 & 921 \\ 45959 & 961 \\ 47409 & 787 \\ 47409 & 904 \\ 47409 & 1054 \\ 47409 & 1176 \\ 47409 & 1322 \\ 47409 & 1690 \\ 47409 & .414\end{array}$

$\begin{array}{rr}-13.2 & 2.17 \\ -21.9 & 2.65 \\ -25 & 1.54 \\ -30.4 & 1.65 \\ -38.5 & 2.35 \\ -0.9 & 1.75 \\ -5.6 & 1.81 \\ -3.5 & 1.74 \\ -6.1 & 1.78 \\ -12.7 & 2.16 \\ -17.4 & 2.36 \\ -21.6 & 1.23 \\ -28.6 & 2.81 \\ -37.8 & 0.93\end{array}$

0.74

0.62

0.47

0.55

0.37

0.67

0.81

0.76

0.64

0.65

0.79

0.95

0.76

0.75

-0.8
-0.46
-0.38
-0.12
-0.44
-1.2
-1.48
-1.8
-0.38
-0.32
-1.84
-0.62
-1.14
0.66

4.78

3.69

5.38

4.29

12.45

7.42

8. 18

9.53

4.11

3.67

10.82

5.32

7.53

4.81 
APPENDIX B

SUMMARY OF BORROW SITE SEDIMENT ANALYSIS 



\begin{tabular}{|c|c|c|c|c|c|}
\hline $\begin{array}{c}\text { Shoal/Core/Sample } \\
\text { Number } \\
\end{array}$ & $\begin{array}{c}\text { Core Interval } \\
(\mathrm{Ft} .) \\
\end{array}$ & Mean & Std. Dev. & Skew. & Kurt. \\
\hline $01-01-A$ & $0-7.2$ & 2.844 & 0.655 & -0.672 & 6.075 \\
\hline $01-02-A$ & $\begin{array}{ll}0 & -13.1\end{array}$ & 2.305 & 0.560 & -1.018 & 5.788 \\
\hline $01-03-A$ & $0-3.6$ & 1.955 & 0.716 & -0.73 & 4.444 \\
\hline $01-03-B$ & $3.6-4.8$ & 1.322 & 1.005 & -0.86 & 4.218 \\
\hline $01-03-E$ & $6.5-10.2$ & 2.310 & 0.847 & -0.1 & 2.920 \\
\hline $01-03-F$ & $10.2-12.5$ & 2.123 & 1.377 & -0.012 & 2.086 \\
\hline $01-04-A$ & $0-2.6$ & 2.309 & 0.690 & -0.182 & 2.993 \\
\hline $01-04-B$ & $2.6-3.1$ & 0.877 & 0.828 & -0.092 & 4.307 \\
\hline $01-04-C$ & $9.0-11.0$ & 1.554 & 0.528 & -0.03 & 6.875 \\
\hline $01-05-A$ & $0-8.7$ & 1.633 & 0.734 & -2.098 & 11.157 \\
\hline $01-06-A$ & $0-1.1$ & 0.589 & 1.180 & -0.212 & 2.582 \\
\hline $01-06-B$ & $1.1-9.9$ & 1.339 & 0.659 & -0.248 & 4.763 \\
\hline $01-06-C$ & $9.9-12.9$ & 1.999 & 0.630 & -0.282 & 5.488 \\
\hline 01-07-A & $0-4.6$ & 2.653 & 0.776 & -1.258 & 5.291 \\
\hline $01-07-B$ & $6.2-9.4$ & 3.278 & 0.468 & -1.342 & 13.726 \\
\hline $01-07-C$ & $9.4-11.5$ & 0.891 & 1.910 & 0.172 & 2.07 \\
\hline $01-08-A$ & $0-2.1$ & 1.227 & 1.008 & -1.288 & 4.906 \\
\hline $01-08-B$ & $2.1-17.5$ & 1.978 & 0.532 & -0.454 & 5.642 \\
\hline $01-09-A$ & $0-2.0$ & 0.854 & 1.259 & -0.828 & 3.016 \\
\hline $01-09-B$ & $2.0-15.1$ & 1.586 & 0.600 & -0.038 & 3.924 \\
\hline $02-01-A$ & $0-7.3$ & 2.411 & 1.132 & -1.738 & 7.607 \\
\hline $02-01-B$ & $7.3-11.3$ & 1.127 & 1.082 & -0.256 & 3.839 \\
\hline $02-01-C$ & $11.3-14.8$ & 2.648 & 0.859 & -0.706 & 6.968 \\
\hline $02-01-D$ & $14.8-15.4$ & -0.143 & 1.703 & 0.688 & 2.594 \\
\hline $02-01-E$ & $15.4-19.4$ & 2.747 & 1.230 & -0.654 & 2.844 \\
\hline $02-02-A$ & $0-0.3$ & 2.352 & 0.570 & -2.142 & 13.353 \\
\hline $02-02-B$ & $0.3-3.4$ & 2.390 & 0.644 & -1.458 & 8.213 \\
\hline $02-02-C$ & $3.4-4.7$ & 0.259 & 0.988 & -0.418 & 3.978 \\
\hline $02-02-D$ & $4.7-10.0$ & 2.557 & 0.974 & -1.076 & 5.422 \\
\hline $02-02-E$ & $10-12.0$ & 1.994 & 0.894 & -1.098 & 6.523 \\
\hline $02-02-F$ & $12.0-14.2$ & 2.358 & 0.525 & -0.732 & 12.776 \\
\hline $02-03-A$ & $\begin{array}{ll}0 & -10.3\end{array}$ & 2.117 & 0.567 & -1.630 & 9.752 \\
\hline $02-03-B$ & $10.3-15.5$ & 1.978 & 0.538 & -0.424 & 8.628 \\
\hline $02-04-A$ & $0-5.5$ & 2.167 & 0.603 & -1.144 & 7.773 \\
\hline $02-04-B$ & $5.5-6.5$ & 2.525 & 0.702 & -1.534 & 9.404 \\
\hline $02-04-C$ & $6.5-10.8$ & 2.604 & 0.872 & -1.088 & 5.995 \\
\hline $02-04-D$ & $10.8-11.5$ & 1.510 & 1.341 & -0.234 & 3.165 \\
\hline $02-04-E$ & $11.5-17.7$ & 1.476 & 1.052 & -0.252 & 4.039 \\
\hline $02-04-F$ & $17.7-19.6$ & 0.007 & 1.613 & 0.410 & 2.415 \\
\hline $02-05-A$ & $\begin{array}{ll}0 & -17.1\end{array}$ & 1.947 & 0.537 & -1.226 & 10.147 \\
\hline $02-06-A$ & $0-2.5$ & 1.438 & 0.705 & -1.590 & 9.484 \\
\hline $02-06-B$ & $2.5-6.6$ & 2.417 & 0.920 & -2.264 & 11.291 \\
\hline $02-06-C$ & $6.6-10.8$ & 2.384 & 1.215 & -1.396 & 5.766 \\
\hline $02-06-D$ & $10.8-18.5$ & 1.995 & 0.838 & -0.690 & 5.792 \\
\hline $02-07-A$ & $0-2.0$ & 1.853 & 0.465 & -0.976 & 7.774 \\
\hline $02-07-B$ & $2.0-12.2$ & 2.001 & 0.393 & -0.360 & 6.271 \\
\hline $02-07-C$ & $12.2-12.4$ & 1.595 & 0.666 & -1.320 & 8.957 \\
\hline $02-07-D$ & $12.4-15.3$ & 2.122 & 0.433 & -0.034 & 5.226 \\
\hline
\end{tabular}




\begin{tabular}{|c|c|c|c|c|c|}
\hline $\begin{array}{c}\text { Shoal/Core/Sample } \\
\text { Number } \\
\end{array}$ & $\begin{array}{c}\text { Core Interval } \\
(\mathrm{Ft} .)\end{array}$ & Mean & Std. Dev. & Skew. & Kurt. \\
\hline $02-07-E$ & $15.3-17.1$ & 2.131 & 0.509 & -0.684 & 7.816 \\
\hline $02-07-F$ & $17.1-19.0$ & 2.451 & 0.602 & -1.656 & 11.756 \\
\hline $02-08-A$ & $0-14.5$ & 1.672 & 1.060 & -0.720 & 4.092 \\
\hline $02-08-B$ & $14.5-18.2$ & 2.473 & 1.167 & -1.094 & 4.934 \\
\hline $02-08-C$ & $18.2-19.8$ & 2.426 & 0.752 & -0.908 & 8.087 \\
\hline $02-09-A$ & $0-12.6$ & 1.157 & 0.609 & -0.636 & 5.908 \\
\hline $02-10-A$ & $0-9.4$ & 2.392 & 0.625 & -1.560 & 11.435 \\
\hline $02-10-B$ & $9.4-15.5$ & 2.908 & 0.907 & -0.770 & 4.981 \\
\hline $02-10-C$ & $15.5-20.0$ & 1.730 & 0.822 & -1.122 & 6.134 \\
\hline $02-11-A$ & $0-2.3$ & 1.138 & 0.497 & -0.512 & 9.150 \\
\hline $02-11-B$ & $2.3-3.9$ & 0.086 & 1.253 & -0.044 & 2.401 \\
\hline $02-11-C$ & $3.9-8.6$ & 1.903 & 0.871 & -1.492 & 5.821 \\
\hline $02-12-A$ & $0-1.0$ & 0.830 & 1.176 & -0.036 & 3.777 \\
\hline $02-12-B$ & $1.0-7.7$ & 2.483 & 0.987 & -1.178 & 6.367 \\
\hline $02-12-C$ & $7.7-10.7$ & 2.967 & 1.164 & -0.914 & 4.188 \\
\hline $02-12-D$ & $10.7-19.7$ & 2.343 & 0.686 & -0.508 & 6.397 \\
\hline $02-13-A$ & $0-9.8$ & 2.100 & 0.590 & -1.424 & 7.690 \\
\hline $02-13-B$ & $9.8-14.6$ & 2.320 & 0.642 & -1.660 & 10.434 \\
\hline $02-13-c$ & $14.6-15.1$ & 2.551 & 0.812 & -1.974 & 12.547 \\
\hline $02-13-D$ & $15.1-16.4$ & 2.628 & 0.595 & -0.508 & 9.893 \\
\hline $03-06-A$ & $\begin{array}{ll}0 & -13.9\end{array}$ & 0.643 & 0.907 & -0.486 & 3.949 \\
\hline $03-06-B$ & $13.9-21.9$ & 0.923 & 0.955 & -0.052 & 2.897 \\
\hline $03-07-A$ & $0 \quad-$ ??? & 0.211 & 1.191 & -0.634 & 2.823 \\
\hline $03-07-B$ & ??? - ??? & 0.797 & 0.777 & -0.128 & 3.686 \\
\hline $03-07-C$ & ??? - ??? & 0.773 & 0.857 & -0.164 & 4.069 \\
\hline $03-07-D$ & ??? - ??? & 0.736 & 0.946 & 0.358 & 3.689 \\
\hline $03-09-\mathrm{A}$ & $\begin{array}{ll}0 & -11.4\end{array}$ & 0.633 & 0.897 & -0.534 & 4.296 \\
\hline $03-10-A$ & $0 \quad-12.2$ & 1.432 & 0.981 & -0.664 & 4.600 \\
\hline $03-10-B$ & $12.2-12.7$ & 1.608 & 1.392 & -0.132 & 1.983 \\
\hline $03-10-C$ & $12.7-14.0$ & 2.128 & 0.826 & -1.344 & 10.727 \\
\hline $03-12-A$ & $0-1.6$ & 1.815 & 0.744 & -0.032 & 5.910 \\
\hline $03-12-B$ & $1.6-2.2$ & 1.727 & 0.605 & 1.350 & 8.773 \\
\hline $03-12-C$ & $2.2-3.4$ & 1.698 & 0.844 & -1.742 & 8.828 \\
\hline $03-12-D$ & $3.4-6.7$ & 2.434 & 1.035 & -0.770 & 5.975 \\
\hline $03-12-E$ & $6.7-10.6$ & 3.014 & 0.790 & -1.362 & 6.618 \\
\hline $03-12-F$ & $16.4-18.6$ & 0.296 & 1.615 & 0.224 & 1.848 \\
\hline $04-01-A$ & $\begin{array}{ll}0 & -13.4\end{array}$ & 2.077 & 0.577 & -1.340 & 7.429 \\
\hline $04-01-B$ & $13.4-15.4$ & 2.349 & 0.692 & -0.804 & 6.480 \\
\hline $04-01-C$ & $15.4-16.2$ & 0.154 & 1.710 & 0.450 & 2.278 \\
\hline $04-01-D$ & $16.2-19.3$ & 2.289 & 0.781 & -1.184 & 8.770 \\
\hline $04-02-A$ & $0-3.8$ & 2.404 & 0.539 & -1.560 & 11.411 \\
\hline $04-02-B$ & $3.8-5.9$ & 2.066 & 1.715 & -1.222 & 3.845 \\
\hline $04-02-C$ & $5.9-7.2$ & 3.033 & 1.509 & -1.618 & 5.104 \\
\hline $04-02-D$ & $7.2-7.9$ & 1.969 & 1.701 & -0.994 & 3.461 \\
\hline $04-02-E$ & $7.9-10.5$ & 2.288 & 0.840 & -0.098 & 5.840 \\
\hline $04-02-F$ & $10.5-11.9$ & 1.892 & 1.462 & -0.098 & 1.968 \\
\hline $04-02-G$ & $11.9-14.0$ & 2.747 & 0.853 & -0.726 & 5.367 \\
\hline $04-02-\mathrm{H}$ & $14.0-19.0$ & 3.012 & 1.344 & -1.050 & 3.424 \\
\hline $04-02-I$ & $19.0-19.9$ & 2.474 & 0.625 & -0.146 & 6.642 \\
\hline
\end{tabular}


Shoal/Core/Sample

Number

04-03-A

$04-03-B$

04-04-A

04-04-B

04-05-A

04-05-B

04-05-C

04-05-D

04-05-E

04-06-A

04-06-B

04-08-A

04-08-B

04-08-C

$04-08-D$

04-09-A

05-01-A

05-02-A

05-02-B

$05-02-C$

05-03-A

05-04-A

$05-04-B$

05-04-C

05-04-D

05-04-E

05-04-F

$06-01-A$

06-02-A

$06-02-C$

06-02-D

$06-03-A$

06-03-B

06-03-C

06-03-D

06-03-E

06-03-F

06-03-G

06-03-H

06-04-A

06-04-B

06-04-C

06-05-A

06-05-B

06-06-A

06-07-A

07-01-C

01-01-E

07-01-F
Core Interval

\begin{tabular}{|c|c|c|c|c|}
\hline$(\mathrm{Ft})$. & Mean & Std. Dev. & Skew. & Kurt. \\
\hline $0-8.6$ & 1.692 & 0.541 & -0.300 & 6.057 \\
\hline $8.6-10.8$ & 0.805 & 0.943 & 0.426 & 7.119 \\
\hline $0-1.0$ & 2.240 & 1.244 & -1.462 & 6.181 \\
\hline $1.0-1.7$ & 2.972 & 1.857 & -1.758 & 5.024 \\
\hline $0-1.6$ & 1.368 & 2.084 & -0.582 & 1.936 \\
\hline $1.6-5.4$ & 2.429 & 1.291 & -1.386 & 6.047 \\
\hline $5.4-7.2$ & 2.959 & 1.605 & -1.382 & 4.126 \\
\hline $7.2-11.4$ & 1.427 & 1.171 & 0.118 & -2.676 \\
\hline $11.4-12.6$ & 2.541 & 1.315 & -0.084 & 2.066 \\
\hline $0-3.3$ & 2.160 & 0.509 & -1.064 & 6.929 \\
\hline $3.3-8.5$ & 2.918 & 0.589 & 0.544 & 3.536 \\
\hline $0-1.0$ & 1.755 & 0.857 & -1.960 & 8.571 \\
\hline $1.0-6.3$ & 2.215 & 0.560 & -1.618 & 10.807 \\
\hline $6.3-8.7$ & 0.911 & 1.419 & -0.300 & -2.408 \\
\hline $8.7-15.5$ & 2.484 & 0.789 & 0.040 & 3.928 \\
\hline $0-11.6$ & 1.790 & 1.291 & -1.324 & 5.599 \\
\hline $0-3.5$ & 1.315 & 1.276 & 0.204 & 3.450 \\
\hline $0-10.3$ & 1.808 & 0.529 & -0.662 & 7.174 \\
\hline $10.3-12.5$ & 2.806 & 1.090 & -1.450 & 5.939 \\
\hline $12.5-17.8$ & 2.756 & 0.840 & -0.216 & 3.069 \\
\hline $0-9.8$ & 1.960 & 0.796 & -1.418 & 6.398 \\
\hline $0-9.8$ & 1.655 & 0.573 & -1.054 & 7.729 \\
\hline $9.8-10.5$ & 2.490 & 0.548 & -0.222 & 6.406 \\
\hline $10.5-12.0$ & 3.073 & 0.739 & -1.398 & 8.360 \\
\hline $12.0-13.5$ & 3.013 & 1.379 & -1.502 & 5.172 \\
\hline $13.5-16.4$ & 2.342 & 1.044 & -1.608 & 8.342 \\
\hline $16.4-19.0$ & 2.694 & 0.975 & -0.250 & 2.548 \\
\hline $0-7.5$ & 2.441 & 0.521 & -1.396 & 10.123 \\
\hline $0-1.9$ & 2.899 & 0.944 & -0.868 & 4.910 \\
\hline $9.8-13.1$ & 2.701 & 0.886 & -0.492 & 3.929 \\
\hline $13.1-17.0$ & 1.233 & 1.270 & 0.070 & 3.015 \\
\hline $\begin{array}{ll}0 & -0.82\end{array}$ & 1.584 & 0.467 & -1.244 & 8.224 \\
\hline $0.8-2.2$ & 1.025 & 0.604 & -0.432 & 3.689 \\
\hline $2.2-4.0$ & 1.515 & 0.453 & -1.414 & 8.679 \\
\hline $4.0-4.7$ & 1.628 & 0.389 & -0.488 & 5.739 \\
\hline $4.7-9.9$ & 1.417 & 0.624 & 1.594 & 9.324 \\
\hline $10-13.2$ & 1.462 & 0.639 & -0.732 & 6.139 \\
\hline $13.2-14.3$ & 1.405 & 0.894 & -1.730 & 6.986 \\
\hline $14.3-16.5$ & 1.420 & 0.576 & -0.704 & 7.201 \\
\hline $0-3.3$ & 1.869 & 0.611 & -1.478 & 7.956 \\
\hline $3.3-12.2$ & 2.202 & 0.548 & -0.386 & 7.246 \\
\hline $17.9-19.5$ & 2.737 & 0.838 & -1.346 & 10.421 \\
\hline $0-6.5$ & 2.376 & 0.575 & -1.670 & 9.718 \\
\hline $6.6-16.1$ & 2.145 & 0.718 & -1.424 & 8.166 \\
\hline $0 \quad-15.5$ & 2.138 & 0.554 & -1.498 & 7.746 \\
\hline $\begin{array}{ll}0 & -19.7\end{array}$ & 1.769 & 0.669 & -0.972 & 5.078 \\
\hline $8.9-9.3$ & 2.464 & 0.456 & -0.660 & 9.057 \\
\hline $10.1-16.1$ & 1.952 & 1.199 & -0.174 & 2.980 \\
\hline $16.1-18.0$ & 2.254 & 1.107 & -0.562 & 3.669 \\
\hline
\end{tabular}




\begin{tabular}{|c|c|c|c|c|c|}
\hline $\begin{array}{c}\text { Shoal/Core/Sample } \\
\text { Number } \\
\end{array}$ & $\begin{array}{c}\text { Core Interval } \\
(\mathrm{Ft} .)\end{array}$ & Mean & Std. Dev. & Skew. & Kurt. \\
\hline $07-01-G$ & $18.0-19.6$ & 2.382 & 0.674 & -2.29 & 15.108 \\
\hline $07-02-A$ & $0-6.6$ & 2.322 & 0.628 & -1.730 & 11.914 \\
\hline $07-02-B$ & $9.3-19.0$ & 2.463 & 0.798 & 0.574 & 4.235 \\
\hline $07-03-c$ & $4.4-8.9$ & 3.065 & 0.975 & -0.132 & 1.821 \\
\hline $07-03-D$ & $8.9-4.2$ & 1.939 & 0.838 & -0.800 & 4.432 \\
\hline $07-04-A$ & $0-6.6$ & 2.117 & 0.953 & -1.456 & 6.255 \\
\hline $07-04-B$ & $6.6-9.5$ & 2.208 & 1.537 & -1.138 & 4.336 \\
\hline $07-04-C$ & $9.5-9.9$ & 2.169 & 0.601 & 0.348 & 5.991 \\
\hline $07-04-E$ & $13.3-15.1$ & 1.418 & 1.130 & -0.806 & 3.436 \\
\hline $07-04-F$ & $15.4-16.2$ & 1.716 & 1.438 & -0.876 & 2.715 \\
\hline $07-04-G$ & $16.2-17.5$ & 2.143 & 1.005 & -1.388 & 5.060 \\
\hline $08-02-A$ & $0-2.9$ & 2.136 & 1.062 & -1.162 & 6.294 \\
\hline $08-02-B$ & $2.9-5.0$ & 1.257 & 1.917 & -0.310 & 1.853 \\
\hline $08-02-C$ & $5.0-7.1$ & 3.154 & 0.710 & -3.486 & 24.815 \\
\hline $08-02-D$ & $7.1-9.7$ & 0.889 & 1.709 & 1.446 & 4.315 \\
\hline $08-02-E$ & $9.7-16.0$ & 1.912 & 0.964 & 0.970 & 3.924 \\
\hline $08-02-F$ & $16.0-16.9$ & 0.911 & 1.430 & 0.052 & 3.308 \\
\hline $08-02-G$ & $16.9-18.6$ & 1.726 & 1.093 & 0.668 & 4.285 \\
\hline $08-04-\mathrm{H}$ & $10.9-11.6$ & 3.498 & 0.520 & -0.844 & 5.323 \\
\hline $08-05-B$ & $0.5-2.3$ & 1.907 & 1.018 & -1.366 & 6.945 \\
\hline $08-05-C$ & $2.3-6.2$ & -0.683 & 1.412 & 0.850 & 3.348 \\
\hline $08-05-D$ & $6.2-10.6$ & 2.237 & 1.029 & -1.196 & 5.600 \\
\hline $08-05-E$ & $10.6-13.1$ & 3.120 & 0.740 & -4.296 & 27.503 \\
\hline $08-05-F$ & $13.1-15.7$ & -0.287 & 2.028 & 0.992 & 2.694 \\
\hline $08-05-G$ & $15.7-20.3$ & 3.037 & 0.865 & -1.084 & 5.938 \\
\hline $09-01-A$ & $\begin{array}{ll}0 & -19.0\end{array}$ & 1.150 & 0.603 & -0.026 & 6.260 \\
\hline $09-02-A$ & $\begin{array}{ll}0 & -15.7\end{array}$ & 2.177 & 0.473 & -1.410 & 10.947 \\
\hline $09-03-A$ & $\begin{array}{ll}0 & -13.1\end{array}$ & 1.875 & 0.435 & -1.220 & 10.954 \\
\hline
\end{tabular}


APPENDIX C

HYDROGRAPHIC SURVEY EXAMPLES OF BORROW SITE 2 WITH 5-FT CONTOURS AND DREDGING LIMITS 



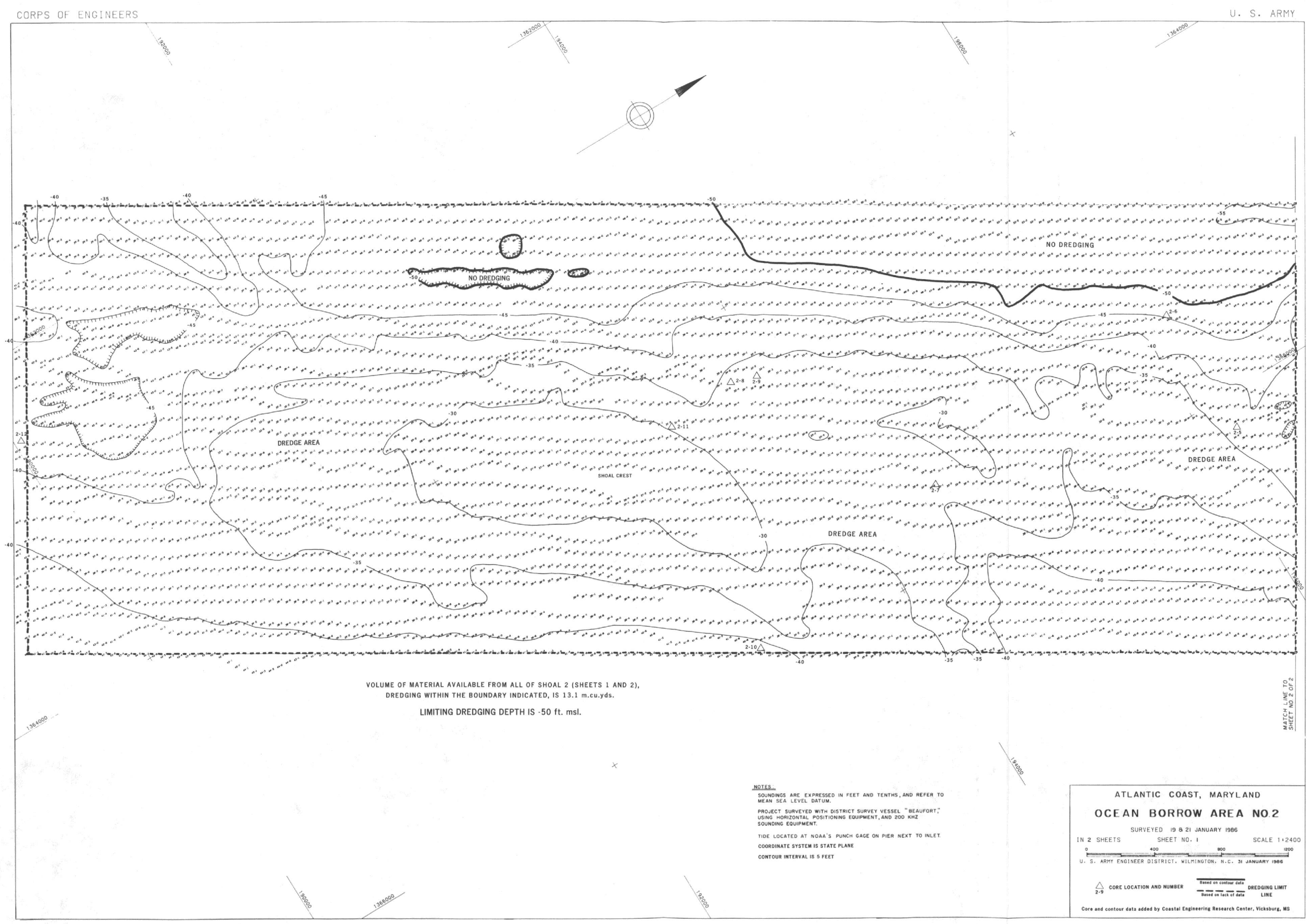





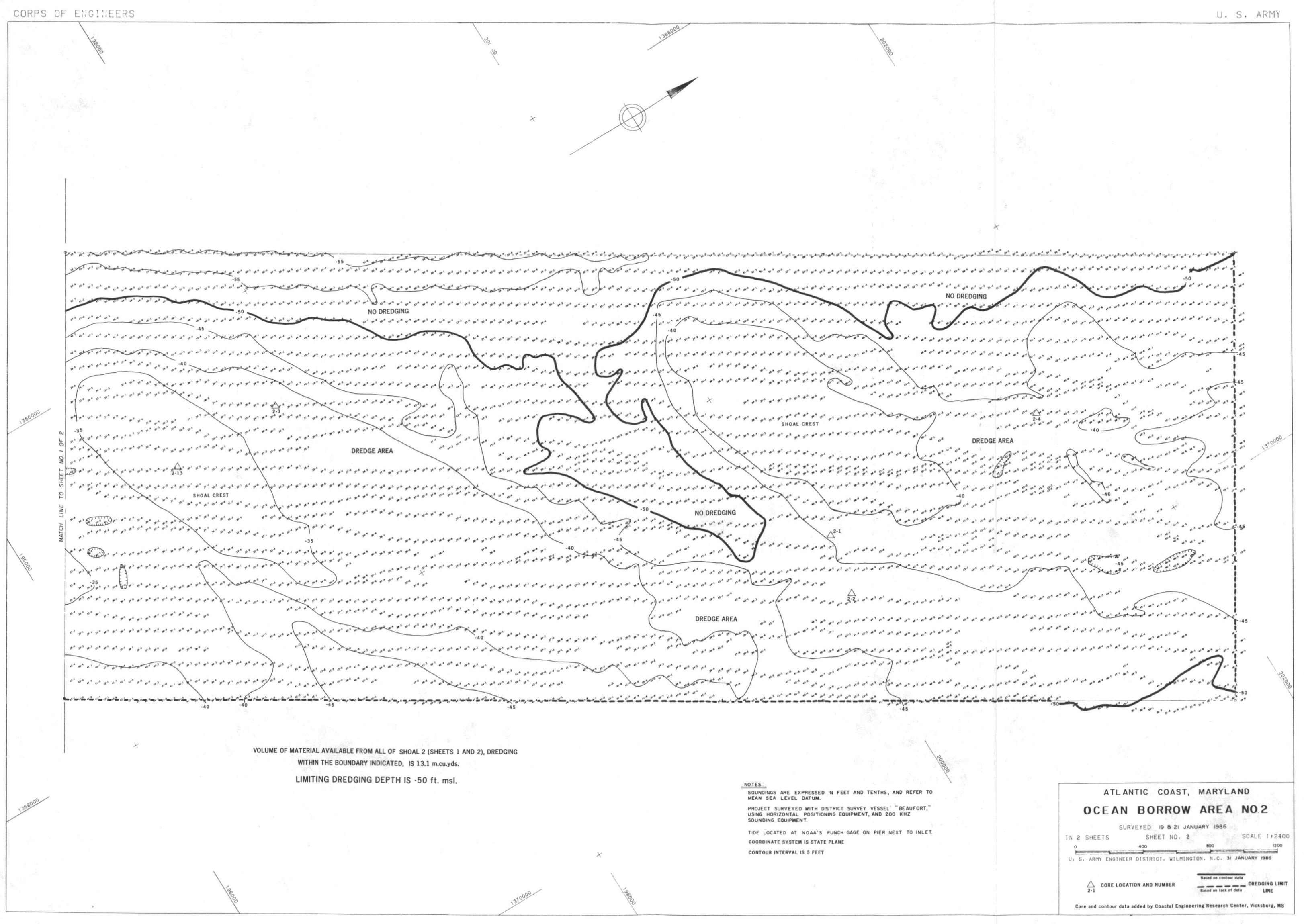






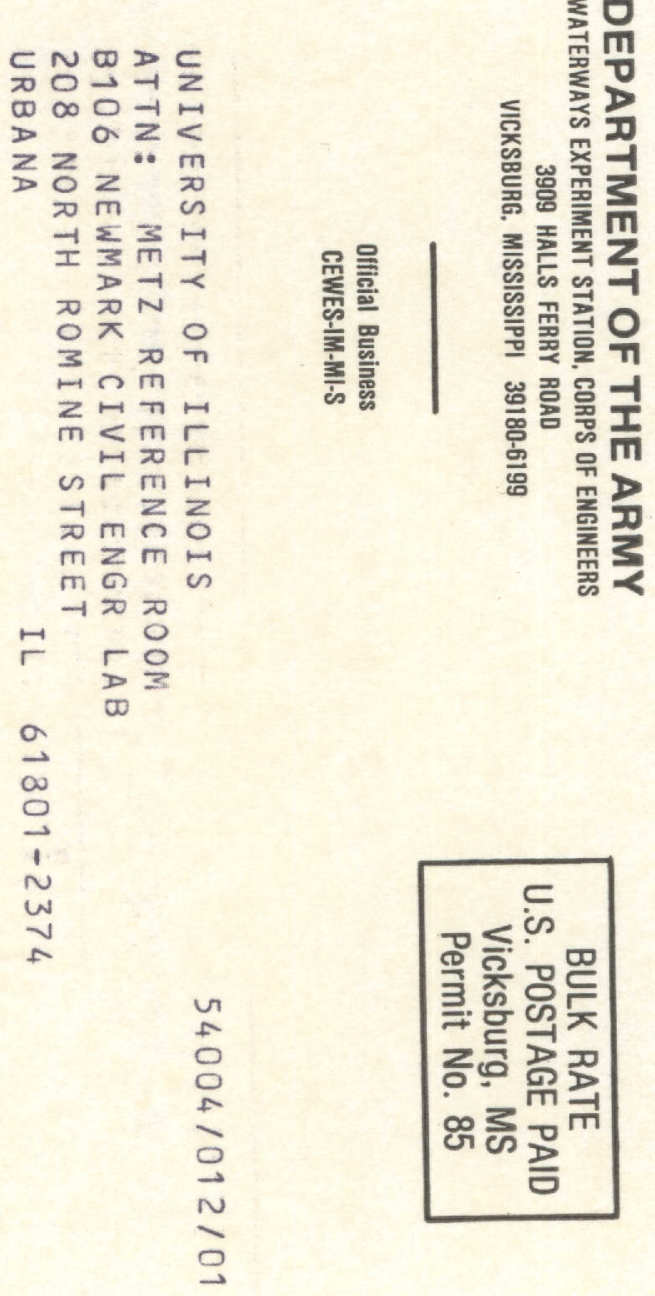

